\title{
Program Analysis Methodology Office of Transportation Technologies 2003 Quality Metrics Final Report
}

March 2002

Prepared by:

\section{OTT Analytic Team}

http://www.ott.doe.gov/facts.html

Communications

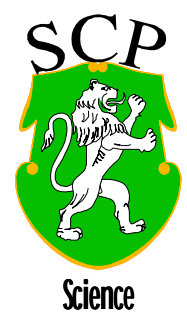

Planning

Prepared for:

Office of Transportation Technologies U.S. Department of Energy

Washington, D.C. 


\section{Table of Contents}

Table of Contents ............................................................................................................ii

List of Exhibits.................................................................................................................................

Foreword/Acknowledgement .............................................................................................................. vi

Foreword/Acknowledgement ............................................................................................................ vi

Executive Summary .................................................................................................................... vii

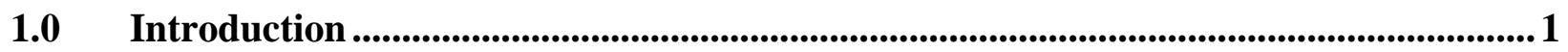

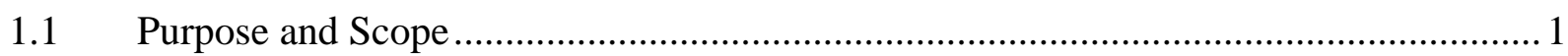

1.2 Background-The EE/RE Quality Metrics Review Process …………………............... 2

1.3 The Office of Transportation Technologies (OTT) Impacts Assessment ....................... 3

$1.4 \quad$ Report Structure/Organization............................................................................... 6

2.0 Technical Analysis Overview ……........................................................................................... 7

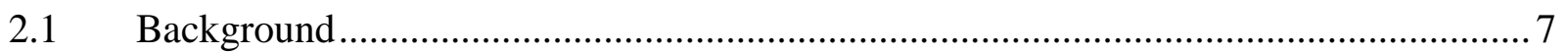

2.2 Vehicle/Technology/Fuel Baseline Assumptions ...................................................... 7

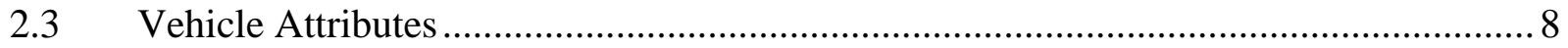

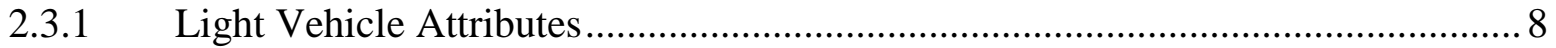

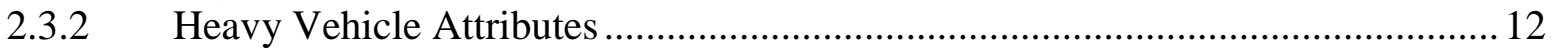

2.4 Summary of Modeling Assumptions and Structures .................................................. 13

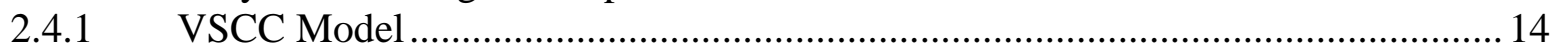

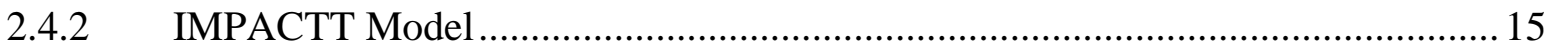

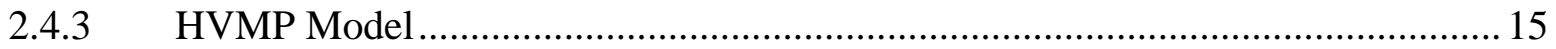

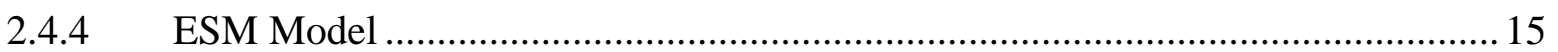

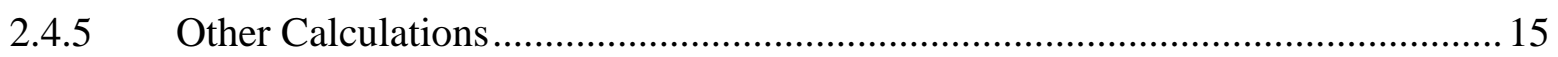

3.0 Vehicle Choice Analysis .................................................................................................. 16

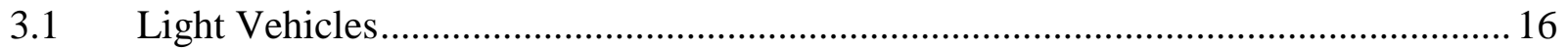

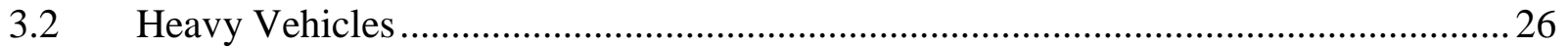

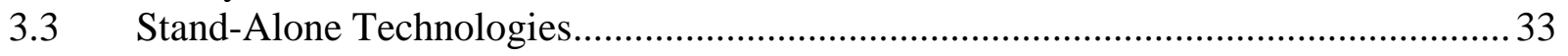

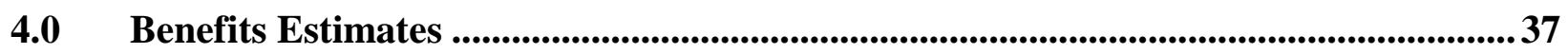

4.1 Petroleum and Other Energy Benefits Analysis ............................................................ 37

4.1.1 Biomass Assumptions ................................................................................... 38

4.1.2 Fuel Choice for Flex-Fuel Vehicles ............................................................... 40

4.1.3 Estimates of the Value of Reducing Imported Oil .............................................. 40

4.1.4. Range of Estimates of Imported Oil Premium ...................................................... 42

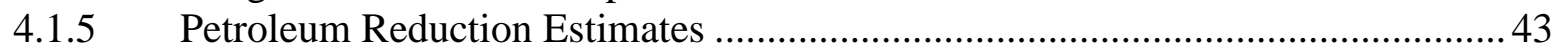

4.2 Economic and Environmental Benefits Analysis Results .............................................45

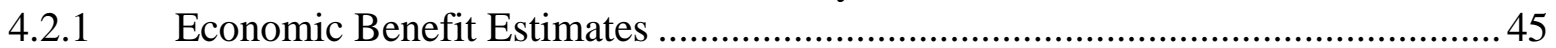

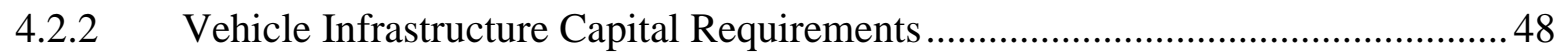

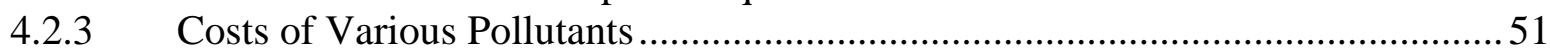

4.2.4 Aggregate Environmental Benefits Estimates..................................................53 
5.0 Accomplishments and Future Plans .....................................................................................55

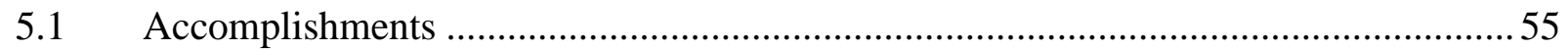

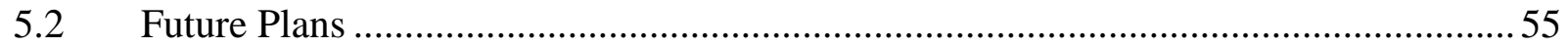

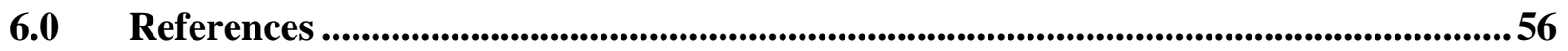

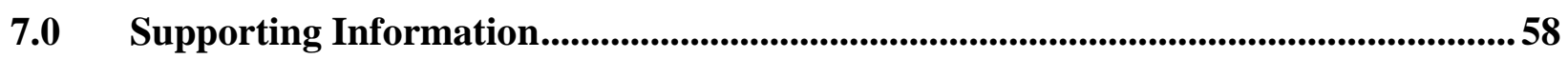

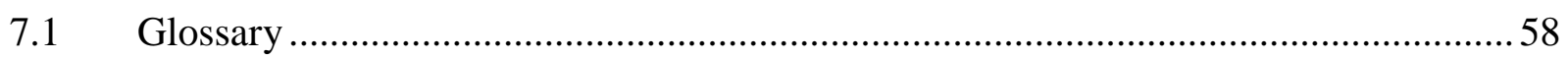

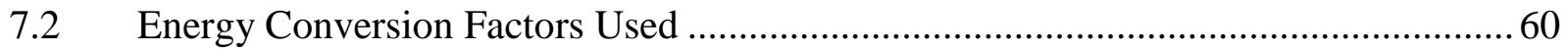

\section{Appendices}

A. Quality Metrics 2003 Results

B. Multipliers for Assessing the Economic Impacts of Investment in Advanced Vehicle Transportation Technologies 


\section{List of Exhibits}

Exhibit E-1. OTT Program Structure and QM Planning Units .............................................viii

Exhibit E-2. Vehicle/Technology Analysis Matrix ...............................................................

Exhibit E-3. QM Modeling Process ................................................................................

Exhibit E-4. Conventional Vehicle Characteristics - Large Cars (1999) ....................................xi

Exhibit E-5. Market Penetration Summary ........................................................................

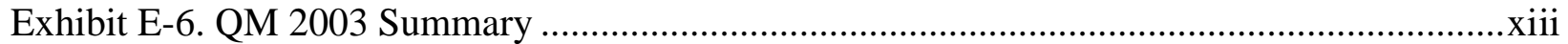

Exhibit E-6: QM 2003 Summary, Continued.......................................................................

Exhibit E-7: Transportation Petroleum Use Projection......................................................

Exhibit 1-1: Relationship Between Quality Metrics Planning Units ......................................5

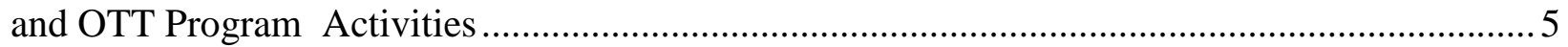

Exhibit 2-1: Conventional Baseline Vehicle Characteristics (1999) .......................................... 8

Exhibit 2-2: Technology Characteristics - Large Car (1999) ................................................... 9

Exhibit 2-3: Technology Characteristics - Small Car (1999) ................................................... 10

Exhibit 2-4: Technology Characteristics - Sport Utility Vehicle (1999).................................. 11

Exhibit 2-5: Technology Characteristics - Minivan (1999) ................................................. 11

Exhibit 2-6: Technology Characteristics - Pickup Trucks and Large Vans (1999).................... 12

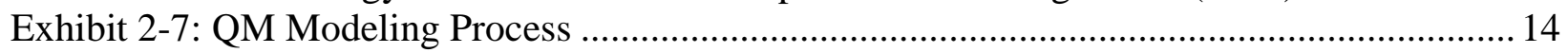

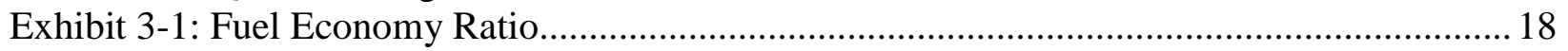

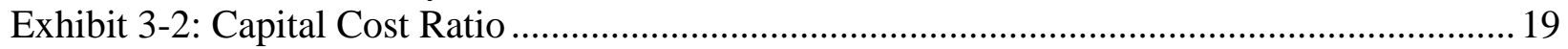

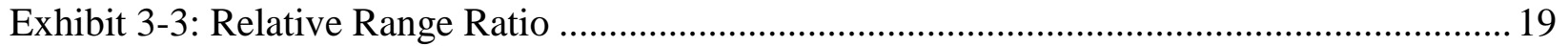

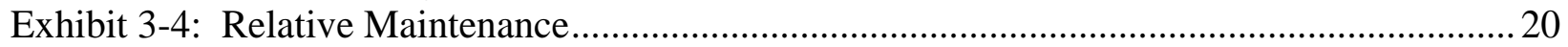

Exhibit 3-5: Market Penetration of Alternative Light Vehicles-Sales and Stocks...................... 20

Exhibit 3-6: Market Penetration of Alternative Light Vehicles-Sales .................................... 21

Exhibit 3-12: Advanced Technology Market Penetration Results by Vehicle Size Class Tabular

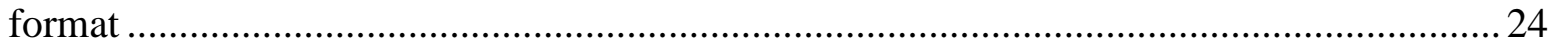

Exhibit 3-19: Medium Vehicle Travel Distribution - Central Refueling ................................ 28

Exhibit 3-20: Medium Vehicle Travel Distribution - Non-Central Refueling ............................28

Exhibit 3-21: Type 1 Heavy Vehicle Travel Distribution - Central Refueling .........................29

Exhibit 3-22: Type 1 Heavy Vehicle Travel Distribution - Non-Central Refueling ...................29

Exhibit 3-23: Type 2 Heavy Vehicle Travel Distribution - Central Refueling ........................... 30

Exhibit 3-24: Type 2 Heavy Vehicle Travel Distribution - Non-Central Refueling ....................30

Exhibit 3-25: Type 3 Heavy Vehicle Travel Distribution - Central Refueling .......................... 31

Exhibit 3-26: Type 3 Heavy Vehicle Travel Distribution - Non-Central Refueling ................... 31

Exhibit 3-30: Stand-Alone Technologies Examined........................................................... 33

Exhibit 3-31: Comparison of Stand-Alone Technology Savings with QM (Combined

Technology) Savings: Planning Unit: Vehicle Technologies R\&D Technology: Dedicated

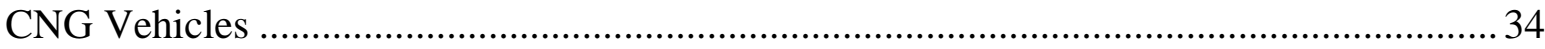

Exhibit 3-32: Comparison of Stand-Alone Technology Savings with QM (Combined

Technology) Savings: Planning Unit: Vehicle Technologies R\&D Technology: Fuel Cell

Vehicles, Gasoline-Fueled

Exhibit 3-33: Comparison of Stand-Alone Technology Savings with QM (Combined

Technology) Savings: Planning Unit: Vehicle Technologies R\&D Technology: Fuel Cell

Vehicles, Hydrogen-Fueled. 
Exhibit 3-35: Comparison of Stand-Alone Technology Savings with QM (Combined Technology) Savings: Planning Unit: Vehicle Technologies R\&D Technology: Hybrid B (3X) Vehicles

Exhibit 3-36: Comparison of Stand-Alone Technology Savings with QM (Combined

Technology) Savings: Planning Unit: All OTT Technology: All .................................... 37

Exhibit 4-3: Alternative Fuel Market Share as a Function of ................................................ 40

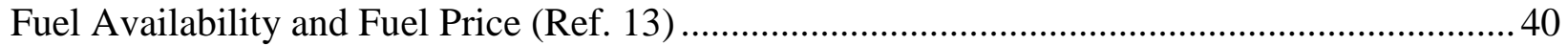

Exhibit 4-4: Value of Reducing Imported Oil (1999 \$ per Barrel) ........................................... 43

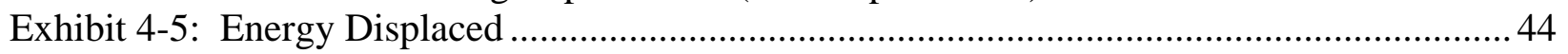

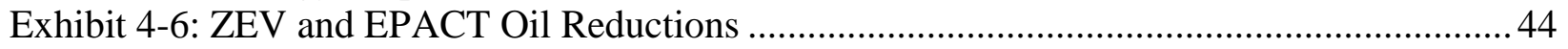

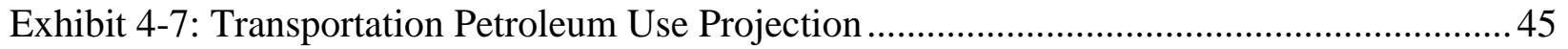

Exhibit 4-8: Employment Impacts by Sector of Economy (Jobs) .......................................... 46

Exhibit 4-9: Employment Impacts by Technology (Jobs) .................................................... 47

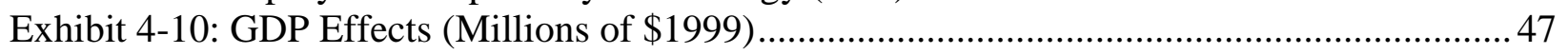

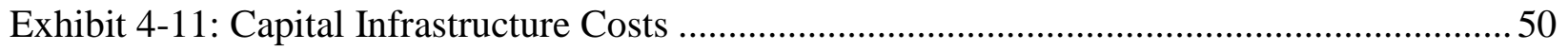

Exhibit 4-12: Aggregate Capital Expenditures ............................................................... 51

Exhibit 4-13: Range of Costs to Control $\mathrm{CO}_{2}$ Emissions .......................................................52

Exhibit 4-14: Carbon Coefficients ................................................................................... 53

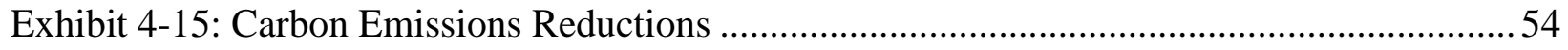




\section{Foreword/Acknowledgement}

The Analytic Team of the Office of Transportation Technologies, which prepared this report, consists of: Phil Patterson of the Office of Transportation Technologies at the U.S. Department of Energy, Jim Moore of TA Engineering, Inc. (subcontractor to Argonne National Laboratory), Margaret Singh of Argonne National Laboratory, and Elyse Steiner of the National Renewable Energy Laboratory.

Phil Patterson provided direction on all phases of this activity, and was integrally involved with the development of updates to vehicle technology characterizations. Elyse Steiner performed as the Lead Analyst for light vehicle technologies, completing numerous model runs to determine market penetrations and benefits in response to GPRA and Quality Metrics requirements. Her high quality and responsive efforts have been conducted in a manner consistent with the standards set by her predecessors in this role. Jim Moore was the Lead Analyst concerning heavy vehicle characterizations and analysis. Margaret Singh provided resourceful technical and coordination assistance with many tasks, including technology characterizations, the heavy vehicle analyses, and report reviews. Additional assistance was provided by Stacy Davis of Oak Ridge National Laboratory.

This report also reflects the efforts of many program staff analysts and researchers of the U.S. Department of Energy; Argonne National Laboratory, Center for Transportation Research; and other organizations associated with the OTT Program.

In addition, William J. Shadis, Andrew Kolonay and Irene Decker of TA Engineering provided technical and document production support for this report.

In my role as contributing analyst, and lead author for this report, I wish to express my continuing appreciation for the help of all contributors. In particular, the continuing efforts of OTT management and program staff in providing needed technical and program information are recognized.

Jim Moore

TA Engineering, Inc. 


\section{Executive Summary}

"Quality Metrics" is the analytical process for measuring and estimating future energy, environmental and economic benefits of US DOE Office of Energy Efficiency and Renewable Energy (EE/RE) programs. This report focuses on the projected benefits of the programs currently supported by the Office Of Transportation Technologies (OTT) within EE/RE. For analytical purposes, these various benefits are subdivided in terms of Planning Units which are related to the OTT program structure.

The scope of this report encompasses light vehicles including passenger automobiles and Class 1 \& 2 (light) trucks, as well as Class 3 through 8 (medium and heavy) trucks. The range of light vehicle technologies investigated include battery-electric, hybrid electric, fuel cell, advanced diesel, natural gas-fueled, and flex-fueled (using ethanol/gasoline blends). The hybrid category includes two versions, one with twice the fuel economy of conventional vehicles $(2 \mathrm{X})$ and the other with three the fuel economy $(3 \mathrm{X})$. The fuel cell category includes gasoline-fueled and hydrogen-fueled versions. A future distribution of light vehicle sizes, applications, and performance levels is calculated based on current vehicle stocks and trends, and consumer preferences. The heavy vehicle technologies investigated include tractor and trailer aerodynamic enhancements, improved bearings and lubricants, improved injectors, reduced waste heat and thermal management, fuel cell-powered auxiliaries and a diesel-electric hybrid configuration for Class 3-6 vehicles. The effects of advanced materials technologies across all vehicle types are also analyzed.

Analysis results quantify various national benefits including energy and petroleum consumption reductions, carbon emission reductions, criteria pollutant emissions reductions, and the associated economic impacts on the Gross Domestic Product (GDP) and jobs. The time focus of the analysis is from the present to the year 2030.

The programs currently conducted by OTT Offices are shown on the left side of Exhibit E-1. OTT is composed of four offices managing many separate programs. For Quality Metrics, OTT activities are aggregated into planning units based on specific program activities that are shown in the right side of Exhibit E-1.

Exhibit E-2 summarizes the specific vehicle technologies and alternative fuel that are evaluated under Quality Metrics. Five light vehicle categories and four heavy vehicle categories are considered. Each technology-vehicle category/type is analyzed separately as to when and how quickly the new technology can enter the market and its effects on energy use, the environment and the economy. All light vehicle technologies are applied to all vehicle size classes. Cost and performance differences affect consumer choices and yield different market penetration rates. In some cases there may be no consumer preference for a specific technology vehicle combination. The estimated total effect of the OTT programs is then simply the sum of the individual effects. 


\section{Exhibit E-1. OTT Program Structure and QM Planning Units}

\begin{tabular}{|c|c|}
\hline Quality Metrics Planning Unit & Related OTT Program Activities \\
\hline $\begin{array}{l}\text { Technology Deployment } \\
\text { Household CNG } \\
\text { EPAct Fleet }\end{array}$ & $\begin{array}{l}\text { Technology Utilization } \\
\text { Clean Cities } \\
\text { Testing and Evaluation } \\
\text { Energy Policy Act Replacement Fuels Program } \\
\text { Advanced Vehicle Competitions }\end{array}$ \\
\hline $\begin{array}{l}\text { Fuels Development } \\
\text { Blends and Extenders } \\
\text { Flex Fuel } \\
\text { Dedicated Conventional } \\
\text { Fuel Cell }\end{array}$ & 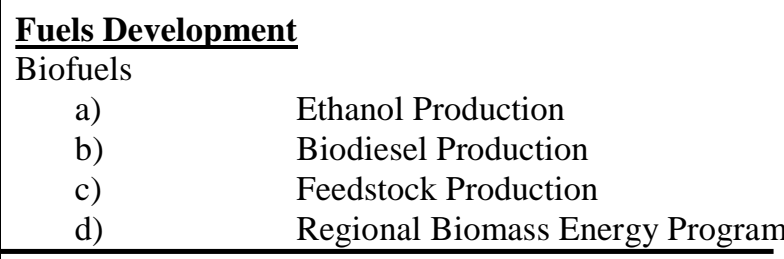 \\
\hline $\begin{array}{l}\text { Vehicle Technologies R\&D } \\
\text { Hybrid Systems R\&D } \\
\text { Fuel Cell R\&D } \\
\text { Advanced Combustion R\&D } \\
\text { Car CIDI } \\
\text { Light Truck CIDI } \\
\text { Electric Vehicles R\&D } \\
\text { Household EV } \\
\text { EPAct/ZEV Mandates } \\
\end{array}$ & 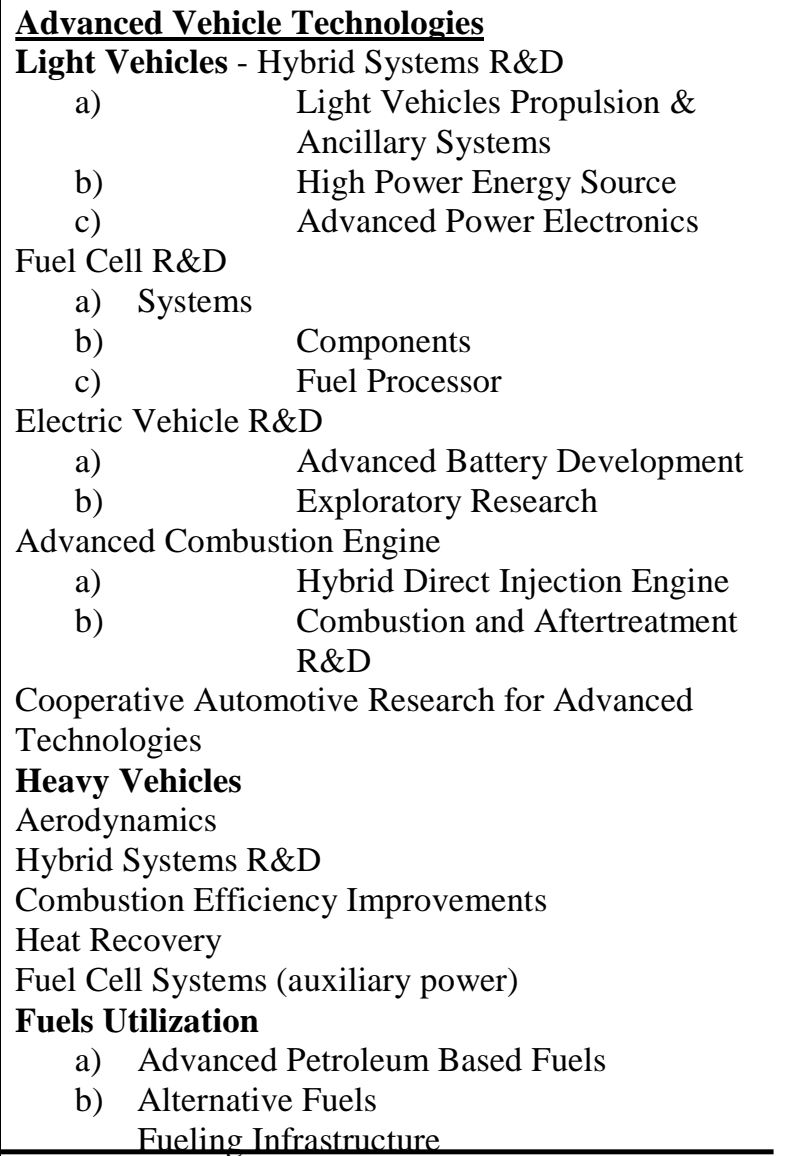 \\
\hline & $\begin{array}{l}\text { Propulsion Materials Technologies } \\
\text { Lightweight Materials Technologies } \\
\text { High Temperature Materials Laboratory }\end{array}$ \\
\hline
\end{tabular}


A variety of analytical models are used to calculate the various projected OTT Program benefits. Outputs from some of these models become inputs to some of the others. The relationships of the various models are shown in Exhibit E-3.

Exhibit E-2. Vehicle/Technology Analysis Matrix

\begin{tabular}{|c|c|c|c|c|c|}
\hline \multirow[b]{2}{*}{ Technologies } & \multicolumn{5}{|c|}{ Light Vehicles } \\
\hline & Small Cars & Large Cars & $\begin{array}{c}\text { Sport Utility } \\
\text { Vehicles }\end{array}$ & Minivans & $\begin{array}{l}\text { Pickup Trucks } \\
\text { \& Large Vans } \\
\end{array}$ \\
\hline Advanced Diesel & $x$ & $\mathrm{x}$ & $x$ & $x$ & $\mathrm{x}$ \\
\hline 2X Hybrid & $x$ & $x$ & $x$ & $x$ & $x$ \\
\hline $3 X$ Hybrid & $x$ & $x$ & $x$ & $x$ & $x$ \\
\hline Hydrogen Fuel Cell & $x$ & $x$ & $x$ & $x$ & $x$ \\
\hline Gasoline Fuel Cell & & $x$ & $x$ & $x$ & \\
\hline Electric (Battery) & $\mathrm{x}$ & $x$ & $x$ & $x$ & $x$ \\
\hline Natural Gas & $\mathrm{x}$ & $x$ & $x$ & $x$ & $\mathrm{x}$ \\
\hline Ethanol (neat, flex fuel, blends \& extenders) & $\mathrm{x}$ & $x$ & $x$ & $\mathrm{x}$ & $\mathrm{x}$ \\
\hline \multirow{2}{*}{ Technologies } & \multicolumn{5}{|c|}{ Heavy Vehicles } \\
\hline & \multicolumn{3}{|c|}{ Class 3-6 } & \multicolumn{2}{|c|}{ Class $7 \& 8$} \\
\hline Aerodynamic Enhancements & \multicolumn{3}{|c|}{$x$} & \multicolumn{2}{|c|}{$\mathrm{x}$} \\
\hline Improved Bearings/Lubes & \multicolumn{3}{|c|}{$x$} & \multicolumn{2}{|r|}{$x$} \\
\hline Improved Injectors & \multicolumn{3}{|c|}{$x$} & \multicolumn{2}{|r|}{$x$} \\
\hline Reduced Waste Heat/Thermal Management & \multicolumn{3}{|c|}{$x$} & \multicolumn{2}{|r|}{$\mathrm{x}$} \\
\hline Fuel Cell-Power Auxiliaries & & & & \multicolumn{2}{|r|}{$x$} \\
\hline Hybrid Diesel & \multicolumn{3}{|c|}{$x$} & & \\
\hline
\end{tabular}

- not included in analysis 
Exhibit E-3. QM Modeling Process

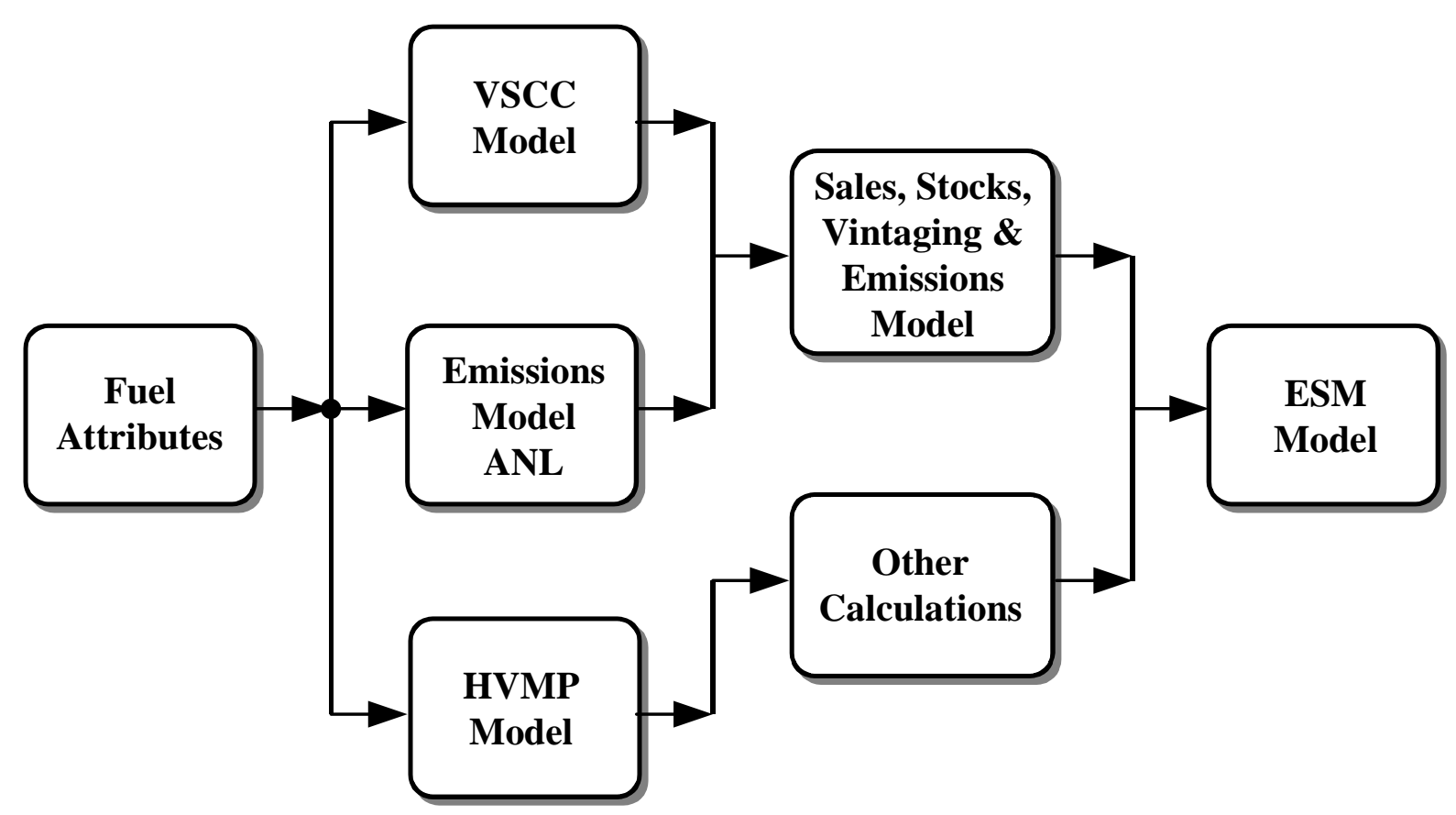

An example of the various technologies applied to one of the light vehicle categories (large cars) is shown in Exhibit E-4. Costs for conventional vehicles are in 1999 dollars. Note that the advanced technology attributes are normalized and presented as ratios to the conventional vehicle baseline attributes. These attributes form the basis for the inputs to the Vehicle Size / Consumer Choice Model (VSCC). A key output of the VSCC model is market penetrations of the technologies. The projected market penetration of the combined light vehicle technologies is shown in Exhibit E-5. Note that these technologies must not only compete with the conventional light vehicles they replace but also with each other. A separate sensitivity study was also conducted in which selected light vehicle technologies were analyzed separately against conventional light vehicles in order to measure their maximum market penetration potential. 
Exhibit E-4. Conventional Vehicle Characteristics - Large Cars (1999)

\begin{tabular}{|l|c|c|c|c|c|c|c|c|}
\hline Vehicle Technology & Status Year & $\begin{array}{c}\text { Vehicle } \\
\text { Cost } \\
\mathbf{( \$ 0 0 0 )}\end{array}$ & $\begin{array}{c}\text { Fuel } \\
\text { Economy } \\
\mathbf{( m p g )}\end{array}$ & $\begin{array}{c}\text { Relative } \\
\text { Range } \\
\text { (miles) }\end{array}$ & $\begin{array}{c}\text { Maintenance } \\
\text { Cost (\$/yr) }\end{array}$ & $\begin{array}{c}\text { Trunk } \\
\text { Space } \\
\text { (relative) }\end{array}$ & $\begin{array}{c}\text { Acceleration } \\
\text { (0-30 MPH-sec) }\end{array}$ & $\begin{array}{c}\text { Top } \\
\text { Speed } \\
\text { (MPH) }\end{array}$ \\
\hline \hline Conventional & $\mathbf{2 0 0 1}$ & $\mathbf{2 5 . 6 4}$ & $\mathbf{2 7 . 3 4}$ & $\mathbf{3 2 5}$ & $\mathbf{4 5 0}$ & $\mathbf{1 . 0 0 0}$ & $\mathbf{7 . 0}$ & $\mathbf{1 3 1 . 9}$ \\
\hline & $\mathbf{2 0 3 0}$ & $\mathbf{2 7 . 3 9}$ & $\mathbf{3 0 . 1 6}$ & $\mathbf{3 2 5}$ & $\mathbf{4 5 0}$ & $\mathbf{1 . 0 0 0}$ & $\mathbf{7 . 0}$ & $\mathbf{1 3 1 . 9}$ \\
\hline Technology Ratios ${ }^{(\mathbf{1})}$ & & & & & & & & \\
\hline Advanced Diesel & Initial-2005 & 1.07 & 1.40 & 1.20 & 1.00 & 1.00 & 1.10 & 0.80 \\
\hline Fuel Cell-Hydrogen & $\mathbf{2 0 3 0}$ & 1.05 & 1.40 & 1.20 & 1.00 & 1.00 & 1.10 & 0.80 \\
\hline & Initial-2016 & 1.40 & 2.20 & 0.90 & 1.05 & 0.80 & 1.00 & 0.72 \\
\hline Fuel Cell-Gasoline & $\mathbf{2 0 3 0}$ & 1.15 & 3.00 & 0.90 & 1.05 & 0.90 & 1.00 & 0.90 \\
\hline Initial-2008 & 1.40 & 1.90 & 1.00 & 1.05 & 1.00 & 1.00 & 0.80 \\
\hline CNG Dedicated & $\mathbf{2 0 3 0}$ & 1.20 & 2.50 & 1.00 & 0.93 & 1.00 & 1.00 & 0.80 \\
\hline Electric & Initial-2003 & 1.10 & 1.00 & 0.65 & 0.90 & 0.75 & 1.00 & 1.00 \\
\hline Hybrid (A) & $\mathbf{2 0 3 0}$ & 1.05 & 1.00 & 0.75 & 0.90 & 0.90 & 1.00 & 1.00 \\
\hline Initial-2008 & 1.90 & 4.00 & 0.36 & 0.60 & 0.50 & 1.00 & 0.60 \\
\hline Hybrid (B) & $\mathbf{2 0 3 0}$ & 1.50 & 4.00 & 0.75 & 0.60 & 0.80 & 1.00 & 0.60 \\
\hline & Initial-2005 & 1.25 & 1.50 & 1.20 & 1.05 & 0.95 & 1.00 & 0.72 \\
\hline
\end{tabular}

(1) Technology ratio = Value of parameter for the technology/Value for the conventional vehicle in the same year.

Exhibit E-5. Market Penetration Summary

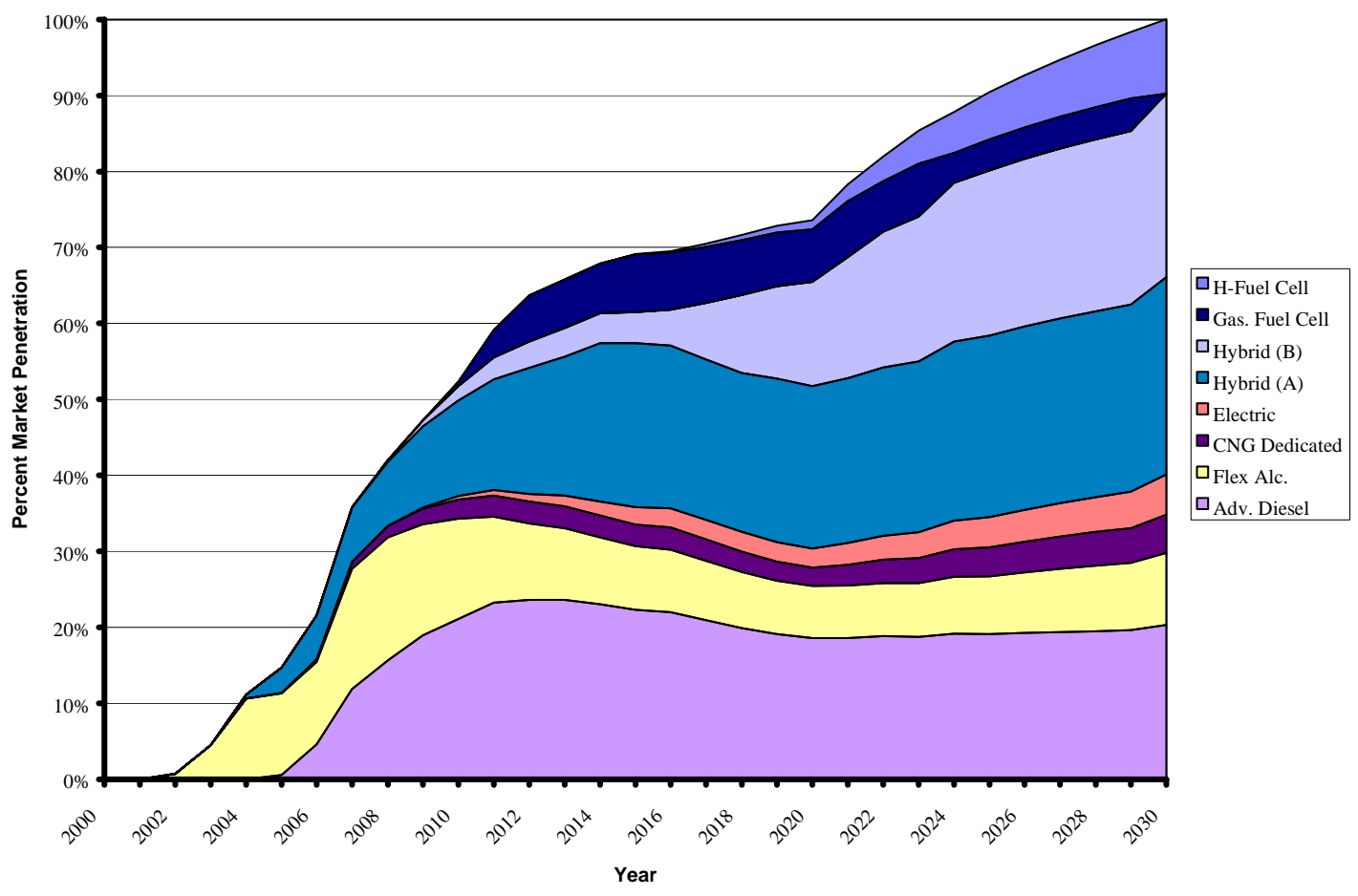


Based on the assumed vehicle technology attributes and the projected market penetrations, the energy and petroleum savings, energy cost savings and carbon emissions reductions attributable to each of the OTT Planning Units were calculated over the analysis period. This comprises the main element of the Quality Metrics reporting requirements and is shown individually and totaled in Exhibit E-6. The analysis shows that petroleum savings, expressed as Primary Oil. Carbon reductions are "end use" estimates.

Primary oil displacement, will reach 5.4 quads by 2020 and 11.6 quads by 2030 . When considered in terms of the security value to the country, these savings account for $\$ 45$ billion (1999\$) in 2020 and $\$ 134.2$ billion in 2030. The petroleum conservation results in carbon reductions of almost 92.1 million metric tons in 2020 and 204.9 million metric tons in 2030. 


\section{Exhibit E-6. QM 2003 Summary}

Primary Energy Displaced (quads)

\begin{tabular}{|c|c|c|c|c|c|c|c|c|c|c|c|c|c|c|}
\hline PLANNING UNIT & 2000 & 2005 & 2010 & 2015 & 2020 & 2025 & 2030 & 2000 & 2005 & 2010 & 2015 & 2020 & 2025 & 2030 \\
\hline Vehicle Technologies R\&D & 0.000 & 0.027 & 0.509 & 1.767 & 3.612 & 5.502 & 7.172 & 0.002 & 0.035 & 0.527 & 1.812 & 3.704 & 5.711 & 7.584 \\
\hline Hybrid Systems R\&D & 0.000 & 0.010 & 0.182 & 0.697 & 1.499 & 2.599 & 3.737 & 0.000 & 0.010 & 0.182 & 0.697 & 1.499 & 2.599 & 3.737 \\
\hline Fuel Cell R\&D & 0.000 & 0.000 & 0.002 & 0.148 & 0.368 & 0.654 & 0.954 & 0.000 & 0.000 & 0.002 & 0.148 & 0.382 & 0.748 & 1.206 \\
\hline Advanced Combustion R\&D & 0.000 & 0.001 & 0.208 & 0.573 & 0.828 & 0.910 & 0.922 & 0.000 & 0.001 & 0.208 & 0.573 & 0.828 & 0.910 & 0.922 \\
\hline Car CIDI & 0.000 & 0.001 & 0.134 & 0.339 & 0.471 & 0.497 & 0.485 & 0.000 & 0.001 & 0.134 & 0.339 & 0.471 & 0.497 & 0.485 \\
\hline Light Truck CIDI & 0.000 & 0.000 & 0.074 & 0.234 & 0.357 & 0.413 & 0.436 & 0.000 & 0.000 & 0.074 & 0.234 & 0.357 & 0.413 & 0.436 \\
\hline Electric Vehicles R\&D & 0.000 & 0.015 & 0.034 & 0.082 & 0.142 & 0.211 & 0.294 & 0.002 & 0.023 & 0.052 & 0.126 & 0.219 & 0.326 & 0.454 \\
\hline Household EV & 0.000 & 0.000 & 0.003 & 0.037 & 0.088 & 0.148 & 0.223 & 0.000 & 0.000 & 0.005 & 0.057 & 0.136 & 0.229 & 0.344 \\
\hline EPAct/ZEV Mandates & 0.000 & 0.015 & 0.030 & 0.044 & 0.054 & 0.063 & 0.071 & 0.002 & 0.023 & 0.047 & 0.069 & 0.083 & 0.097 & 0.110 \\
\hline Heavy Vehicle Systems R\&D & 0.000 & 0.001 & 0.083 & 0.268 & 0.775 & 1.128 & 1.265 & 0.000 & 0.001 & 0.083 & 0.268 & 0.775 & 1.128 & 1.265 \\
\hline Class 3-6 & 0.000 & 0.000 & 0.003 & 0.010 & 0.034 & 0.064 & 0.082 & 0.000 & 0.000 & 0.003 & 0.010 & 0.034 & 0.064 & 0.082 \\
\hline Class $7 \& 8$ & 0.000 & 0.001 & 0.080 & 0.257 & 0.741 & 1.064 & 1.183 & 0.000 & 0.001 & 0.080 & 0.257 & 0.741 & 1.064 & 1.183 \\
\hline Materials Technologies & 0.000 & 0.000 & 0.006 & 0.040 & 0.093 & 0.162 & 0.235 & 0.000 & 0.000 & 0.006 & 0.042 & 0.099 & $\mathbf{0 . 1 8 0}$ & $\overline{0.275}$ \\
\hline Propulsion System Materials & 0.000 & 0.000 & 0.000 & 0.000 & 0.000 & 0.000 & 0.000 & 0.000 & 0.000 & 0.000 & 0.000 & 0.000 & 0.000 & 0.000 \\
\hline Light Vehicle Materials & 0.000 & 0.000 & 0.006 & 0.040 & 0.093 & 0.162 & 0.235 & 0.000 & 0.000 & 0.006 & 0.042 & 0.099 & 0.180 & 0.275 \\
\hline Household EV & 0.000 & 0.000 & 0.000 & 0.004 & 0.009 & 0.014 & 0.022 & 0.000 & 0.000 & 0.000 & 0.006 & 0.013 & 0.022 & 0.033 \\
\hline Hybrid Vehicle & 0.000 & 0.000 & 0.005 & 0.020 & 0.044 & 0.076 & 0.109 & 0.000 & 0.000 & 0.005 & 0.020 & 0.044 & 0.076 & 0.109 \\
\hline Fuel Cell Vehicle & 0.000 & 0.000 & 0.000 & 0.016 & 0.040 & 0.072 & 0.105 & 0.000 & 0.000 & 0.000 & 0.016 & 0.042 & 0.082 & 0.132 \\
\hline Technology Deployment & 0.000 & 0.000 & 0.000 & 0.000 & 0.000 & 0.000 & 0.000 & 0.089 & 0.238 & 0.306 & 0.472 & 0.613 & 0.721 & $\overline{0.860}$ \\
\hline Household CNG & 0.000 & 0.000 & 0.000 & 0.000 & 0.000 & 0.000 & 0.000 & 0.000 & 0.001 & 0.077 & 0.242 & 0.376 & 0.478 & 0.611 \\
\hline EPAct Fleet & 0.000 & 0.000 & 0.000 & 0.000 & 0.000 & 0.000 & 0.000 & 0.089 & 0.237 & 0.229 & 0.230 & 0.238 & 0.243 & 0.249 \\
\hline Fuels Development & 0.000 & 0.017 & 0.169 & 0.338 & 0.973 & 1.946 & 2.919 & 0.000 & 0.017 & 0.169 & 0.338 & 0.973 & 1.946 & 2.919 \\
\hline Blends and Extenders & 0.000 & 0.013 & 0.155 & 0.317 & 0.952 & 1.363 & 1.604 & 0.000 & 0.013 & 0.155 & 0.317 & 0.952 & 1.363 & 1.604 \\
\hline Flex-Fuel & 0.000 & 0.004 & 0.014 & 0.021 & 0.021 & 0.582 & 1.314 & 0.000 & 0.004 & 0.014 & 0.021 & 0.021 & 0.582 & 1.314 \\
\hline Dedicated Conventional & 0.000 & 0.000 & 0.000 & 0.000 & 0.000 & 0.000 & 0.000 & 0.000 & 0.000 & 0.000 & 0.000 & 0.000 & 0.000 & 0.000 \\
\hline Fuel Cell & 0.000 & 0.000 & 0.000 & 0.000 & 0.000 & 0.000 & 0.000 & 0.000 & 0.000 & 0.000 & 0.000 & 0.000 & 0.000 & 0.000 \\
\hline TOTAL & $\begin{array}{l}0.000 \\
\end{array}$ & 0.044 & 0.684 & 2.146 & 4.678 & 7.610 & \begin{tabular}{|c|}
10.326 \\
\end{tabular} & 0.090 & 0.290 & 1.008 & 2.664 & 5.389 & 8.558 & $\overline{11.637}$ \\
\hline
\end{tabular}

Note:

1) Advanced Materials - metrics shown for Light Vehicle Materials are derived from percentages of total metrics estimated for Electric, Hybrid and Fuel Cell vehicles

Electric: $8.8 \%$ of total

Hybrid: $2.8 \%$ of total

Fuel Cell $9.9 \%$ of total

2) EPAct/ZEV Mandate EVs are not included in Materials Technologies Planning Unit

3) Calculations use high heating values 


\section{Exhibit E-6: QM 2003 Summary, Continued}

\begin{tabular}{|c|c|c|c|c|c|c|c|c|c|c|c|c|c|c|}
\hline \multirow[b]{2}{*}{ PLANNING UNIT } & \multicolumn{7}{|c|}{$\begin{array}{l}\text { Energy Cost Savings } \\
\text { (billions of } 1999 \text { \$'s) }\end{array}$} & \multicolumn{7}{|c|}{$\begin{array}{l}\text { Carbon Reductions } \\
\text { (million metric tons) }\end{array}$} \\
\hline & \begin{tabular}{|l}
2000 \\
\end{tabular} & 2005 & 2010 & 2015 & 2020 & 2025 & 2030 & \begin{tabular}{|l}
2000 \\
\end{tabular} & 2005 & 2010 & 2015 & 2020 & 2025 & 2030 \\
\hline Vehicle Technologies R\&D & 0.052 & 0.796 & 7.608 & 22.720 & 42.801 & $\mathbf{7 6 . 4 8 5}$ & 117.352 & 0.000 & 0.237 & 9.038 & 32.819 & 68.429 & 105.769 & 140.338 \\
\hline Hybrid Systems R\&D & 0.000 & 0.105 & 1.991 & 7.488 & 16.005 & 34.667 & 59.788 & 0.000 & 0.190 & 3.525 & 13.489 & 29.020 & 50.312 & 72.343 \\
\hline Fuel Cell R\&D & 0.000 & 0.000 & 0.025 & 1.589 & 3.779 & 8.223 & 15.262 & 0.000 & 0.000 & 0.044 & 2.865 & 7.160 & 13.488 & 21.557 \\
\hline Advanced Combustion R\&D & 0.000 & 0.023 & 3.390 & 8.743 & 12.571 & 17.233 & 20.905 & 0.000 & 0.026 & 3.694 & 10.188 & 14.742 & 16.204 & 16.415 \\
\hline Car CIDI & 0.000 & 0.016 & 2.191 & 5.170 & 7.149 & 9.419 & 11.009 & 0.000 & 0.018 & 2.387 & 6.023 & 8.382 & 8.856 & 8.644 \\
\hline Light Truck CIDI & 0.000 & 0.007 & 1.199 & 3.573 & 5.422 & 7.814 & 9.896 & 0.000 & 0.008 & 1.306 & 4.165 & 6.360 & 7.348 & 7.771 \\
\hline Electric Vehicles R\&D & 0.052 & 0.662 & 1.460 & 2.470 & 3.470 & 6.208 & 10.009 & 0.000 & 0.006 & 0.119 & 0.918 & 2.009 & 3.208 & 4.720 \\
\hline Household EV & 0.000 & 0.000 & 0.036 & 0.427 & 1.008 & 2.310 & 4.395 & 0.000 & 0.000 & 0.064 & 0.756 & 1.763 & 2.922 & 4.395 \\
\hline EPAct/ZEV Mandates & 0.052 & 0.662 & 1.424 & 2.043 & 2.462 & 3.897 & 5.613 & 0.000 & 0.006 & 0.055 & 0.162 & 0.246 & 0.286 & 0.326 \\
\hline Heavy Vehicle Systems R\&D & 0.000 & 0.006 & 0.742 & 2.431 & 6.976 & 10.153 & 11.389 & 0.000 & 0.014 & 1.656 & 5.359 & 15.498 & 22.557 & 25.303 \\
\hline Class 3-6 & 0.000 & 0.000 & 0.023 & 0.095 & 0.305 & 0.574 & 0.741 & 0.000 & 0.000 & 0.052 & 0.210 & 0.677 & 1.275 & 1.647 \\
\hline Class $7 \& 8$ & 0.000 & 0.006 & 0.719 & 2.336 & 6.671 & 9.580 & 10.648 & 0.000 & 0.014 & 1.605 & 5.149 & 14.821 & 21.282 & 23.655 \\
\hline Materials Technologies & 0.000 & 0.003 & 0.064 & 0.434 & 0.979 & 2.136 & 3.842 & 0.000 & 0.006 & 0.114 & 0.781 & 1.802 & 3.229 & 4.900 \\
\hline Propulsion System Materials & 0.000 & 0.000 & 0.000 & 0.000 & 0.000 & 0.000 & 0.000 & 0.000 & 0.000 & 0.000 & 0.000 & 0.000 & 0.000 & 0.000 \\
\hline Light Vehicle Materials & 0.000 & 0.003 & 0.064 & 0.434 & 0.979 & 2.136 & 3.842 & 0.000 & 0.006 & 0.114 & 0.781 & 1.802 & 3.229 & 4.900 \\
\hline Household EV & 0.000 & 0.000 & 0.004 & 0.041 & 0.097 & 0.223 & 0.424 & 0.000 & 0.000 & 0.006 & 0.073 & 0.170 & 0.282 & 0.424 \\
\hline Hybrid Vehicle & 0.000 & 0.003 & 0.058 & 0.218 & 0.466 & 1.010 & 1.741 & 0.000 & 0.006 & 0.103 & 0.393 & 0.845 & 1.465 & 2.107 \\
\hline Fuel Cell Vehicle & 0.000 & 0.000 & 0.003 & 0.175 & 0.415 & 0.904 & 1.677 & 0.000 & 0.000 & 0.005 & 0.315 & 0.787 & 1.482 & 2.369 \\
\hline Technology Deployment & 0.004 & 0.090 & 0.389 & 0.913 & 1.287 & 3.514 & 6.503 & 0.588 & 1.723 & 2.050 & 2.865 & 3.575 & 4.115 & 4.803 \\
\hline Household CNG & 0.000 & 0.003 & 0.300 & 0.865 & 1.260 & 2.804 & 5.116 & 0.000 & 0.003 & 0.377 & 1.181 & 1.838 & 2.337 & 2.987 \\
\hline EPAct Fleet & 0.004 & 0.087 & 0.090 & 0.048 & 0.027 & 0.711 & 1.387 & 0.588 & 1.720 & 1.673 & 1.684 & 1.737 & 1.778 & 1.816 \\
\hline Fuels Development & 0.000 & -0.004 & -0.016 & -0.023 & -0.022 & 1.340 & 6.520 & 0.000 & 0.318 & 3.185 & 6.355 & 18.269 & 36.539 & 54.809 \\
\hline Blends and Extenders & 0.000 & 0.000 & 0.000 & 0.000 & 0.000 & 0.000 & 0.000 & 0.000 & 0.245 & 2.918 & 5.953 & 17.874 & 25.601 & 30.124 \\
\hline Flex-Fuel & 0.000 & -0.004 & -0.016 & -0.023 & -0.022 & 1.340 & 6.520 & 0.000 & 0.073 & 0.267 & 0.402 & 0.395 & 10.939 & 24.685 \\
\hline Fuel Cell & 0.000 & 0.000 & 0.000 & 0.000 & 0.000 & 0.000 & 0.000 & 0.000 & 0.000 & 0.000 & 0.000 & 0.000 & 0.000 & 0.000 \\
\hline TOTAL & 0.056 & 0.885 & 8.046 & 24.044 & 45.044 & 83.475 & 134.217 & 0.588 & 2.284 & 14.386 & 42.819 & 92.075 & 149.652 & 204.850 \\
\hline
\end{tabular}

Note:

1) Advanced Materials - metrics shown for Light Vehicle Materials are derived from percentages of total metrics estimated for Electric, Hybrid and Fuel Cell vehicles

Electric: $8.8 \%$ of total

Hybrid: $2.8 \%$ of total

Fuel Cell $9.9 \%$ of total

2) EPAct/ZEV Mandate EVs are not included in Materials Technologies Planning Unit

3) Calculations use high heating values 
The projected effect of the OTT program on U.S. transportation system energy use is shown in Exhibit E-7. The petroleum "Gap" is defined here as the difference between transportation energy use and domestic petroleum production. In the baseline case, note that the gap approaches 13 million barrels per day by Year 2030. The OTT program impact is projected to reduce this shortfall by nearly 5 million barrels per day, or about thirty-eight percent $(38 \%)$. About two thirds of this reduction is in the form of efficiency improvements. The remaining third is obtained via substitution of non-petroleum energy sources.

\section{Exhibit E-7: Transportation Petroleum Use Projection}

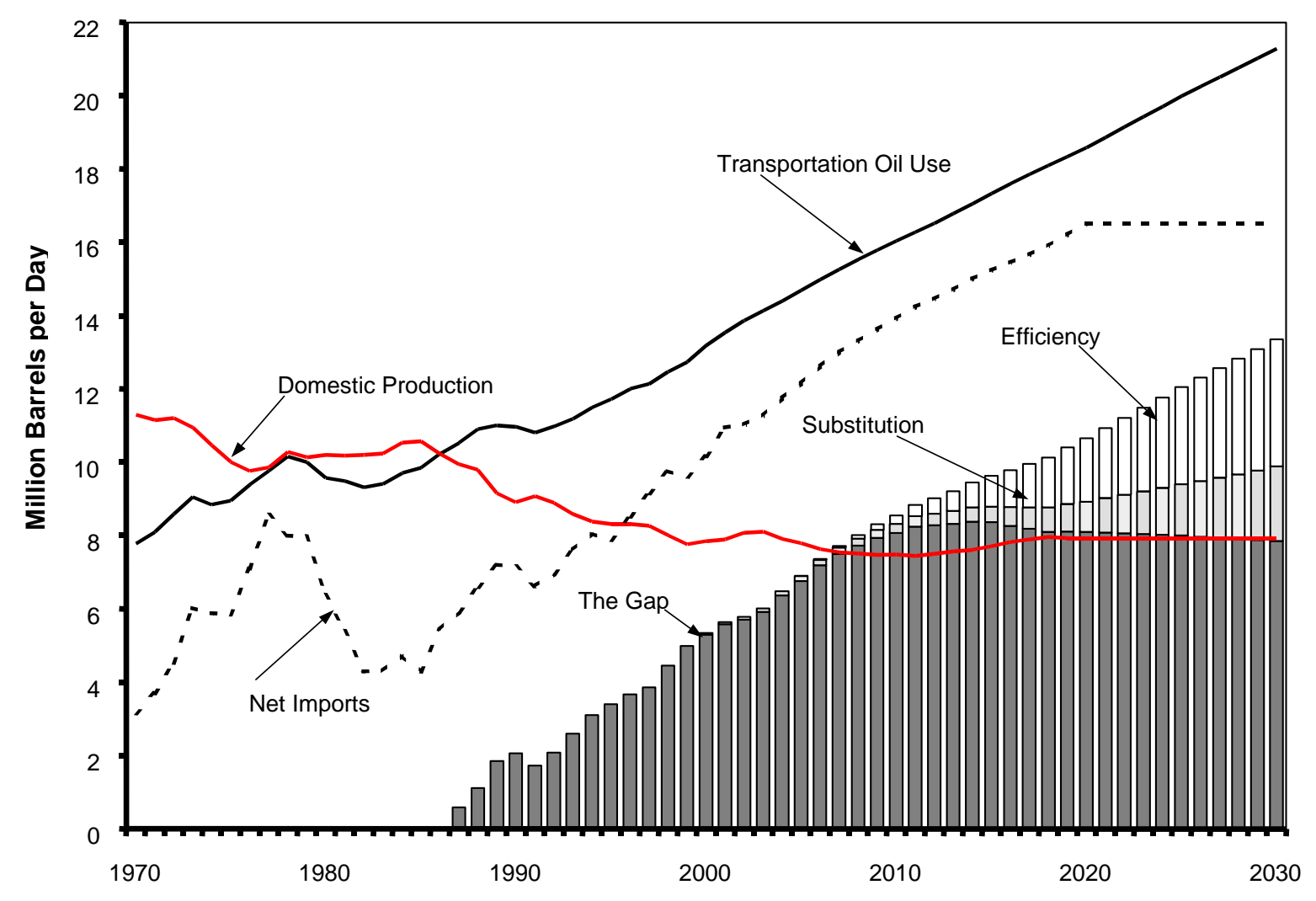




\subsection{Introduction}

\section{$1.1 \quad$ Purpose and Scope}

The purpose of this report is to describe the methodology and results obtained from a continuing DOE Office of Transportation Technologies (OTT) activity to estimate future effects of OTT projects on national energy use, petroleum consumption, criteria emissions, greenhouse gas emissions, and various measures of national income and employment. Assumptions are made about the future costs and characteristics of alternative vehicles and fuels. Models that take into account the value that vehicle buyers place on various vehicle characteristics are used to estimate the market penetration of new vehicle technologies. A different set of assumptions would yield results that are different from what is presented here. Analysis results quantify various benefits including:

- energy and petroleum reductions,

- carbon equivalent greenhouse gas emissions,

- criteria pollutant emissions reductions,

- and the associated economic impacts on the Gross Domestic Product (GDP) and jobs.

The scope of this report addresses light vehicles including passenger automobiles, Class $1 \& 2$ trucks, and heavy trucks (Classes 3 through 8). The time period spans the present through the year 2030. All energy savings start from baseline projections of transportation sector energy use obtained from the "Annual Energy Outlook," issued annually by the US Department of Energy, Energy Information Administration (Ref. 1). This analysis is based on conventional vehicle fuel economy and purchase price as designated for the "Large Car" in the EIA Annual Energy Outlook, although the other characteristics of the large car and of the other vehicle types have been generated from other sources.

The range of light vehicle technologies investigated includes battery electric, hybrid, fuel cell, advanced compression ignition direct injection (CIDI), and natural gas-fueled, prime movers. Both conventional automotive fuels (gasoline and diesel fuel) and unconventional fuels (bioderived fuels, natural gas and hydrogen) are investigated. A representative distribution of light vehicle sizes, applications, and performance levels is postulated based on current and projected vehicle stocks and trends. The heavy vehicle technologies investigated include aerodynamic improvements, combustion system efficiency improvements; and hybrid-diesel and fuel cell auxiliary power plants. The advanced light and heavy vehicle technologies are projected to become mature and have market penetrations that grow significantly over the next three decades.

This report meets two programmatic purposes. First, it constitutes the OTT final documentation for the Quality Metrics 2003 (QM 2003) analytical process of the DOE Office of Energy Efficiency and Renewable Energy (EE/RE). Quality Metrics has been an annual DOE EE/RE-wide analysis and review procedure since 1995. QM seeks to monitor and measure the impacts of all DOE EE/RE programs and to summarize their overall national effects. The Quality Metrics process is described in more detail in Section 1.2 below. 
Second, this report serves as an internal OTT program management tool. This report was initially developed to meet the reporting requirements set forth in the EPACT 2021 Report to Congress in 1992 and has been since updated annually for internal reporting and management purposes. This dual purpose led OTT to the development of the analysis methodology, designated OTT Impacts Assessment, described in Section 1.3 below.

The report updates also reflect annual changes in the DOE/EIA Annual Energy Outlook; and in OTT program structure, goals and milestones. Each publication includes projections for the budget year identified in the report title. This specific issue is named Quality Metrics 2003 because the impacts and benefits are consistent with the FY 2003 budget report to Congress. Using the Annual Energy Outlook for 2001 for the baseline context of the analysis is consistent with the basis of development for the FY 2003 budget request.

\subsection{Background-The EE/RE Quality Metrics Review Process}

The Quality Metrics program of EE/RE and the preparation of the EPACT 2021 report to Congress led to the development of an impacts assessment methodology for the Office of Transportation Technologies (OTT), which is continually improved and updated. Within OTT, the QM methodology is applied to four major functions. Each function relates to an element of the transportation system associated with one or more of the technologies addressed by the OTT organizational structure.

Each major function is further subdivided into Planning Units that are separately analyzed. An element may be a specific technology or a separate transportation sector or both. The total energy savings and emissions reductions attributable to OTT programs is equal to the sum of the savings from each of these separate elements. Planning Units are similar, but not identical to the OTT program structure. The OTT Quality Metrics Functions and Planning Units are listed and described below:

1. Technology Deployment: This area includes OTT projects that involve moving new technologies into the public and private sectors. These include: EPAct Fleet Mandates and penetration of CNG vehicles in the household market.

2. Fuels Development: This area involves the development of transportation system technologies to make use of some of the more promising fuels that may substitute for gasoline in the future. These currently include biomass-based ethanol used in flexiblefuel vehicles and utilized in fuel blends.

3. Vehicle Technologies R\&D: This area includes all light and heavy vehicle technologies currently supported in OTT that are intended to increase engine efficiency or reduce parasitic losses and that result in higher vehicle fuel economy in concert with lower criteria and greenhouse gas emissions. Currently, this includes Light Vehicles (cars and Class 1 and 2 trucks) and Heavy Vehicle Technologies (Classes 3-6, 7 \& 8) as follows:

- Fuel Cell R\&D: Gasoline- and hydrogen-fueled vehicles with 2.5 times to 3.0 times conventional vehicle fuel economy (mature technology, varying with vehicle category). 
- Hybrid Vehicle R\&D: Gasoline fueled, with 2.0 to 3.0 times conventional vehicle fuel economy (mature technology, varying with vehicle category). The hybrid vehicles analyzed are assumed to be grid-independent (no net electric grid consumption).

- Light Vehicle Engine R\&D: Compression Ignition Direct Injection (CIDI) vehicles with 1.4 times conventional fuel economy.

- Electric Battery Vehicle R\&D, including Zero Emission Vehicle (ZEV) mandates.

- Heavy Vehicle Technologies: Fuel cells for auxiliary power, hybrid vehicles and various efficiency improvements.

4. Materials Technologies: This area deals with more fundamental issues concerning the use of advanced materials in light and heavy vehicles. Some of these (such as ceramics) promise higher engine efficiencies while others reduce the weight of a vehicle's structure and hence increase fuel economy. The planning units include the following project areas:

- Light vehicle materials for electric, hybrid, and fuel cell vehicles, and

- Heavy vehicle materials.

It is assumed that the electric, hybrid, and fuel cell vehicle technologies will require the use of light weight materials to achieve program goals for fuel efficiency.

Prior Quality Metrics (QM 2002) analyses and results are described in Reference 2. The Analytic Team has continued to improve the modeling process with improved market penetration modeling. For QM 2003, the number and designation of light vehicle classes was maintained at five (5) as shown below:

1. Small Cars (all other EPA size classes; $<110 \mathrm{ft}^{3}$ of passenger and luggage volume, e.g., Nissan Altima and smaller);

2. Large Cars (EPA size classes Large and Midsize; $110 \mathrm{ft}^{3}$ of passenger and luggage volume and larger, e.g., Dodge Stratus and larger). The Large Car designation used here shares common fuel economy and cost assumptions with the conventional vehicle AEO Large Car designation.

3. Minivans

4. Sport Utility Vehicles and;

5. Pickup Trucks and Large Vans (Cargo Trucks).

It is the intent of this analysis that these vehicle classes be utilized as building blocks to produce a reasonable simulation of the current and projected light vehicle fleet in the U.S. over the next three decades.

\subsection{The Office of Transportation Technologies (OTT) Impacts Assessment}

The OTT seeks to develop and promote advanced highway transportation vehicles, systems and alternative fuel use technologies that lead to reduced imported oil, lower regulated emissions and 
reduced emission of atmospheric gases that may add to the greenhouse effect. To these ends, OTT develops partnerships with elements of the domestic transportation industry and private and public research and development organizations.

The analytic impacts methodology is referred to as "OTT Impacts Assessment." The scope of the OTT Impacts Assessment contains analyses that supplement those required by QM. These include:

- Comprehensive end-use criteria and carbon pollutant reductions; i.e. all criteria pollutants generated at end use, as well as carbon emissions that contribute to global warming and climate change. This compares to Quality Metrics, which is limited to assessing the following emissions: $\mathrm{CO}_{2}$ equivalent, hydrocarbons, $\mathrm{CO}$, and $\mathrm{NO}_{\mathrm{x}}$ reduction benefits only;

- Gross Domestic Product/Jobs (in the QM process, macroeconomic effects attributable to the OTT Planning Units are determined by others); and

- Cost analyses, including the capital/infrastructure estimates, and oil security cost valuations.

The relationship between the various OTT Program Elements and the Quality Metrics Planning Units is shown in Exhibit 1-1 below.

The Quality Metrics and OTT Impacts Assessment are conducted using the Reference Case projections of the Energy Information Administration to define the world energy market characteristics, U.S. energy consumption by economic sector and energy prices. The reader is referred to Publication DOE/EIA-0383 (2001), "Annual Energy Outlook 2001, With Projections to 2020" (Ref. 1). The current version of this report is available at the following website address: http://www.eia.doe.gov/bookshelf.html. (Go to the Forecasting subsection of the Library Archives section. Current and past AEO reports can be downloaded from this location). AEO 2001 results are used as this version was the most recent available when the analyses were conducted. AEO 2001 also provides the context for the FY 2003 budget request, which provides the programmatic basis for the Quality Metrics evaluations.

A number of scenarios are formulated and analyzed in executing the OTT Impacts methodology. Such impacts estimates are needed to accompany each annual budget submission, with final estimates prepared at the end of each calendar year. 


\section{Exhibit 1-1: Relationship Between Quality Metrics Planning Units and OTT Program Activities}

\begin{tabular}{|c|c|}
\hline Quality Metrics Planning Unit & Related OTT Program Activities \\
\hline $\begin{array}{l}\text { Technology Deployment } \\
\text { Household CNG } \\
\text { EPAct Fleet }\end{array}$ & $\begin{array}{l}\text { Technology Utilization } \\
\text { Clean Cities } \\
\text { Testing and Evaluation } \\
\text { Energy Policy Act Replacement Fuels Program } \\
\text { Advanced Vehicle Competitions }\end{array}$ \\
\hline $\begin{array}{l}\text { Fuels Development } \\
\text { Blends and Extenders } \\
\text { Flex Fuel } \\
\text { Dedicated Conventional } \\
\text { Fuel Cell }\end{array}$ & \begin{tabular}{cl}
\multicolumn{2}{l}{ Fuels Development } \\
Biofuels & \\
a) & Ethanol Production \\
b) & Biodiesel Production \\
c) & Feedstock Production \\
d) & Regional Biomass Energy Program
\end{tabular} \\
\hline $\begin{array}{l}\text { Vehicle Technologies R\&D } \\
\text { Hybrid Systems R\&D } \\
\text { Fuel Cell R\&D } \\
\text { Advanced Combustion R\&D } \\
\text { Car CIDI } \\
\text { Light Truck CIDI } \\
\text { Electric Vehicles R\&D } \\
\text { Household EV } \\
\text { EPAct/ZEV Mandates }\end{array}$ & $\begin{array}{l}\text { Advanced Vehicle Technologies } \\
\text { Light Vehicles - Hybrid Systems R\&D } \\
\text { a) Light Vehicles Propulsion \& Ancillary } \\
\text { Sys. } \\
\text { b) High Power Energy Storage } \\
\text { c) Advanced Power Electronics } \\
\text { Fuel Cell R\&D } \\
\text { a) Systems } \\
\text { b) Components } \\
\text { c) Fuel Processor } \\
\text { Electric Vehicle R\&D } \\
\text { a) Advanced Battery Development } \\
\text { b) Exploratory Research } \\
\text { Advanced Combustion Engine } \\
\text { a) Hybrid Direct Injection Engine } \\
\text { b) Combustion and Aftertreatment R\&D } \\
\text { Cooperative Automotive Research For Advanced } \\
\text { Technologies } \\
\text { Heavy Vehicles } \\
\text { Aerodynamics } \\
\text { Hybrid Systems R\&D } \\
\text { Combustion Efficiency Improvements } \\
\text { Heat Recovery } \\
\text { Fuel Cell Systems (auxiliary power) } \\
\text { Fuels Utilization } \\
\text { a) Advanced Petroleum Based Fuels } \\
\text { b) Alternative Fuels } \\
\end{array}$ \\
\hline Materials Technologies & $\begin{array}{l}\text { Propulsion Materials Technologies } \\
\text { Lightweight Materials Technologies } \\
\text { High Temperature Materials Laboratory }\end{array}$ \\
\hline
\end{tabular}


In addition to this report, other assessments of transportation and fuels technologies relevant to the OTT program have been made. For example, Birky, et al, "Future U.S. Highway Energy Use: A Fifty Year Perspective DRAFT”, May 3, 2001 (Ref. 3). This report evaluates the potential effects on petroleum demand by 2050 of six alternative scenarios involving various combinations of energy conserving and alternative fuels technology.

OTT also continues to evaluate consumer attitudes toward transportation alternatives, and alternative fuels program strategy options. A description of the Office of Transportation Technology as well as the results of many DOE OTT analytical efforts are also available on the Internet at http://www.ott.doe.gov/facts.html.

\subsection{Report Structure/Organization}

This report consists of seven principal sections. An overview of the technical analysis process is described in Section 2. Section 3 contains a description of the vehicle choice analysis simulation tools and results. As noted above, the QM 2003 analytical scope includes heavy as well as light vehicles. Section 4 discusses the analysis results in terms of energy and petroleum reductions, environmental and economic benefits, and also includes a benefit/cost analysis of OTT programs. Accomplishments and future plans are discussed in Section 5. References and supporting information including a glossary of technical terms and acronyms as well as energy unit conversion factors follow in Sections 6 and 7, respectively. Where available, website addresses for references are included.

Detailed results of the Quality Metrics analyses are presented in Appendix A. Results contained in this Appendix include:

- QM 2003 benefits summary by Planning Unit (Tables A-1 \& A-7),

- GPRA Inputs and Analytical Results (Tables A-3 to A-6),

- Market Penetration Estimates - percentages and numbers of vehicles sold and in use in the fleet (Tables A-9 to A-14, A-16),

- Energy benefits - gasoline displaced, biofuels demand, EPAct fuel use, ZEV and EPACT electricity use (Tables A-8, A-15 to A-20),

- Transportation Energy Prices (Table A-21),

- Emissions impacts - carbon, $\mathrm{NO}_{\mathrm{x}}, \mathrm{CO}$, and $\mathrm{HC}$ reductions in both physical units and dollars (Tables A-22 to A-29),

- Cost effects - vehicle purchase, aggregate consumer investment, and corporate expenditures (Tables A-30 to A-33),

- Light Vehicle Fuel Economy Projections (Table A-34) and,

- Medium and Heavy Truck Results (Tables A-35 \& A-36).

Appendix B is a paper by Jeffry M. Fang on economic multipliers to be used in assessing advanced vehicle technologies. This work provided the basis for the discussions of economic effects presented in Section 4. 


\subsection{Technical Analysis Overview}

\subsection{Background}

The analysis process involves the following four activities:

1) Definition of vehicle characteristics for advanced technologies;

2) Market penetration analysis estimated by vehicle size class;

3) Energy savings, petroleum displacement, environmental and economic benefits quantification via motive source and vehicle efficiency improvements and alternative fuel use; and

4) Development of summary documentation.

The time frame for the study spans the present to 2030 .

\subsection{Vehicle/Technology/Fuel Baseline Assumptions}

The fuel and vehicle characteristics can be considered in three categories: fuel attributes, light vehicle attributes and heavy vehicle attributes. These attributes are defined by program staff and are subjected to external peer review. All of these vehicle attributes are tracked since they have been identified as pertinent variables in people's vehicle purchase decisions. The light and heavy conventional vehicle attributes used in this analysis are presented in Exhibit 2-1. Note that there are five classes of light vehicles and two "class groupings" of heavy vehicles (Classes 3-6 and Classes $7 \& 8$ ) with three market segments of Class $7 \& 8$ vehicles. Heavy vehicle costs are in the form of incremental costs and are discussed in Section 3.2. 
Exhibit 2-1: Conventional Baseline Vehicle Characteristics (1999)

\begin{tabular}{|l|c|c|c|c|c|}
\hline \multicolumn{1}{|c|}{ Vehicle Category } & $\begin{array}{c}\text { Market } \\
\text { Segement }\end{array}$ & $\begin{array}{c}\text { Fuel Economy } \\
\text { (MPG) }\end{array}$ & $\begin{array}{c}\text { Acceleration } \\
\mathbf{0 - 3 0 ~ M P H} \\
\text { (seconds) }\end{array}$ & $\begin{array}{c}\text { Top Speed } \\
\text { (MPH) }\end{array}$ & $\begin{array}{c}\text { Vehicle Cost } \\
\mathbf{( \$ )}\end{array}$ \\
\hline Light Vehicles & & & & & \\
\hline Large Car & All & 27.3 & 6.0 & 131.9 & $\$ 25,640$ \\
\hline Small Car & All & 31.4 & 7.0 & 121.1 & $\$ 19,520$ \\
\hline Sport Utility Vehicle & All & 20.5 & 7.0 & 108.3 & $\$ 27,140$ \\
\hline Minivan & All & 26.2 & 7.0 & 108.3 & $\$ 24,950$ \\
\hline Pickup Truck \& Large Van & All & 21.6 & 7.0 & 122.0 & $\$ 20,140$ \\
\hline Heavy Vehicles & & & & & - \\
\hline Calss 3-6 Trucks & All & 7.9 & - & - & See Sect. 3.2 \\
\hline Class 7\&8 Trucks & Type 1 & 4.5 & - & - & See Sect. 3.2 \\
\hline Class 7\&8 Trucks & Type 2 & 6.1 & - & & See Sect. 3.2 \\
\hline Class 7\&8 Trucks & Type 3 & 7.7 & - & See Sect. 3.2 \\
\hline
\end{tabular}

1. Gasoline Equivalent-yr 2001 technology

2. All prices are in $\$ 1999$

\subsection{Vehicle Attributes}

\subsubsection{Light Vehicle Attributes}

The five classes of light vehicles areas follows:

- Small Car

- Large Car

- Minivan

- Sport Utility Vehicle

- Pickup Truck/Large Van.

Seven technology options were investigated for light vehicles:

\section{Light Vehicle Attributes:}

- Advanced Diesel-Compression Ignition/Direct Injection (CIDI-Diesel)

- Electric (battery)

- Flex Fuel (gasoline/ethanol) 
- Hybrid-Electric (battery/gasoline-two times the fuel economy of conventional vehicles ${ }^{1}$

- Hybrid-Electric (battery/gasoline-three times the fuel economy of conventional vehicles $^{(1)}$

- Fuel Cell: gasoline-fueled

- Fuel Cell: hydrogen-fueled

- Natural Gas-Fueled

The vehicle attributes summaries for the five light vehicle classes are indicated in Exhibits 2-2 through 2-6. The year of introduction, attribute ratios at the year of introduction and the ratios at maturity are shown.

Conventional vehicle attributes are projected to change with time. For example, purchase price is expected to escalate in real terms (See Appendix Table A-30). The reference year for conventional vehicles attributes is 1999. Fuel economy values are assumed to be "Combined Cycle" values (fifty-five percent (55\%) City Cycle and forty-five percent (45\%) Highway Cycle per EPA emissions certification test data).

Exhibit 2-2: Technology Characteristics - Large Car (1999)

\begin{tabular}{|l|c|c|c|c|c|c|c|c|}
\hline Vehicle Technology & Status Year & $\begin{array}{c}\text { Vehicle } \\
\text { Cost } \\
(\mathbf{\$ 0 0 0})\end{array}$ & $\begin{array}{c}\text { Fuel } \\
\text { Economy } \\
(\mathbf{m p g})\end{array}$ & $\begin{array}{c}\text { Relative } \\
\text { Range } \\
\text { (miles) }\end{array}$ & $\begin{array}{c}\text { Maintenance } \\
\text { Cost (\$/yr) }\end{array}$ & $\begin{array}{c}\text { Trunk } \\
\text { Space } \\
\text { (relative) }\end{array}$ & $\begin{array}{c}\text { Acceleration; } \\
\mathbf{0 - 3 0} \text { MPH } \\
\text { (sec) }\end{array}$ & $\begin{array}{c}\text { Top } \\
\text { Speed } \\
\text { (MPH) }\end{array}$ \\
\hline \hline Conventional & $\mathbf{2 0 0 1}$ & $\mathbf{2 5 . 6 4}$ & $\mathbf{2 7 . 3 4}$ & $\mathbf{3 2 5}$ & $\mathbf{4 5 0}$ & $\mathbf{1 . 0 0 0}$ & $\mathbf{7 . 0}$ & $\mathbf{1 3 1 . 9}$ \\
\hline & $\mathbf{2 0 3 0}$ & $\mathbf{2 7 . 3 9}$ & $\mathbf{3 0 . 1 6}$ & $\mathbf{3 2 5}$ & $\mathbf{4 5 0}$ & $\mathbf{1 . 0 0 0}$ & $\mathbf{7 . 0}$ & $\mathbf{1 3 1 . 9}$ \\
\hline Technology Ratios (1) & & & & & & & & \\
\hline Advanced Diesel & Initial-2005 & 1.07 & 1.40 & 1.20 & 1.00 & 1.00 & 1.10 & 0.80 \\
\hline Fuel Cell-Hydrogen & $\mathbf{2 0 3 0}$ & 1.05 & 1.40 & 1.20 & 1.00 & 1.00 & 1.10 & 0.80 \\
\hline Fuel Cell-Gasoline & Initial-2016 & 1.40 & 2.20 & 0.90 & 1.05 & 0.80 & 1.00 & 0.72 \\
\hline CNG Dedicated & $\mathbf{2 0 3 0}$ & 1.15 & 3.00 & 0.90 & 1.05 & 0.90 & 1.00 & 0.90 \\
\hline Initial-2008 & $\mathbf{2 0 3 0}$ & 1.40 & 1.90 & 1.00 & 1.05 & 1.00 & 1.00 & 0.80 \\
\hline Electric & Initial-2003 & 1.10 & 1.00 & 0.65 & 0.90 & 0.75 & 1.00 & 0.80 \\
\hline Hybrid (A) & $\mathbf{2 0 3 0}$ & 1.05 & 1.00 & 0.75 & 0.90 & 0.90 & 1.00 & 1.00 \\
\hline Hybrid (B) & $\mathbf{I n i t i a l - 2 0 0 8}$ & 1.90 & 4.00 & 0.36 & 0.60 & 0.50 & 1.00 & 0.60 \\
\hline & $\mathbf{2 0 3 0}$ & 1.50 & 4.00 & 0.75 & 0.60 & 0.80 & 1.00 & 0.60 \\
\hline
\end{tabular}

(1) Technology ratio = Value of parameter for the technology/Value for the conventional vehicle in the same year.

\footnotetext{
${ }^{1}$ The two HEV light vehicle configurations postulated are assumed to achieve two and three times the fuel economy of conventional vehicle of the same class and vintage. The relative fuel economy of the vehicles achieving twice the fuel economy (Hybrid A) and three times the fuel economy (Hybrid B) increases gradually and reaches the full effect only upon "maturity". 
Exhibit 2-3: Technology Characteristics - Small Car (1999)

\begin{tabular}{||l|c|c|c|c|c|c|c|c|}
\hline Vehicle Technology & Status Year & $\begin{array}{c}\text { Vehicle } \\
\text { Cost } \\
(\mathbf{\$ 0 0 0})\end{array}$ & $\begin{array}{c}\text { Fuel } \\
\text { Economy } \\
(\mathbf{m p q})\end{array}$ & $\begin{array}{c}\text { Relative } \\
\text { Range } \\
\text { (miles) }\end{array}$ & $\begin{array}{c}\text { Maintenance } \\
\text { Cost (\$/yr) }\end{array}$ & $\begin{array}{c}\text { Trunk } \\
\text { Space } \\
\text { (relative) }\end{array}$ & $\begin{array}{c}\text { Acceleration; } \\
\mathbf{0 - 3 0} \mathbf{M P H} \\
\text { (sec) }\end{array}$ & $\begin{array}{c}\text { Top } \\
\text { Speed } \\
\text { (MPH) }\end{array}$ \\
\hline \hline Conventional & $\mathbf{2 0 0 1}$ & $\mathbf{1 9 . 5 2}$ & $\mathbf{3 1 . 4 1}$ & $\mathbf{3 7 2}$ & $\mathbf{4 0 0}$ & $\mathbf{1}$ & $\mathbf{7 . 0}$ & $\mathbf{1 2 1 . 1}$ \\
\hline & $\mathbf{2 0 3 0}$ & $\mathbf{2 1 . 2 1}$ & $\mathbf{3 4 . 4 1}$ & $\mathbf{3 7 2}$ & $\mathbf{4 0 0}$ & $\mathbf{1}$ & $\mathbf{7 . 0}$ & $\mathbf{1 2 1 . 1}$ \\
\hline Technology Ratios(1) & & & & & & & & \\
\hline Advanced Diesel & Initial-2004 & 1.07 & 1.35 & 1.20 & 1.00 & 1.00 & 1.10 & 0.85 \\
\hline Fuel Cell-Hydrogen & $\mathbf{2 0 3 0}$ & 1.07 & 1.35 & 1.20 & 1.00 & 1.00 & 1.10 & 0.85 \\
\hline Initial-2018 & 1.35 & 2.50 & 0.75 & 1.05 & 0.90 & 1.10 & 0.90 \\
\hline CNG Dedicated & $\mathbf{2 0 3 0}$ & 1.15 & 3.00 & 0.75 & 0.93 & 0.90 & 1.10 & 0.90 \\
\hline Electric & Initial-2003 & 1.10 & 1.00 & 0.66 & 0.90 & 0.75 & 1.00 & 1.00 \\
\hline Hybrid (A) & $\mathbf{2 0 3 0}$ & 1.10 & 1.00 & 0.66 & 0.90 & 0.90 & 1.00 & 1.00 \\
\hline Initial-2003 & 2.70 & 4.00 & 0.33 & 0.60 & 0.80 & 1.00 & 0.60 \\
\hline Hybrid (B) & $\mathbf{2 0 3 0}$ & 1.50 & 4.00 & 0.40 & 0.60 & 0.80 & 1.00 & 0.60 \\
\hline & Initial-2003 & 1.33 & 1.25 & 1.00 & 1.05 & 0.90 & 0.90 & 0.64 \\
\hline
\end{tabular}

(1) Technology ratio = Value of parameter for the technology/Value for the conventional vehicle in the same year. 
Exhibit 2-4: Technology Characteristics - Sport Utility Vehicle (1999)

\begin{tabular}{|c|c|c|c|c|c|c|c|c|}
\hline Vehicle Technology & Status Year & $\begin{array}{c}\text { Vehicle } \\
\text { Cost } \\
(\$ 000) \\
\end{array}$ & $\begin{array}{c}\begin{array}{c}\text { Fuel } \\
\text { Economy } \\
\text { (mpg) }\end{array} \\
\end{array}$ & $\begin{array}{c}\text { Relative } \\
\text { Range } \\
\text { (miles) } \\
\end{array}$ & $\begin{array}{c}\text { Maintenance } \\
\text { Cost }(\$ / y r)\end{array}$ & $\begin{array}{c}\text { Trunk } \\
\text { Space } \\
\text { (relative) } \\
\end{array}$ & $\begin{array}{c}\text { Acceleration; } \\
\text { 0-30 MPH } \\
\text { (sec) } \\
\end{array}$ & $\begin{array}{c}\text { Top } \\
\text { Speed } \\
\text { (MPH) } \\
\end{array}$ \\
\hline \multirow[t]{2}{*}{ Conventional } & 2001 & 27.14 & 20.50 & 300 & 450 & 1 & 7.0 & 108.3 \\
\hline & 2030 & 28.69 & 23.31 & 300 & 450 & 1 & 7.0 & 108.3 \\
\hline \multicolumn{9}{|l|}{ Technology Ratios $^{(1)}$} \\
\hline \multirow[t]{2}{*}{ Advanced Diesel } & Initial-2004 & 1.075 & 1.40 & 1.20 & 1.00 & 1.00 & 1.10 & 0.90 \\
\hline & 2030 & 1.07 & 1.40 & 1.20 & 1.00 & 1.00 & 1.10 & 0.90 \\
\hline \multirow[t]{2}{*}{ Fuel Cell-Hydrogen } & Initial-2012 & 1.40 & 2.00 & 0.90 & 1.05 & 0.90 & 1.10 & 0.90 \\
\hline & 2030 & 1.15 & 3.00 & 0.90 & 0.93 & 0.90 & 1.10 & 0.90 \\
\hline \multirow[t]{2}{*}{ Fuel Cell-Gasoline } & Initial-2008 & 1.40 & 1.75 & 1.00 & 1.05 & 1.00 & 1.00 & 1.00 \\
\hline & End- 2023 & 1.20 & 2.00 & 1.00 & 0.93 & 1.00 & 1.00 & 1.00 \\
\hline \multirow[t]{2}{*}{ CNG Dedicated } & Initial-2005 & 1.05 & 1.00 & 0.75 & 0.90 & 0.90 & 1.00 & 1.00 \\
\hline & 2030 & 1.05 & 1.00 & 0.75 & 0.90 & 1.00 & 1.00 & 1.00 \\
\hline \multirow[t]{2}{*}{ Electric } & Initial-2010 & 1.50 & 4.00 & 0.60 & 0.60 & 1.00 & 1.00 & 0.60 \\
\hline & 2030 & 1.40 & 4.00 & 0.60 & 0.60 & 1.00 & 1.00 & 0.60 \\
\hline \multirow[t]{2}{*}{ Hybrid (A) } & Initial-2003 & 1.25 & 1.25 & 1.00 & 1.05 & 1.00 & 0.90 & 0.75 \\
\hline & 2030 & 1.05 & 2.00 & 1.00 & 0.98 & 1.00 & 0.90 & 0.90 \\
\hline \multirow[t]{2}{*}{ Hybrid (B) } & Initial-2013 & 1.30 & 1.90 & 1.00 & 1.05 & 0.90 & 0.90 & 0.90 \\
\hline & 2030 & 1.10 & 3.00 & 1.00 & 0.93 & 0.90 & 0.90 & 0.90 \\
\hline
\end{tabular}

(1) Technology ratio = Value of parameter for the technology/Value for the conventional vehicle in the same year.

Exhibit 2-5: Technology Characteristics - Minivan (1999)

\begin{tabular}{|c|c|c|c|c|c|c|c|c|}
\hline Vehicle Technology & Status Year & $\begin{array}{c}\text { Vehicle } \\
\text { Cost } \\
(\$ 000)\end{array}$ & $\begin{array}{c}\begin{array}{c}\text { Fuel } \\
\text { Economy } \\
(\mathrm{mpg})\end{array} \\
\end{array}$ & $\begin{array}{c}\begin{array}{c}\text { Relative } \\
\text { Range } \\
\text { (miles) }\end{array} \\
\end{array}$ & $\begin{array}{c}\text { Maintenance } \\
\text { Cost }(\$ / y r)\end{array}$ & \begin{tabular}{|c|} 
Trunk \\
Space \\
(relative) \\
\end{tabular} & $\begin{array}{c}\text { Acceleration; } \\
\text { 0-30 MPH } \\
\text { (sec) }\end{array}$ & $\begin{array}{l}\text { Top } \\
\text { Speed } \\
\text { (MPH) }\end{array}$ \\
\hline \multirow[t]{2}{*}{ Conventional } & 2000 & 24.95 & 26.23 & 350 & 450 & 1 & 7.0 & 108.3 \\
\hline & 2030 & 26.41 & 28.78 & 372 & 450 & 1 & 7.0 & 108.3 \\
\hline \multicolumn{9}{|l|}{ Technology Ratios $^{(1)}$} \\
\hline \multirow[t]{2}{*}{ Advanced Diesel } & Initial-2006 & 1.075 & 1.40 & 1.20 & 1.00 & 1.00 & 1.10 & 0.80 \\
\hline & 2030 & 1.07 & 1.40 & 1.20 & 1.00 & 1.00 & 1.10 & 0.80 \\
\hline \multirow[t]{2}{*}{ Fuel Cell-Hydrogen } & Initial-2014 & 1.35 & 2.00 & 0.90 & 1.10 & 0.90 & 1.10 & 0.90 \\
\hline & 2030 & 1.15 & 3.00 & 0.90 & 0.95 & 0.90 & 1.10 & 0.90 \\
\hline \multirow[t]{2}{*}{ Fuel Cell-Gasoline } & Initial-2008 & 1.35 & 1.75 & 1.00 & 1.00 & 1.00 & 1.00 & 1.00 \\
\hline & End-2021 & 1.20 & 2.50 & 1.00 & 1.00 & 1.00 & 1.00 & 1.00 \\
\hline \multirow[t]{2}{*}{ CNG Dedicated } & Initial-2005 & 1.05 & 1.00 & 0.75 & 0.90 & 0.90 & 1.00 & 1.00 \\
\hline & 2030 & 1.05 & 1.00 & 0.75 & 0.90 & 1.00 & 1.00 & 1.00 \\
\hline \multirow[t]{2}{*}{ Electric } & Initial-2008 & 1.90 & 4.00 & 0.38 & 0.60 & 1.00 & 1.00 & 0.60 \\
\hline & 2030 & 1.50 & 4.00 & 0.60 & 0.60 & 1.00 & 1.00 & 0.60 \\
\hline \multirow[t]{2}{*}{ Hybrid (A) } & Initial-2007 & 1.25 & 1.50 & 1.00 & 1.05 & 1.00 & 0.90 & 0.75 \\
\hline & 2030 & 1.05 & 2.00 & 1.00 & 0.98 & 1.00 & 0.90 & 0.90 \\
\hline \multirow[t]{2}{*}{ Hybrid (B) } & Initial-2014 & 1.25 & 2.00 & 1.00 & 1.10 & 0.90 & 0.90 & 0.90 \\
\hline & 2030 & 1.10 & 3.00 & 1.00 & 0.95 & 0.90 & 0.90 & 0.90 \\
\hline
\end{tabular}


Exhibit 2-6: Technology Characteristics - Pickup Trucks and Large Vans (1999)

\begin{tabular}{|c|c|c|c|c|c|c|c|c|}
\hline Vehicle Technology & Status Year & $\begin{array}{c}\text { Vehicle } \\
\text { Cost } \\
(\$ 000) \\
\end{array}$ & \begin{tabular}{|c|} 
Fuel \\
Economy \\
$(\mathrm{mpg})$
\end{tabular} & $\begin{array}{c}\begin{array}{c}\text { Relative } \\
\text { Range } \\
\text { (miles) }\end{array} \\
\end{array}$ & $\begin{array}{c}\text { Maintenance } \\
\text { Cost }(\$ / y r)\end{array}$ & \begin{tabular}{|c|} 
Trunk \\
Space \\
(relative)
\end{tabular} & $\begin{array}{c}\text { Acceleration; } \\
0-30 \mathrm{MPH} \\
\text { (sec) }\end{array}$ & $\begin{array}{l}\text { Top } \\
\text { Speed } \\
\text { (MPH) }\end{array}$ \\
\hline \multirow[t]{2}{*}{ Conventional } & 2001 & 20.14 & 21.62 & 350 & 500 & 1 & 7.0 & 122 \\
\hline & 2030 & 21,5 & 24.16 & 350 & 500 & 1 & 7.0 & 122 \\
\hline \multicolumn{9}{|l|}{ Technology Ratios $^{(1)}$} \\
\hline \multirow[t]{2}{*}{ Advanced Diesel } & Initial-2003 & 1.10 & 1.40 & 1.20 & 1.00 & 1.00 & 1.10 & 1.00 \\
\hline & 2030 & 1.07 & 1.40 & 1.20 & 1.00 & 1.00 & 1.10 & 1.00 \\
\hline \multirow[t]{2}{*}{ Fuel Cell-Hydrogen } & Initial-2012 & 1.35 & 2.00 & 0.90 & 1.05 & 0.80 & 1.00 & 0.90 \\
\hline & 2030 & 1.15 & 3.00 & 0.90 & 0.93 & 0.85 & 1.00 & 0.90 \\
\hline \multirow[t]{2}{*}{ CNG Dedicated } & Initial-2003 & 1.10 & 1.00 & 0.75 & 0.90 & 1.00 & 1.00 & 1.00 \\
\hline & 2030 & 1.10 & 1.00 & 0.75 & 0.90 & 1.00 & 1.00 & 1.00 \\
\hline \multirow[t]{2}{*}{ Electric } & Initial-2005 & 2.70 & 4.00 & 0.33 & 0.60 & 1.00 & 1.00 & 0.60 \\
\hline & 2030 & 1.50 & 4.00 & 0.33 & 0.60 & 1.00 & 1.00 & 0.60 \\
\hline \multirow[t]{2}{*}{ Hybrid (A) } & Initial-2008 & 1.20 & 1.60 & 1.00 & 1.05 & 1.00 & 1.00 & 0.90 \\
\hline & 2030 & 1.05 & 2.00 & 1.00 & 0.98 & 1.00 & 1.00 & 0.90 \\
\hline \multirow[t]{2}{*}{ Hybrid (B) } & Initial-2016 & 1.25 & 2.00 & 0.80 & 1.05 & 0.80 & 1.00 & 0.90 \\
\hline & 2030 & 1.10 & 3.00 & 0.80 & 0.93 & 0.85 & 1.00 & 0.90 \\
\hline
\end{tabular}

(1) Technology ratio = Value of parameter for the technology/Value for the conventional vehicle in the same year.

Changes in attributes can be assumed to occur non-linearly during the analysis period; e.g. significant improvements may occur shortly after introduction with lesser changes occurring in later years. In some cases, the technology may be assumed to be commercially mature from the time when it is introduced to the vehicle class.

As Exhibits 2-2 through 2-6 indicate, in some cases, technology characteristics also vary among the size classes both for conventional gasoline and alternative technologies.

\subsubsection{Heavy Vehicle Attributes}

The six heavy vehicle classes (standard DOT Classes 3 through 8) are divided into two groups and three market segments that differ from each other with respect to end use, average fuel economy and average annual miles traveled.

- Class 3-6 Trucks (10,000 - 26,000 lbs. gross vehicle weight (GVW)

- $\quad$ Class $7 \& 8$ Trucks (26,001 lbs. And greater GVW)

Three market segments of Class $7 \& 8$ trucks have been identified.

- Type 1 - multi-stop, step van, beverage, utility, winch, crane, wrecker, logging, pipe, refuse collection, dump, and concrete delivery;

- Type 2 - platform, livestock, auto transport, oil-field, grain, and tank;

- Type 3 - refrigerated van, drop frame van, open top van, and basic enclosed van. 
Heavy Vehicle Technologies:

- Aerodynamic improvements (various techniques)

- Reduced rolling resistance (various techniques)

- Improved efficiency transmissions

- Advanced technology accessories (water pumps, air compressors, heating and airconditioning, etc.)

- Advanced Diesel Engines (improved combustion, waste heat management, reduced friction)

This is discussed in more detail in Section 3.2 - Heavy Vehicles.

\subsection{Summary of Modeling Assumptions and Structures}

The modeling process is illustrated in Exhibit 2-7. The vehicle attributes for the advanced technologies are input into the vehicle choice model and emissions models. The light Vehicle Size / Consumer Choice (VSCC) model then estimates market penetration by size class. The emissions model estimates the end-use emissions on a grams per mile basis for each technology. For light vehicles, the market penetrations and emissions rates are then input into a model that is based on the Integrated Market Penetration and Anticipated Cost of Transportation Technologies, or IMPACTT, the vehicle stock/energy/emission model. Finally, energy and vehicle stock information is input into the economic model to estimate GDP and jobs impacts.

The heavy vehicle choice model estimates market penetration by market class. For heavy vehicles, the market penetrations are used to calculate benefits, then energy and vehicle stock information is input into the economic model to estimate GDP and jobs impacts. 
Exhibit 2-7: QM Modeling Process

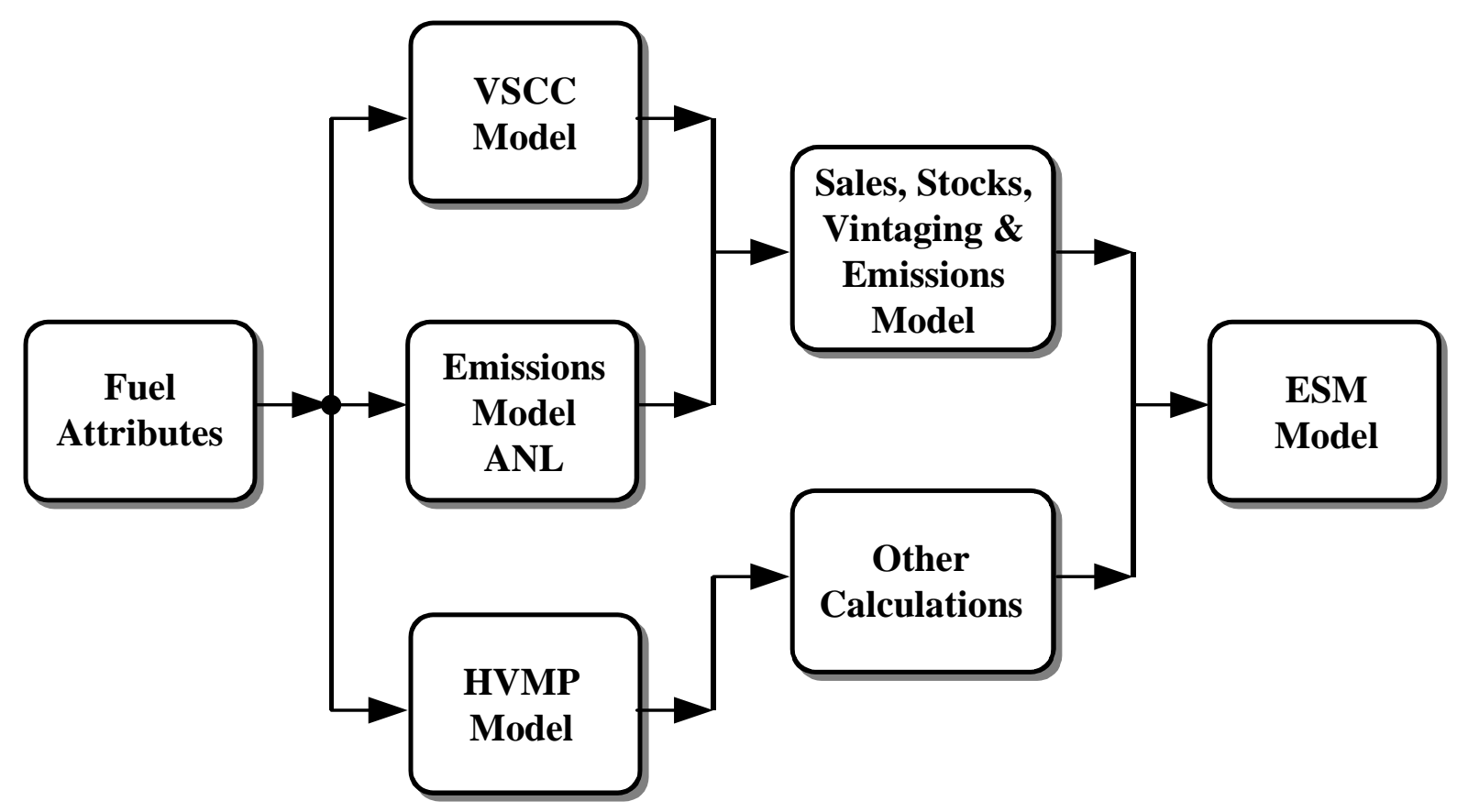

\subsubsection{VSCC Model}

Vehicle Size/Consumer Choice Model

The VSCC Model is an Excel-based spreadsheet model that predicts the future market penetration of light vehicles with new technologies based on the measured or estimated attributes of those technologies such as cost, fuel economy, range, and maintenance cost. The model also calculates alternative fuel consumption and incremental costs borne by purchasers of advanced technology vehicles.

\section{Inputs:}

The model, as now operated, has a universe of five (5) light vehicle types/sizes: large car, small car, sport utility vehicle, minivan and pickup truck/large van. It includes seven (7) technology groupings: conventional (gasoline-fueled, spark ignition), direct-injected Diesel-fueled (CIDI, electric, hybrid-electric ( $2 X \& 3 X)$, fuel cell (gasoline and hydrogen-fueled), and compressed natural gas fueled (conventional spark ignition). More technologies could be added.

The choice among technologies is made by a logit model that has influence coefficients determined in a national survey (Ref. 3). The model includes influence coefficients for purchase price, range, maintenance cost, 0-30 $\mathrm{mph}$ acceleration time, top speed, luggage space, fuel cost $(\$ / \mathrm{mi})$, whether home refueling is available, whether multiple fuels are available, whether or not the vehicle can use gasoline and the range. In addition, fuel-specific factors and alternative fuel 
availability are part of the evaluation process. A more detailed discussion of the VSCC Model can be found in Section 3.1

\subsubsection{IMPACTT Model}

Integrated Market Penetration and Anticipated Cost of Transportation Technologies

The IMPACTT model is a spreadsheet model developed by Marianne Mintz of Argonne National Laboratory that calculates the effects of advanced-technology vehicles and market penetration on baseline fuel use and emissions. For QM analysis purposes, it has been modified to accept the market penetration data output from the VSCC model and determine the vehicle stock and miles traveled as a function of time for each technology. In addition, it calculates fuel use and emissions reduction effects.

\subsubsection{HVMP Model}

The Heavy Vehicle Market Penetration Model serves the same purpose as the VSCC model except that it applies to potential market impacts of new technologies in the medium and heavy truck transportation sectors. This sector is subdivided into two categories with classes $7 \& 8$ further disaggregated into 3 types according to application characteristics that yield substantially different fuel economies and annual travel characteristics based on 1997 VIUS survey data. Historical market penetration data for energy conservation technologies were used to calibrate the model. Cost effectiveness of the energy conservation investment is considered a prime determinant in its introduction and growth rate. A more detailed discussion of the HVMP Model can be found in Section 3.2.

\subsubsection{ESM Model}

The Economic Spreadsheet Model developed by NREL calculates the employment effects of the OTT programs by industry sector for each OTT technology.

A more detailed discussion of the ESM Model can be found in Section 4.2.1.

\subsubsection{Other Calculations}

As required, off-line market penetration and benefits analysis is required. Examples are ZEVs and alternative fuel vehicles commercialized under EPAct "Fleet" provisions. In addition to the above models and calculations, infrastructure incremental capital requirements for the vehicle manufacturing industry and aggregate energy cost reductions from OTT technologies also are estimated. 


\subsection{Vehicle Choice Analysis}

Vehicle choice analysis is used to develop market penetration estimates of advanced technology and alternative fuel vehicles. These market penetrations provide the basis for estimating the future energy, environmental, and economic benefits associated with OTT programs. A model to estimate consumer behavior has been developed and is described below. Market penetration results are also discussed in this section.

\subsection{Light Vehicles}

The Vehicle Size/Consumer Choice (VSCC) model was developed to define the successful introduction of technologies in light vehicles by vehicle size class. This modeling exercise acknowledges that the introduction of advanced technologies is a gradual one. The VSCC model is a discrete choice, multi-attribute logit model designed to simulate the household market for alternative-fuel light vehicles. Light vehicle fleet purchase decisions are assumed to be similar to the household market. Subsequent analyses will account for any observed differences between household and fleet preferences as the needed data become available. The model forecasts, through the year 2030, the future sales of conventional and alternatively fueled light vehicles by size class, technology and fuel type. Market penetration estimates are based on consumer-derived utilities related to vehicle attributes that are associated with the different alternative fuels and advanced propulsion technologies. As such, the model is "household" based. Other market sectors are considered in various "off-line" calculations.

The vehicle demand function used in this model is based on the utility-maximization theory in which the consumer demand for alternative vehicles is defined as a function of the attributes of these vehicles and the fuels they use. The total utility of each light vehicle technology and fuel makeup is determined by the sum of the attribute utilities of that vehicle for each size class. The size class market share penetration estimates for the different technologies are a function of each technology's total utility compared to the total utility of other vehicles and technologies in that size class. The technology's total utility is calculated by summing attribute input values that have been multiplied by their corresponding coefficient

The attributes of conventional and alternative vehicle technologies were defined for five vehicle classes:

- small car

- large car

- minivan

- $\quad$ sport utility vehicle

- pickup and large van. 
Technologies considered include:

- Conventional—spark ignition, gasoline. This baseline technology is assumed to improve slightly through technological innovation and weight reductions to yield a fuel economy improvement of about ten percent (10\%) by the year 2030 compared to 2000.

- Advanced Diesel-compression-ignition, direct-injection (CIDI) - which offers at least a thirty-five percent (35\%) fuel economy improvement with the same tailpipe emissions as conventional gasoline vehicles of the same year. This emissions performance assumption is significant, given historical experience that diesel engines pollute more than comparable gasoline-fueled, spark ignition engines.

- Hybrid-Electric - grid-independent, parallel or series configuration. Two hybrid versions are considered " $\mathrm{A}$ " and " $\mathrm{B}$ ", which achieve " $2 \mathrm{X}$ " and " $3 \mathrm{X}$ " fuel economy benefits by 2030 compared to conventional vehicles

- Fuel cell - proton exchange membrane, capable of being fueled with gasoline, ethanol or hydrogen. Currently, gasoline and hydrogen fuel cell vehicles are modeled. Additional fuel cell fueling options are periodically considered.

- Natural gas - spark ignition-powered vehicle, similar to Conventional, but fueled with natural gas (CNG Dedicated).

- Electric Vehicles - using electric motors with battery energy storage.

Flex-fuel vehicles, which run on a wide mixture range of gasoline and ethanol, are also included in the Quality Metrics analysis. The attributes of flex-fuel vehicles are the same as conventional, except for the fueling options. As is discussed below the benefits analysis for this technology is fuel-supply based.

Consistent with current OTT program scope, it was assumed that the technologies are widely applicable throughout the vehicle classes. Fuel cell vehicles are not considered in small cars or pickups and large vans. The gasoline fuel cell is replaced by the hydrogen fuel cell in the vehicle classes before 2030. LPG and methanol also are not considered in this analysis because: 1) OTT conducts minimal R\&D efforts with these fuels; and 2) DOE Policy Office analysis indicates that these fuels would be imported in large amounts if they were used on a large scale in the transportation sector (Ref. 4). As a result, replacing imported petroleum with imported LPG or methanol would not help the U.S. trade balance or energy security.

Note that the values presented are intended to project the relative effects of the OTT programs only. Other market effects outside of OTT's purview (conventional diesel-powered light vehicles, methanol fuel, other fuels, etc.) are not considered. Therefore, the total market penetration or benefits values should not be used in external comparisons; only the relative change numbers are valid. Of principal concern to the analysis are the alternative vehicle fuel economy, cost, relative range and maintenance cost in comparison to conventional vehicles. Vehicle storage (i.e. trunk) capacity, and acceleration also are of interest. Fuel economy ratio assumptions are indicated in Exhibit 3-1.

In the QM 2003 analysis, two fuel cell fueling options are considered; gasoline and hydrogen. The baseline large car gasoline-fueled fuel cell vehicle exhibits an initial fuel economy ratio of 
1.9 increasing to 2.5 at the end of the analysis period. For the hydrogen option, these corresponding values are 2.5 and 3.0 reflecting a higher initial fuel economy due to the absence of the gasoline-reforming step, but introduced later. Stratified-charge Spark Ignition engine technology, considered in prior years was dropped from consideration in QM 2003. This technology is not currently being supported within the OTT program.

Exhibit 3-1: Fuel Economy Ratio

\begin{tabular}{||l|l|c|c|c|c|c|}
\hline \multirow{2}{*}{ TECHNOLOGY } & STATUS & SMALL CAR & LARGE CAR & MINIVAN & $\begin{array}{c}\text { SPORT } \\
\text { UTILITY } \\
\text { VEHICLE }\end{array}$ & $\begin{array}{c}\text { PICKUP } \\
\text { TRUCK \& } \\
\text { LARGE VAN }\end{array}$ \\
\hline \multirow{2}{*}{ ADVANCED DIESEL } & Initial & 1.40 & 1.40 & 1.40 & 1.40 & 1.40 \\
\cline { 2 - 7 } & Final & 1.40 & 1.40 & 1.40 & 1.40 & 1.40 \\
\hline \multirow{2}{*}{ FUEL CELL-Hydrogen } & Initial & 2.50 & 2.20 & 2.00 & 2.00 & 2.00 \\
\cline { 2 - 7 } & Final & 3.00 & 3.00 & 3.00 & 3.00 & 3.00 \\
\hline \multirow{3}{*}{ FUEL CELL-Gasoline } & Initial & $\mathrm{n} / \mathrm{a}$ & 1.90 & 1.75 & 1.75 & $\mathrm{n} / \mathrm{a}$ \\
\cline { 2 - 7 } & Final & $\mathrm{n} / \mathrm{a}$ & 2.50 & 2.50 & 2.50 & $\mathrm{n} . \mathrm{a}$ \\
\hline \multirow{2}{*}{ ENG DEDICATED } & Initial & 1.00 & 1.00 & 1.00 & 1.00 & 1.00 \\
\cline { 2 - 7 } & Final & 1.00 & 1.00 & 1.00 & 1.00 & 1.00 \\
\hline \multirow{2}{*}{ HYBRID-A } & Initial & 4.00 & 4.00 & 4.00 & 4.00 & 4.00 \\
\cline { 2 - 7 } & Final & 4.00 & 4.00 & 4.00 & 4.00 & 4.00 \\
\hline & Initial & 1.25 & 1.50 & 1.50 & 1.25 & 1.60 \\
\cline { 2 - 7 } & Final & 2.00 & 2.00 & 2.00 & 2.00 & 2.00 \\
\hline \multirow{2}{*}{ HYBRID-B } & Initial & 2.30 & 2.00 & 2.00 & 1.90 & 2.00 \\
\cline { 2 - 7 } & Final & 3.00 & 3.00 & 3.00 & 3.00 & 3.00 \\
\hline
\end{tabular}

As indicated in Exhibit 3-1, the electric, CIDI, hybrid-electric, and fuel cell vehicles have significantly better fuel economies than conventional vehicles. All technology fuel economy ratios are applicable to the point of use, including electric vehicles, which reflect comparisons at the plug and the fuel tanks.

The capital or purchase cost ratios are shown in Exhibit 3-2. The cost comparison indicates that the non-conventional vehicle technologies are consistently more expensive than conventional with premium for the Advanced Diesel vehicles generally having the lowest cost increase. When comparing ranges, electric and natural gas-fueled vehicles are found to have significant range penalties. Diesel vehicles however, have a range benefit, due in part to the higher volumetric energy content of diesel fuel compared with gasoline. Maintenance costs differ substantially with the advanced technology vehicles compared to conventional vehicles with ratios ranging from 0.6 to 1.10 .

Exhibit 3-3 shows the comparison of relative ranges. Exhibit 3-4 shows the comparison of relative maintenance cost. 
Exhibit 3-2: Capital Cost Ratio

\begin{tabular}{|c|c|c|c|c|c|c|}
\hline TECHNOLOGY & STATUS & SMALL CAR & LARGE CAR & MINIVAN & $\begin{array}{c}\text { SPORT } \\
\text { UTILITY } \\
\text { VEHICLE }\end{array}$ & $\begin{array}{c}\text { PICKUP } \\
\text { TRUCK \& } \\
\text { LARGE VAN }\end{array}$ \\
\hline \multirow[t]{2}{*}{ ADVANCED DIESEL } & INITIAL & 1.07 & 1.07 & 1.08 & 1.08 & 1.10 \\
\hline & FINAL & 1.07 & 1.05 & 1.07 & 1.07 & 1.07 \\
\hline \multirow[t]{2}{*}{ FUEL CELL-HYDROGEN } & INITIAL & 1.35 & 1.40 & 1.35 & 1.40 & 1.35 \\
\hline & FINAL & 1.15 & 1.15 & 1.15 & 1.15 & 1.15 \\
\hline \multirow[t]{2}{*}{ FUEL CELL-GASOLINE } & INITIAL & $\mathrm{n} / \mathrm{a}$ & 1.40 & 1.35 & 1.40 & $\mathrm{n} / \mathrm{a}$ \\
\hline & FINAL & $\mathrm{n} / \mathrm{a}$ & 1.20 & 1.28 & 1.26 & $\mathrm{n} / \mathrm{a}$ \\
\hline \multirow[t]{2}{*}{ CNG DEDICATED } & INITIAL & 1.08 & 1.10 & 1.05 & 1.05 & 1.10 \\
\hline & FINAL & 1.08 & 1.04 & 1.05 & 1.05 & 1.10 \\
\hline \multirow[t]{2}{*}{ ELECTRIC } & INITIAL & 2.70 & 1.90 & 1.90 & 1.50 & 2.70 \\
\hline & FINAL & 1.50 & 1.50 & 1.50 & 1.40 & 1.50 \\
\hline \multirow[t]{2}{*}{ HYBRID-A } & INITIAL & 1.33 & 1.25 & 1.25 & 1.25 & 1.20 \\
\hline & FINAL & 1.05 & 1.05 & 1.05 & 1.05 & 1.05 \\
\hline \multirow[t]{2}{*}{ HYBRID-B } & INITIAL & 1.25 & 1.30 & 1.25 & 1.30 & 1.25 \\
\hline & FINAL & 1.10 & 1.10 & 1.10 & 1.10 & 1.10 \\
\hline
\end{tabular}

Exhibit 3-3: Relative Range Ratio

\begin{tabular}{|c|c|c|c|c|c|c|}
\hline TECHNOLOGY & STATUS & SMALL CAR & LARGE CAR & MINIVAN & $\begin{array}{c}\text { SPORT } \\
\text { UTILITY } \\
\text { VEHICLE }\end{array}$ & $\begin{array}{c}\text { PICKUP } \\
\text { TRUCK \& } \\
\text { LARGE VAN }\end{array}$ \\
\hline \multirow[t]{2}{*}{ ADVANCED DIESEL } & INITIAL & 1.20 & 1.20 & 1.20 & 1.20 & 1.20 \\
\hline & FINAL & 1.20 & 1.20 & 1.20 & 1.20 & 1.20 \\
\hline \multirow[t]{2}{*}{ FUEL CELL-HYDROGEN } & INITIAL & 0.75 & 0.90 & 0.90 & 0.90 & 0.90 \\
\hline & FINAL & 0.75 & 0.90 & 0.90 & 0.90 & 0.00 \\
\hline \multirow[t]{2}{*}{ FUEL CELL-GASOLINE } & INITIAL & $\mathrm{n} / \mathrm{a}$ & 1.00 & 1.00 & 1.00 & $\mathrm{n} / \mathrm{a}$ \\
\hline & FINAL & $\mathrm{n} / \mathrm{a}$ & 1.00 & 1.00 & 1.00 & $\mathrm{n} / \mathrm{a}$ \\
\hline \multirow[t]{2}{*}{ CNG DEDICATED } & INITIAL & 0.66 & 0.66 & 0.75 & 0.75 & 0.75 \\
\hline & FINAL & 0.66 & 0.75 & 0.75 & 0.75 & 0.75 \\
\hline \multirow[t]{2}{*}{ ELECTRIC } & INITIAL & 0.33 & 0.36 & 0.38 & 0.60 & 0.33 \\
\hline & FINAL & 0.40 & 0.75 & 0.60 & 0.60 & 0.40 \\
\hline \multirow[t]{2}{*}{ HYBRID-A } & INITIAL & 1.00 & 1.20 & 1.00 & 1.00 & 1.00 \\
\hline & FINAL & 1.00 & 1.20 & 1.00 & 1.00 & 1.00 \\
\hline \multirow[t]{2}{*}{ HYBRID-B } & INITIAL & 1.00 & 1.00 & 1.00 & 1.00 & 0.80 \\
\hline & FINAL & 1.00 & 1.00 & 1.00 & 1.00 & 0.80 \\
\hline
\end{tabular}


Exhibit 3-4: Relative Maintenance

\begin{tabular}{|c|c|c|c|c|c|c|}
\hline TECHNOLOGY & STATUS & SMALL CAR & LARGE CAR & MINIVAN & $\begin{array}{c}\text { SPORT } \\
\text { UTILITY } \\
\text { VEHICLE }\end{array}$ & $\begin{array}{c}\text { PICKUP } \\
\text { TRUCK \& } \\
\text { LARGE VAN }\end{array}$ \\
\hline \multirow[t]{2}{*}{ ADVANCED DIESEL } & INITIAL & 1.00 & 1.00 & 1.00 & 1.00 & 1.00 \\
\hline & FINAL & 1.00 & 1.00 & 1.00 & 1.00 & 1.00 \\
\hline \multirow[t]{2}{*}{ FUEL CELL-HYDROGEN } & INITIAL & 1.05 & 1.05 & 1.10 & 1.05 & 1.05 \\
\hline & FINAL & 0.90 & 0.90 & 0.90 & 0.90 & 0.00 \\
\hline \multirow[t]{2}{*}{ FUEL CELL-GASOLINE } & INITIAL & $\mathrm{n} / \mathrm{a}$ & 1.05 & 1.05 & 1.05 & $\mathrm{n} / \mathrm{a}$ \\
\hline & FINAL & $\mathrm{n} / \mathrm{a}$ & 0.91 & 1.00 & 1.00 & $\mathrm{n} / \mathrm{a}$ \\
\hline \multirow[t]{2}{*}{ CNG DEDICATED } & INITIAL & 0.90 & 0.90 & 0.90 & 0.90 & 0.90 \\
\hline & FINAL & 0.90 & 0.90 & 0.90 & 0.90 & 0.90 \\
\hline \multirow[t]{2}{*}{ ELECTRIC } & INITIAL & 0.60 & 0.60 & 0.60 & 0.60 & 0.60 \\
\hline & FINAL & 0.60 & 0.60 & 0.60 & 0.60 & 0.60 \\
\hline \multirow[t]{2}{*}{ HYBRID-A } & INITIAL & 1.05 & 1.05 & 1.05 & 1.05 & 1.05 \\
\hline & FINAL & 1.00 & 1.00 & 1.00 & 1.00 & 1.00 \\
\hline \multirow[t]{2}{*}{ HYBRID-B } & INITIAL & 1.05 & 1.05 & 1.10 & 1.05 & 1.05 \\
\hline & FINAL & 0.90 & 0.90 & 0.90 & 0.90 & 0.90 \\
\hline
\end{tabular}

The overall light vehicle sales penetration forecast is a weighted average of the sales penetration estimates provided by the VSCC Model by size class. Exhibit 3-5 details the sales and stocks of advanced light vehicle technologies in years 2010, 2020, and 2030. The analyses show that at aggressive market penetration rates, advanced technologies will comprise more than fifty percent (52.3\%) of light vehicle sales by 2010 . In fact, advanced vehicle technologies reach nearly seventy four percent (73.6\%) aggregate market penetration in 2020 although the stock of advanced vehicles in 2020 is forty nine percent (49.0\%) as shown in Exhibit 3-5. By 2030, the alternative light vehicle sales are projected to constitute one hundred percent (100\%) of sales and nearly eighty percent (79.6\%) of stocks. (See Appendix A, Tables A-9 and A-13). Exhibit 3-6 is a chart developed from the same sales data.

Exhibit 3-5: Market Penetration of Alternative Light Vehicles-Sales and Stocks

\begin{tabular}{||l|c|c|c|c|c|c||}
\hline \multirow{2}{*}{\multicolumn{1}{|c|}{ TECHNOLOGY }} & \multicolumn{2}{|c|}{ YEAR 2010 } & \multicolumn{2}{c|}{ YEAR 2020 } & \multicolumn{2}{c|}{ YEAR 2030 } \\
\cline { 2 - 7 } & $\begin{array}{c}\text { SALES } \\
\%\end{array}$ & $\begin{array}{c}\text { STOCKS } \\
\%\end{array}$ & $\begin{array}{c}\text { SALES } \\
\%\end{array}$ & $\begin{array}{c}\text { STOCKS } \\
\%\end{array}$ & $\begin{array}{c}\text { SALES } \\
\%\end{array}$ & $\begin{array}{c}\text { STOCKS } \\
\%\end{array}$ \\
\hline Flex Alcohol & $13.2 \%$ & $5.8 \%$ & $6.8 \%$ & $8.6 \%$ & $9.5 \%$ & $7.4 \%$ \\
\hline Advanced Diesel & $21.1 \%$ & $4.3 \%$ & $18.6 \%$ & $15.5 \%$ & $20.3 \%$ & $18.6 \%$ \\
\hline Fuel Cell Hydrogen & $0.0 \%$ & $0.0 \%$ & $1.2 \%$ & $0.2 \%$ & $9.8 \%$ & $4.3 \%$ \\
\hline Fuel Cell Gasoline & $0.6 \%$ & $0.0 \%$ & $6.9 \%$ & $3.9 \%$ & $0.0 \%$ & $5.3 \%$ \\
\hline CNG Dedicated & $2.5 \%$ & $0.4 \%$ & $2.5 \%$ & $1.9 \%$ & $5.0 \%$ & $3.3 \%$ \\
\hline Electric & $0.5 \%$ & $0.0 \%$ & $2.5 \%$ & $1.2 \%$ & $5.3 \%$ & $3.4 \%$ \\
\hline Hybrid (A) & $12.6 \%$ & $2.9 \%$ & $21.3 \%$ & $13.5 \%$ & $26.0 \%$ & $21.5 \%$ \\
\hline Hybrid (B) & $1.9 \%$ & $0.2 \%$ & $13.7 \%$ & $4.1 \%$ & $24.1 \%$ & $15.8 \%$ \\
\hline TOTAL & $\mathbf{5 2 . 3 \%}$ & $\mathbf{1 3 . 7 \%}$ & $\mathbf{7 3 . 6 \%}$ & $\mathbf{4 9 . 0 \%}$ & $\mathbf{1 0 0 . 0} \%$ & $\mathbf{7 9 . 6 \%}$ \\
\hline
\end{tabular}


Exhibit 3-6: Market Penetration of Alternative Light Vehicles-Sales

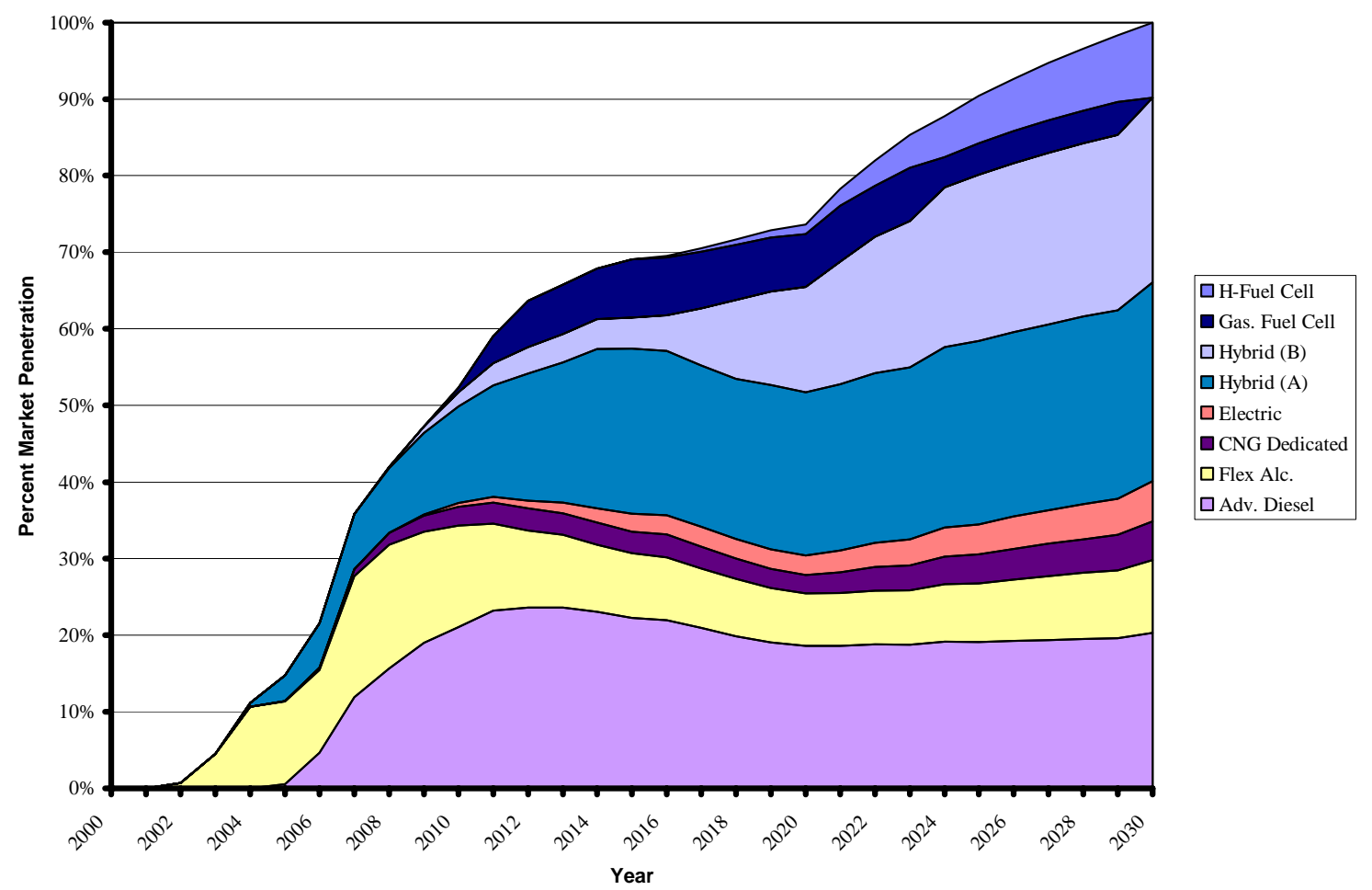

Exhibits 3-7 through 3-11 are charts of the market penetration of each vehicle class. In 2010, advanced diesel vehicles comprise thirty six percent (36\%), the largest fraction of alternative small cars (Exhibit 3-7). This share is reduced to twenty eight percent (28\%) by 2030 . Hybrid vehicles with twice baseline fuel economy (Type A) reach twenty four percent $(24 \%)$ of sales in 2010 and largely sustain this level through 2030 (23\%) while coming into full competition with Type B hybrids (those with ' 3 times' baseline fuel economy) which rise from nothing to twenty-five percent $(25 \%)$ in 2030.

\section{Exhibit 3-7: Market Penetration of Advanced Technologies in Small Cars}

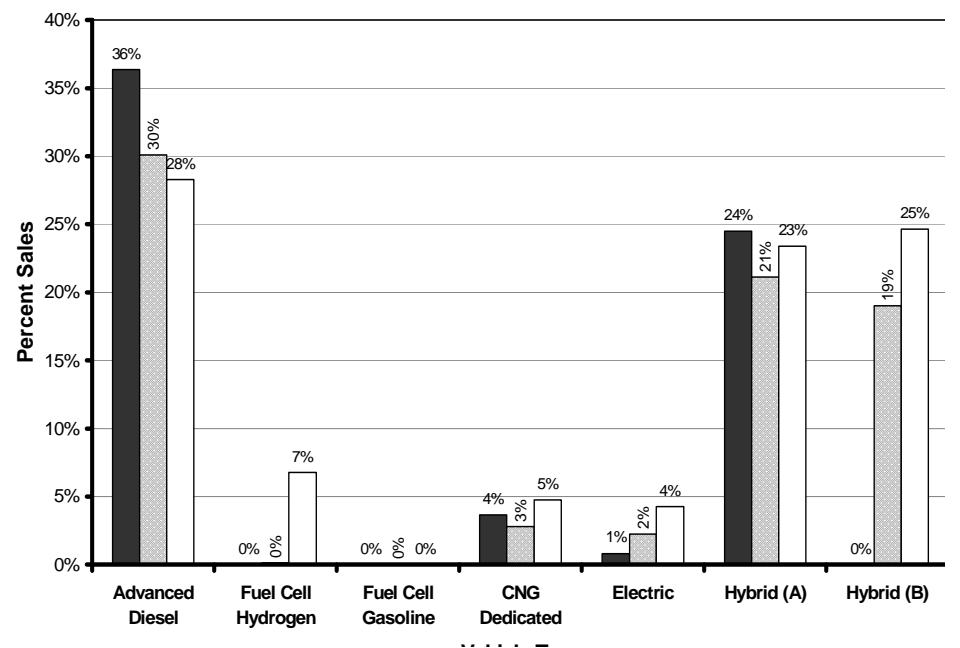


As shown in Exhibit 3-8, the scenario for alternative large car penetration indicates that Type A and Type B hybrids reach sales levels of eleven percent (11\%) and nearly eight percent (8\%) respectively in 2010 and maintain a commanding lead over the remaining twenty years. Advanced diesels penetrate to ten percent $(10 \%)$ initially and grow to fourteen $(14 \%)$ by 2030. Both fuel cell configurations also show an important market penetration.

From Exhibit 3-9 it can be seen that advanced diesel technology dominates the minivan and small truck market sector, with nineteen percent $(19 \%)$ of new car sales in 2010, and growing to twenty-seven percent $(27 \%)$ by 2030 . The hybrid technologies also show good market penetration, with hybrid $\mathrm{A}$, approaching fifteen percent (15\%) of new car sales by 2020, and passing twenty percent $(20 \%)$ by 2030 . As fuel cell technology becomes available, it also competes well.

Exhibit 3-10 shows that sport utility buyers are projected to be highly receptive to both hybrids $A$ and $\mathrm{B}$, and the advanced diesel technologies, which perform well from 2010 through 2030. Both hybrid
Exhibit 3-8: Market Penetration of Advanced Technologies In Large Cars

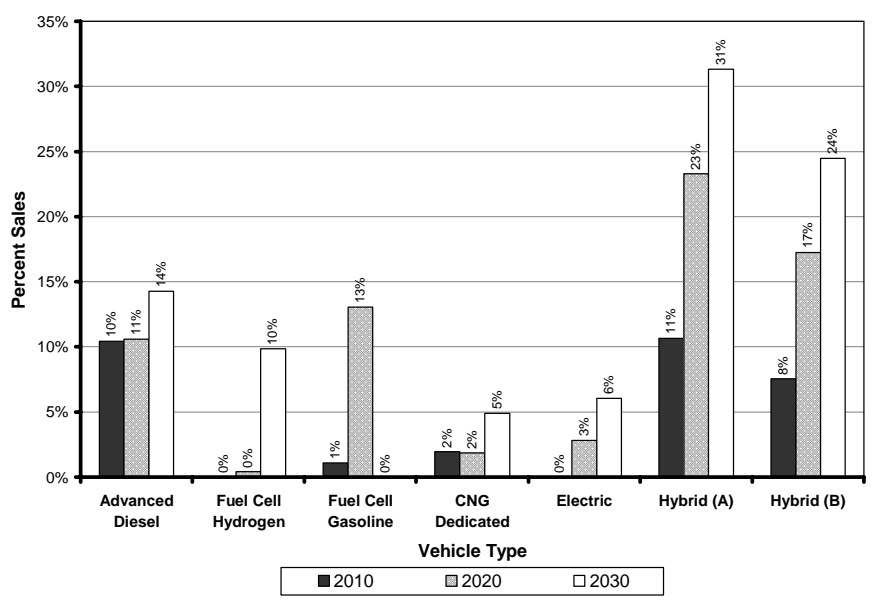

Exhibit 3-9: Market Penetration of Advanced Technologies in Minivans

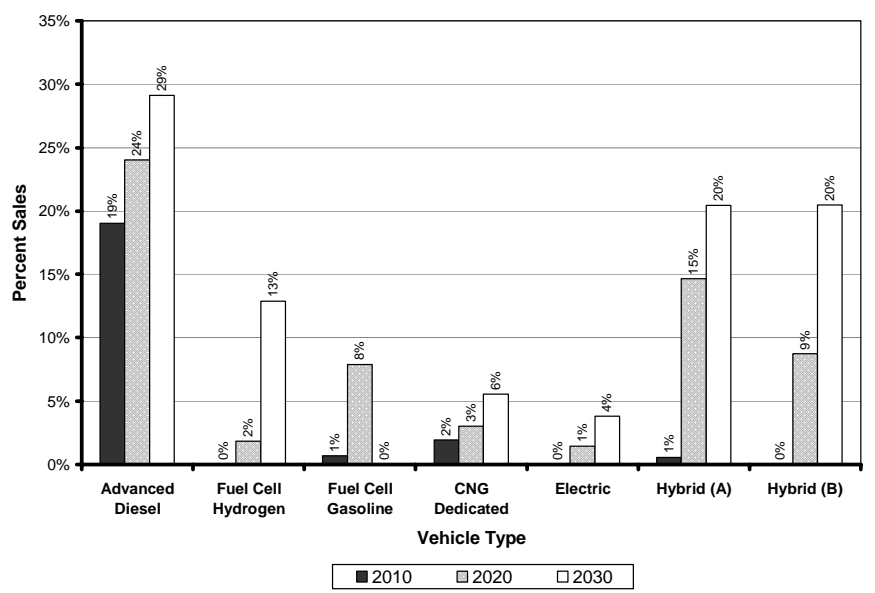

Exhibit 3-10: Market Penetration of Advanced Technologies in Sport Utility Vehicles

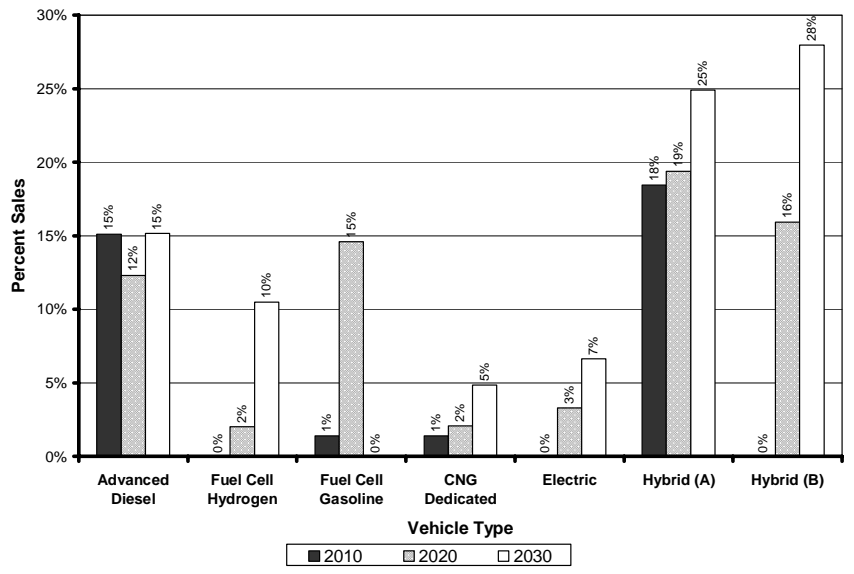


configurations account for fifty-three percent (53\%) by 2030. Fuel cell vehicles also do reasonably well, but the gasoline fuel cell SUV fades near the end of the analysis period, being replaced by the better-performing hydrogen fuel cell vehicle.

Hybrids and advanced diesels tend to dominate the pickup and large van market. In 2010 with advanced diesels accounting for nineteen percent $(19 \%)$ of new car sales fading slightly from importance after 2010 due to the rapidly growing popularity of the hybrids as indicated in Exhibit 3-11. Fuel cells also perform well, with hydrogen fuel cells

Exhibit 3-11: Market Penetration of Advanced Technologies in Pickups \& Large Vans

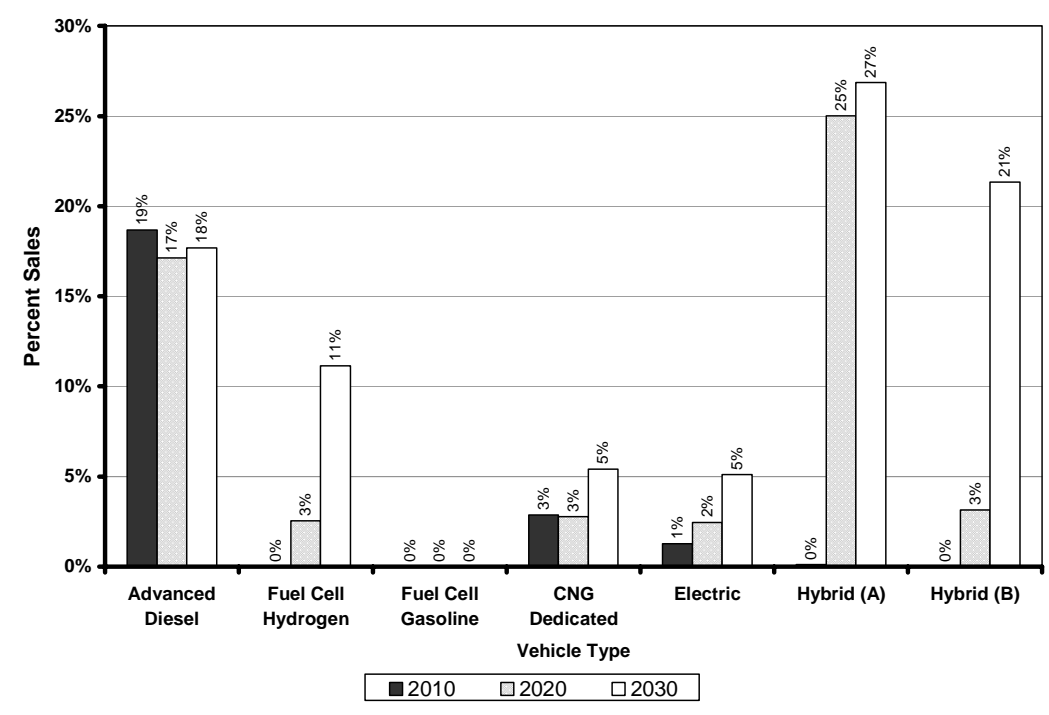

accounting for eleven percent $(11 \%)$ of sales in 2030 . Gasoline fuel cells are not competing in this vehicle size class by 2030 .

Exhibit 3-12 presents the data used to generate Exhibits 3-7 through 3-11 in tabular format. These results were extracted from Appendix Table A-9, which contains a more detailed presentation of the market penetration results, by size class for each year of the analysis period. 
Exhibit 3-12: Advanced Technology Market Penetration Results by Vehicle Size ClassTabular format

\begin{tabular}{|c|c|c|c|c|c|c|}
\hline Technology & 2010 & 2020 & 2030 & 2010 & 2020 & 2030 \\
\hline & \multicolumn{3}{|c|}{ Small Car } & \multicolumn{3}{|c|}{ Large Car } \\
\hline Conventional & $25 \%$ & $19 \%$ & $0 \%$ & $54 \%$ & $25 \%$ & $0 \%$ \\
\hline Flex Alcohol & $9 \%$ & $6 \%$ & $8 \%$ & $14 \%$ & $6 \%$ & $9 \%$ \\
\hline Advanced Diesel & $36 \%$ & $30 \%$ & $28 \%$ & $10 \%$ & $11 \%$ & $14 \%$ \\
\hline Dedicated Alcohol & $0 \%$ & $0 \%$ & $0 \%$ & $0 \%$ & $0 \%$ & $0 \%$ \\
\hline Fuel Cell Hydrogen & $0 \%$ & $0 \%$ & $7 \%$ & $0 \%$ & $0 \%$ & $10 \%$ \\
\hline Fuel Cell Gasoline & $0 \%$ & $0 \%$ & $0 \%$ & $1 \%$ & $13 \%$ & $0 \%$ \\
\hline CNG Dedicated & $4 \%$ & $3 \%$ & $5 \%$ & $2 \%$ & $2 \%$ & $5 \%$ \\
\hline CNG Bi-fuel & $0 \%$ & $0 \%$ & $0 \%$ & $0 \%$ & $0 \%$ & $0 \%$ \\
\hline Electric & $1 \%$ & $2 \%$ & $4 \%$ & $0 \%$ & $3 \%$ & $6 \%$ \\
\hline Hybrid (A) & $24 \%$ & $21 \%$ & $23 \%$ & $11 \%$ & $23 \%$ & $31 \%$ \\
\hline Hybrid (B) & $0 \%$ & $19 \%$ & $25 \%$ & $8 \%$ & $17 \%$ & $24 \%$ \\
\hline \multirow[t]{2}{*}{ TOTAL } & $100 \%$ & $100 \%$ & $100 \%$ & $100 \%$ & $100 \%$ & $100 \%$ \\
\hline & \multicolumn{3}{|c|}{ Minivan } & \multicolumn{3}{|c|}{ Sport Utility Vehicle } \\
\hline Conventional & $66 \%$ & $33 \%$ & $0 \%$ & $50 \%$ & $24 \%$ & $0 \%$ \\
\hline Flex Alcohol & $12 \%$ & $5 \%$ & $8 \%$ & $14 \%$ & $6 \%$ & $10 \%$ \\
\hline Advanced Diesel & $19 \%$ & $24 \%$ & $29 \%$ & $15 \%$ & $12 \%$ & $15 \%$ \\
\hline Dedicated Alcohol & $0 \%$ & $0 \%$ & $0 \%$ & $0 \%$ & $0 \%$ & $0 \%$ \\
\hline Fuel Cell Hydrogen & $0 \%$ & $2 \%$ & $13 \%$ & $0 \%$ & $2 \%$ & $10 \%$ \\
\hline Fuel Cell Gasoline & $1 \%$ & $8 \%$ & $0 \%$ & $1 \%$ & $15 \%$ & $0 \%$ \\
\hline CNG Dedicated & $2 \%$ & $3 \%$ & $6 \%$ & $1 \%$ & $2 \%$ & $5 \%$ \\
\hline CNG Bi-fuel & $0 \%$ & $0 \%$ & $0 \%$ & $0 \%$ & $0 \%$ & $0 \%$ \\
\hline Electric & $0 \%$ & $1 \%$ & $4 \%$ & $0 \%$ & $3 \%$ & $7 \%$ \\
\hline Hybrid (A) & $1 \%$ & $15 \%$ & $20 \%$ & $18 \%$ & $19 \%$ & $25 \%$ \\
\hline Hybrid (B) & $0 \%$ & $9 \%$ & $20 \%$ & $0 \%$ & $16 \%$ & $28 \%$ \\
\hline \multirow[t]{2}{*}{ TOTAL } & $100 \%$ & $100 \%$ & $100 \%$ & $100 \%$ & $100 \%$ & $100 \%$ \\
\hline & \multicolumn{3}{|c|}{ Pickup \& Large Van } & & & \\
\hline Conventional & $59 \%$ & $37 \%$ & $0 \%$ & & & \\
\hline Flex Alcohol & $18 \%$ & $10 \%$ & $12 \%$ & & & \\
\hline Advanced Diesel & $19 \%$ & $17 \%$ & $18 \%$ & & & \\
\hline Dedicated Alcohol & $0 \%$ & $0 \%$ & $0 \%$ & & & \\
\hline Fuel Cell Hydrogen & $0 \%$ & $3 \%$ & $11 \%$ & & & \\
\hline Fuel Cell Gasoline & $0 \%$ & $0 \%$ & $0 \%$ & & & \\
\hline CNG Dedicated & $3 \%$ & $3 \%$ & $5 \%$ & & & \\
\hline CNG Bi-fuel & $0 \%$ & $0 \%$ & $0 \%$ & & & \\
\hline Electric & $1 \%$ & $2 \%$ & $5 \%$ & & & \\
\hline Hybrid (A) & $0 \%$ & $25 \%$ & $27 \%$ & & & \\
\hline Hybrid (B) & $0 \%$ & $3 \%$ & $21 \%$ & & & \\
\hline TOTAL & $100 \%$ & $100 \%$ & $100 \%$ & & & \\
\hline
\end{tabular}


Exhibit 3-13 shows the sales penetration for the combined five vehicle classes for the year 2010 .

Exhibits 3-14 and 3-15 show the same for the years 2020 and 2030. Cumulative vehicle "stocks" for each technology also are indicated. Note that sales are a percent of overall sales for that year, whereas stocks are a percent of the overall vehicle fleet in that year. In a growth market, sales shares tend to be greater than stock shares. This is reflected in the exhibits where the sales/stock ratio is significant greater than 1.0, i.e., for 2010 (Exhibits 3-13 \& 14) but much closer to parity in 2030 (Exhibit 3-15).
Exhibit 3-13: Alternative Light Vehicle Sales and Stocks, 2010

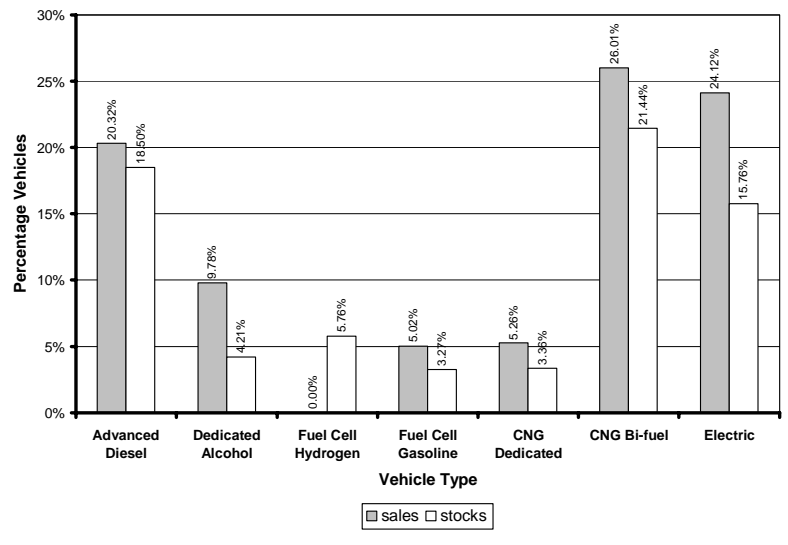

Exhibit 3-14: Alternative Light Vehicle Sales and Stocks, 2020

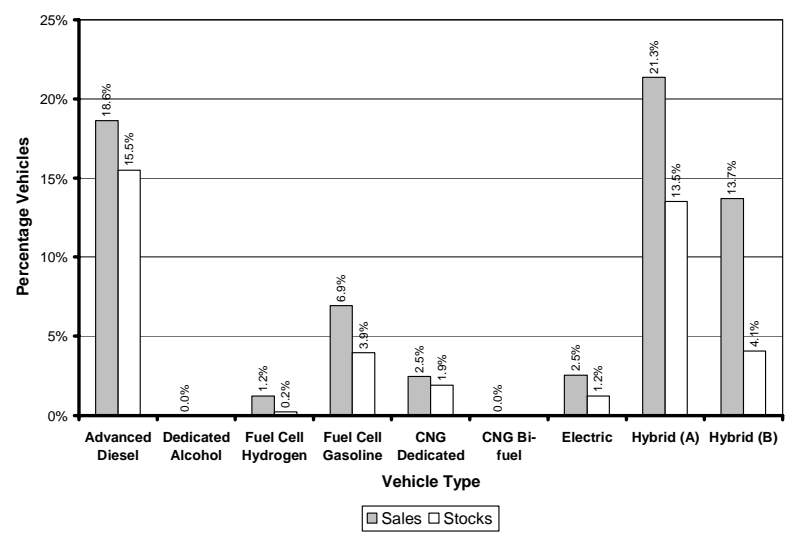

Exhibit 3-15: Alternative Light Vehicle Sales and Stocks, 2030

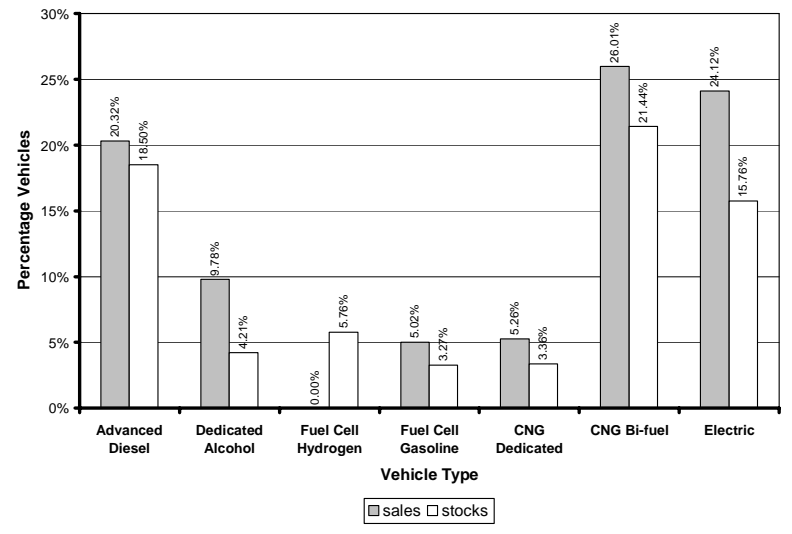




\subsection{Heavy Vehicles}

The Heavy Vehicle Market Penetration (HVMP) model was developed to estimate the potential market impacts of new technologies on the medium and heavy truck market as follows.

- Medium - Classes 3 through 6 and,

- Heavy - Classes 7 and 8 are further subdivided by end-use characteristics:

- Type 1 - multi-stop, step van, beverage, utility, winch, crane, wrecker, logging, pipe, garbage collection, dump, and concrete delivery;

- Type 2 - platform, livestock, auto transport, oil-field, grain, and tank;

- Type 3 - refrigerated van, drop frame van, open top van, and basic enclosed van.

The HVMP model was configured using the 1997 Vehicle Inventory and Use Survey (VIUS-Ref. 5). Data were examined for all vehicles in use and vehicles two years old or less. The HVMP model utilizes the data constructed from the two years old or less database. The heavy vehicle market was analyzed to develop market segments with similar operation and use patterns. Refueling and travel characteristics were specifically addressed by vehicle body type and major use classification for the two market segments.

Heavy vehicle characteristics are summarized in Exhibit 3-16. In the medium truck market segment (Classes 3 through 6), all vehicle types, with the exception of auto transport, on average travel about 20,000 miles per year. Heavy trucks, depending on type, travel an average of 40,000 miles to 92,000 miles per year. One of the more interesting findings was the significant difference in fuel economy among the vehicle types with Type 3 heavy vehicles exhibiting an average fuel economy nearly twice as high as Type 1 heavy vehicles ( 8.90 vs 4.55 MPG).

In the HVMP model, the truck classes are further segmented according to refueling location (i.e. central or multiple locations). As shown in Exhibit 3-16, all vehicle segments have central refueling occurring at least forty percent $(40.1 \%)$ of the time. As vehicles age, central refueling declines. This may be explained by the transition from larger fleet operations to small independent owner operators as centrally refueled vehicles age.

Exhibit 3-16: Heavy Vehicle Characteristics

\begin{tabular}{||l|c|c|c||}
\hline Vehicle Type & $\begin{array}{c}\text { Average } \\
\text { Annual } \\
\text { Miles (1) }\end{array}$ & $\begin{array}{c}\text { Fuel } \\
\text { Economy } \\
\text { (MPG) }\end{array}$ & $\begin{array}{c}\text { Percent } \\
\text { Centrally } \\
\text { Refueled } \\
\text { (1) }\end{array}$ \\
\hline Class 3-6 & 20,126 & 8.90 & $40.1 \%$ \\
\hline Class 7 \& 8 Type 1 & 40,043 & 4.55 & $59.8 \%$ \\
\hline Class 7 \& 8 Type 2 & 74,066 & 6.16 & $41.0 \%$ \\
\hline Class 7 \& 8 Type 3 & 92,434 & 8.90 & $42.0 \%$ \\
\hline
\end{tabular}

Note 1: Vehicles 2 years old or less

Overall market characteristics for vehicle stock, travel, and fuel use were also examined using the VIUS data (Exhibit 3-17). The data revealed that although medium trucks account for almost forty-one percent $(40.5 \%)$ of the combined medium and heavy vehicle stock, they account for just over sixteen percent $(16.3 \%)$ of vehicle miles traveled and fourteen percent (14.1\%) of fuel use. As expected, the data show that 
Class $7 \& 8$ vehicles account for a significant amount of travel and fuel use in the heavy vehicle market, nearly eighty-four percent $(83.8 \%)$ and eighty-six percent $(85.9 \%)$ respectively. It is also important to note that Type 3 vehicles show the greatest utilization, accounting for fifty percent $(50.4 \%)$ of all fuel use and fifty-eight percent $(58.1 \%)$ of all travel in the heavy vehicle market, while accounting for only thirty-five percent $(35.4 \%)$ of the stock.

In addition to the market characterization, historical market penetration data was obtained from VIUS surveys for energy conserving technologies including radial tires, aerodynamic devices, and fan clutches. This data was utilized in the calibration of the rate of efficiency technology adoption in the model. (Ref. 5).

The HVMP model estimates market penetration based on cost effectiveness of the new technology. Cost effectiveness is measured as the incremental cost of the new technology less the discounted expected energy savings of that technology over a specified time period.

Exhibit 3-18 shows the payback distribution assumed in the HVMP model. This payback distribution was generated using data taken from

Exhibit 3-17:

Heavy Vehicle Market Characteristics

\begin{tabular}{|c|c|c|c|}
\hline Vehicle Type & $\begin{array}{c}\text { Percent of } \\
\text { Total } \\
\text { Vehicle } \\
\text { Stock }\end{array}$ & $\begin{array}{c}\text { Percent of } \\
\text { Total VMT }\end{array}$ & $\begin{array}{c}\text { Percent of } \\
\text { Total Fuel } \\
\text { Use }\end{array}$ \\
\hline Class 3-6 & $40.5 \%$ & $16.3 \%$ & $14.1 \%$ \\
\hline Class 7 \& 8 & $59.5 \%$ & $83.8 \%$ & $85.9 \%$ \\
\hline Class 7 \& 8 Type 1 & $10.6 \%$ & $7.7 \%$ & $13.0 \%$ \\
\hline Class 7 \& 8 Type 2 & $13.4 \%$ & $17.9 \%$ & $22.5 \%$ \\
\hline Class 7 \& 8 Type 3 & $35.5 \%$ & $58.1 \%$ & $50.4 \%$ \\
\hline
\end{tabular}
a survey of 224 motor carriers conducted by the American Trucking Association. (Ref. 6) The survey found that, for example, $16.4 \%$ of the truck operators responding require a payback of one year on an investment.

Exhibit 3-18: Heavy Vehicle Payback Periods

The new technology cost and the expected efficiency improvements are exogenous inputs. Energy savings are calculated using the following data and assumptions:

- Annual vehicle miles traveled;

- Fuel efficiency (mpg) without new technology (Ref. 6);

- Fuel efficiency (mpg) with new technology;

- Projected fuel price - diesel, gasoline, ethanol and CNG (Ref. 7);

- Incremental cost of new technology over time (economies of scale);

- Discount rate; and

- Payback period. 
Eleven (11) travel distance categories for medium trucks and twenty-one (21) for heavy trucks are represented in the model. These categories were determined using travel distributions developed with the VIUS data by ORNL (Ref. 8). Graphs of the actual data are shown for each market segment, with central refueling and not-central refueling shown separately. All results have been reduced to eleven distance categories for presentation.

As Exhibits 3-19 and 3-20 show, the majority of medium trucks travel less than 40,000 miles per year, with about fifty percent $(52.4 \%)$ in the non-centrally refueled portion. Note that the percentages on the central and non-central refueling exhibits must be added to characterize $100 \%$ of the vehicle market.

Exhibit 3-19: Medium Vehicle Travel Distribution - Central Refueling

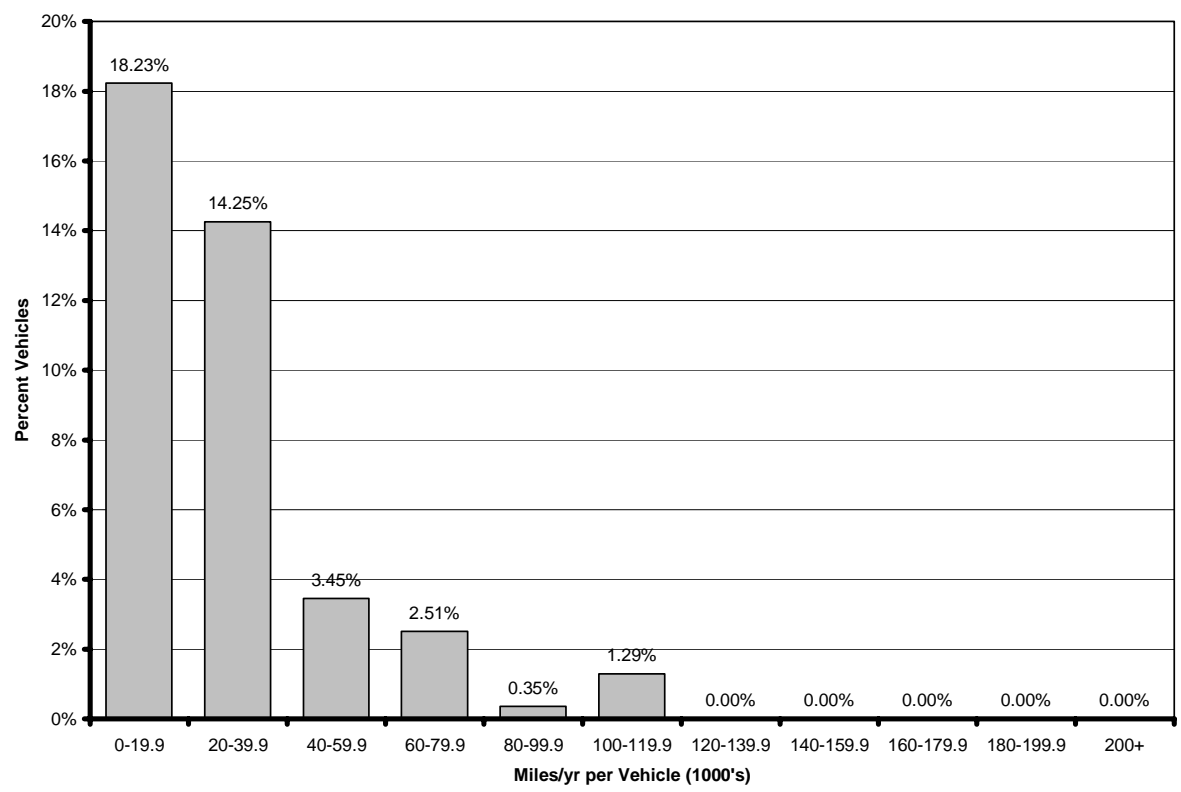

Exhibit 3-20: Medium Vehicle Travel Distribution - Non-Central Refueling

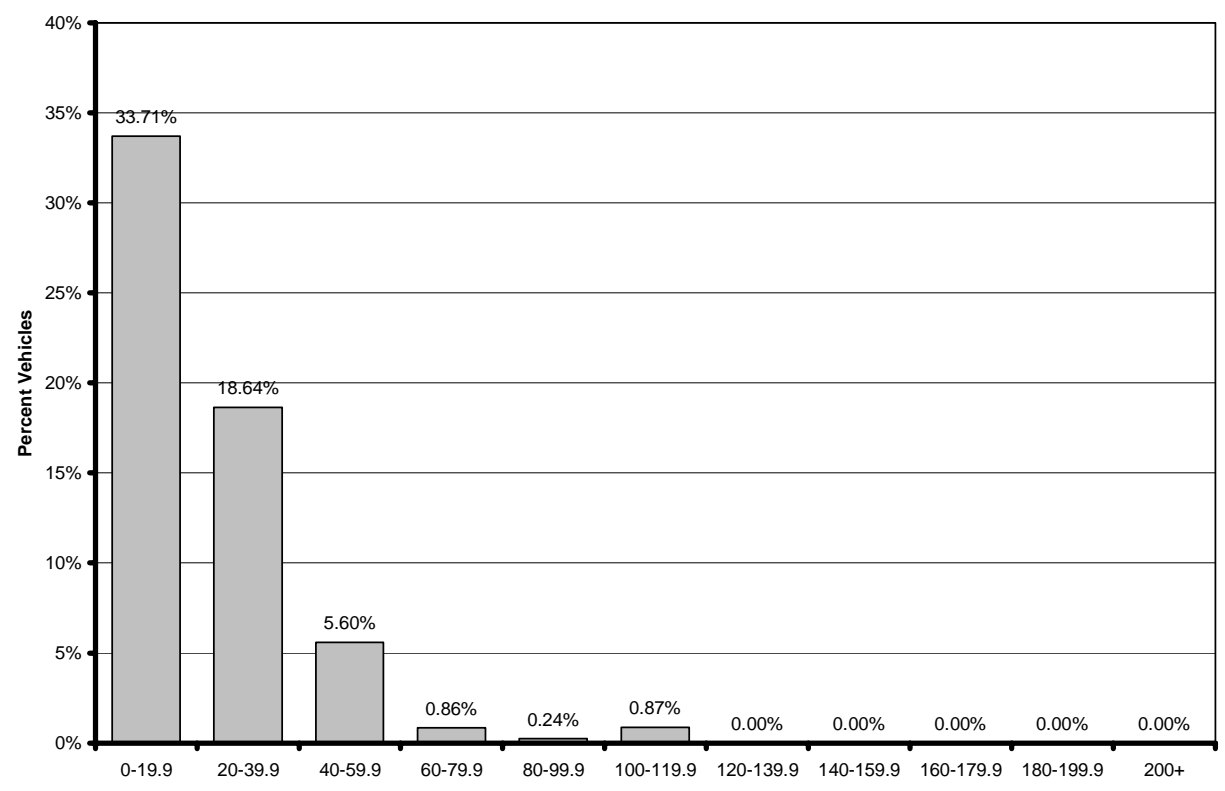


As shown in Exhibits 3-21 and 3-22, Type 1 vehicles exhibit travel patterns similar to that of medium vehicles. More than seventy-six percent $(76.4 \%)$ of such vehicles travel less than 60,000 miles per year. There are fewer non-centrally refueled vehicles in the type 1 market segment, but both segments have very similar travel characteristics.

\section{Exhibit 3-21: Type 1 Heavy Vehicle Travel Distribution - Central Refueling}

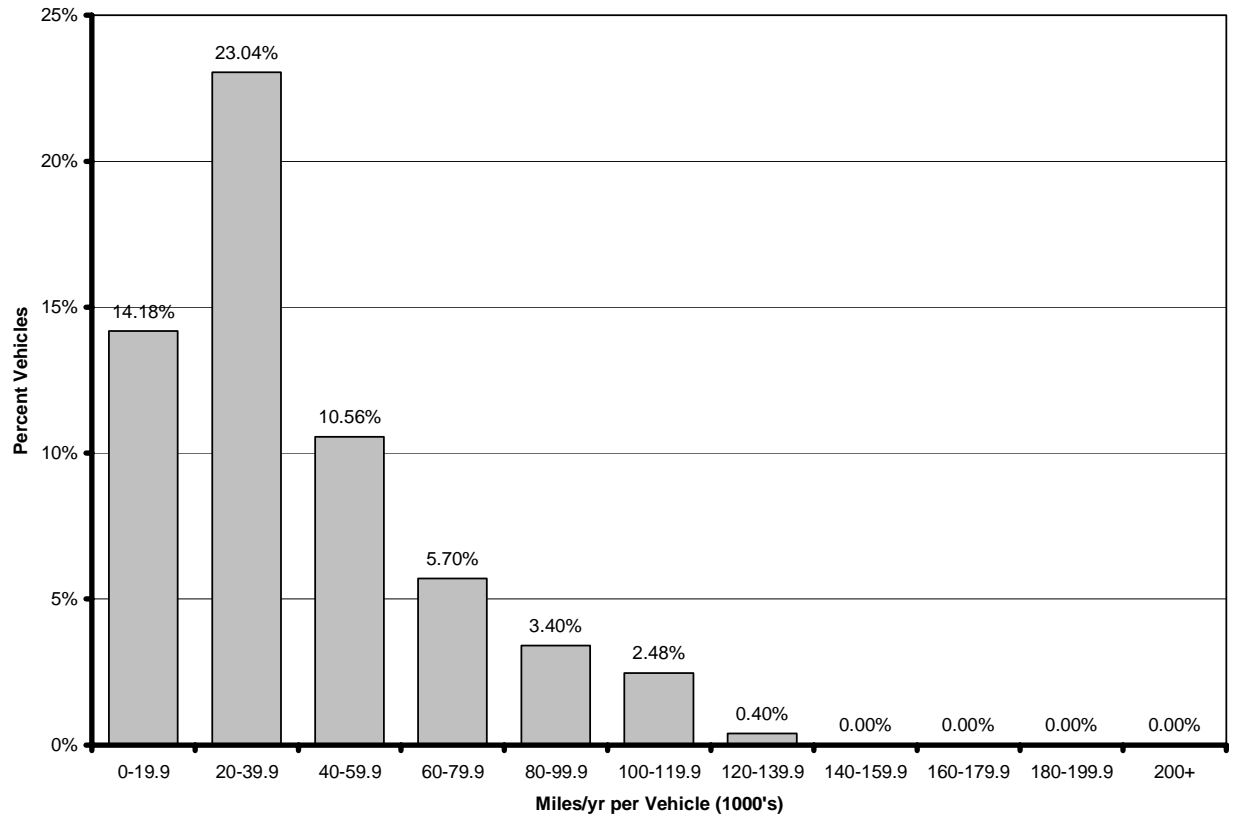

Exhibit 3-22: Type 1 Heavy Vehicle Travel Distribution - Non-Central Refueling

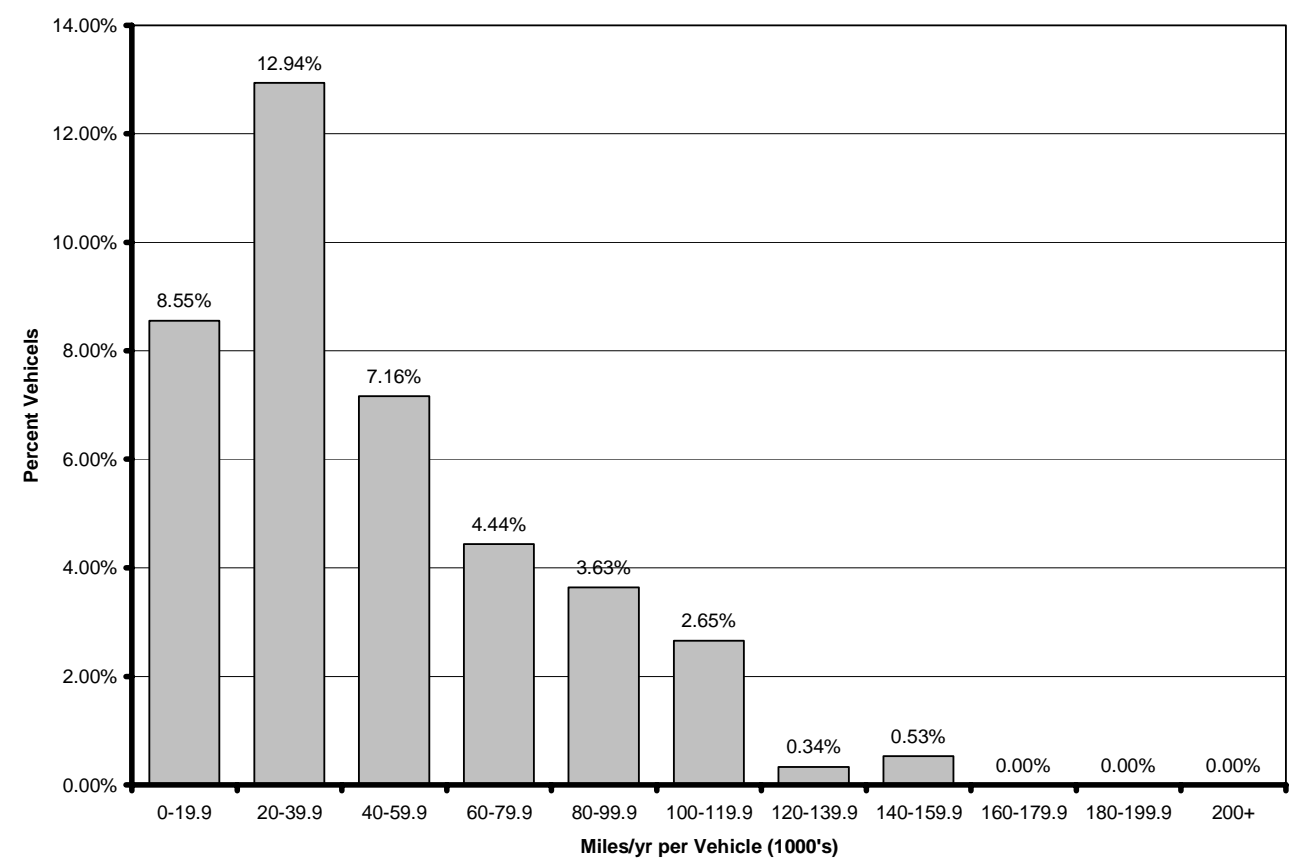

As shown in Exhibits 3-23 and 3-24, the type 2 vehicle travel distribution shows travel peaks at both the upper and middle ranges. Further analysis may reveal that some vehicle types in this 
segment may fit better in the type 1 or type 3 segment. As expected, travel in this market segment increases significantly for both the central and non-centrally fueled vehicles.

\section{Exhibit 3-23: Type 2 Heavy Vehicle Travel Distribution - Central Refueling}

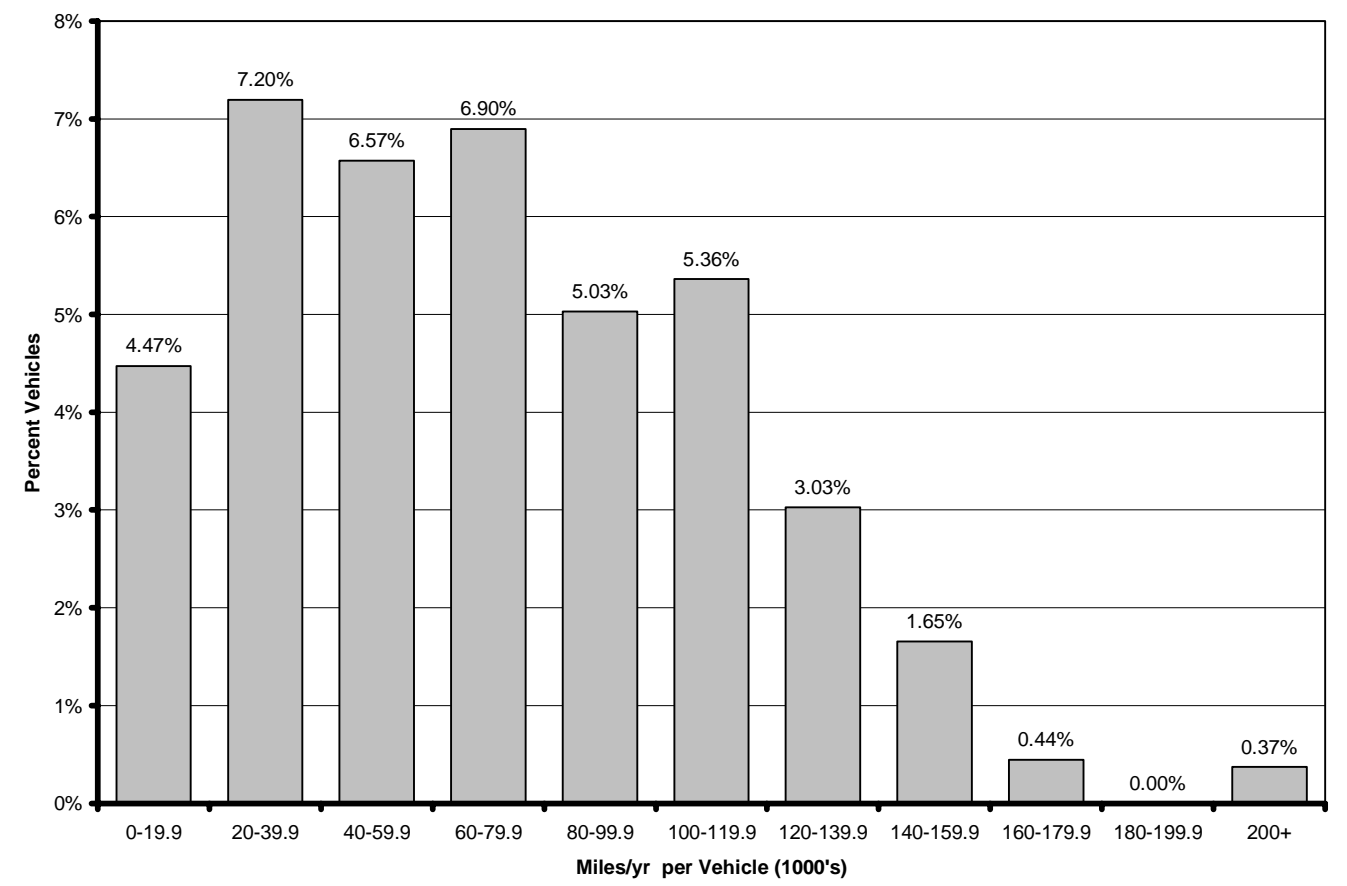

Exhibit 3-24: Type 2 Heavy Vehicle Travel Distribution - Non-Central Refueling

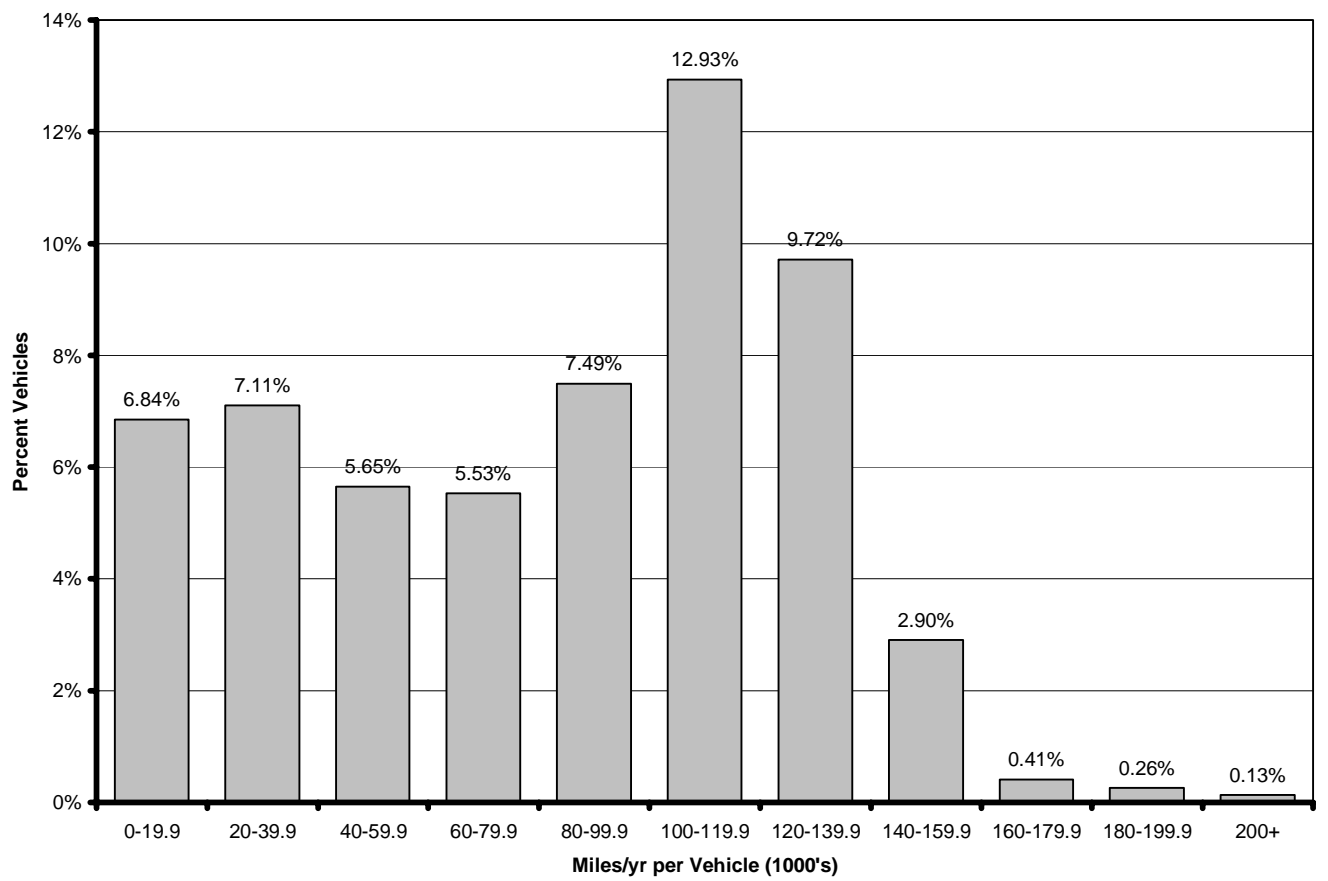


As shown in Exhibits 3-25 and 3-26, type 3 vehicles display the greatest of annual travel of all heavy vehicle classes. Centrally refueled vehicles travel less per year than non-centrally refueled vehicles. In the non-centrally refueled vehicle segment, the majority of travel occurs from 100,000 to 140,000 miles per year. In the central refueling segment, the majority of travel occurs below 140,000 miles per year.

\section{Exhibit 3-25: Type 3 Heavy Vehicle Travel Distribution - Central Refueling}

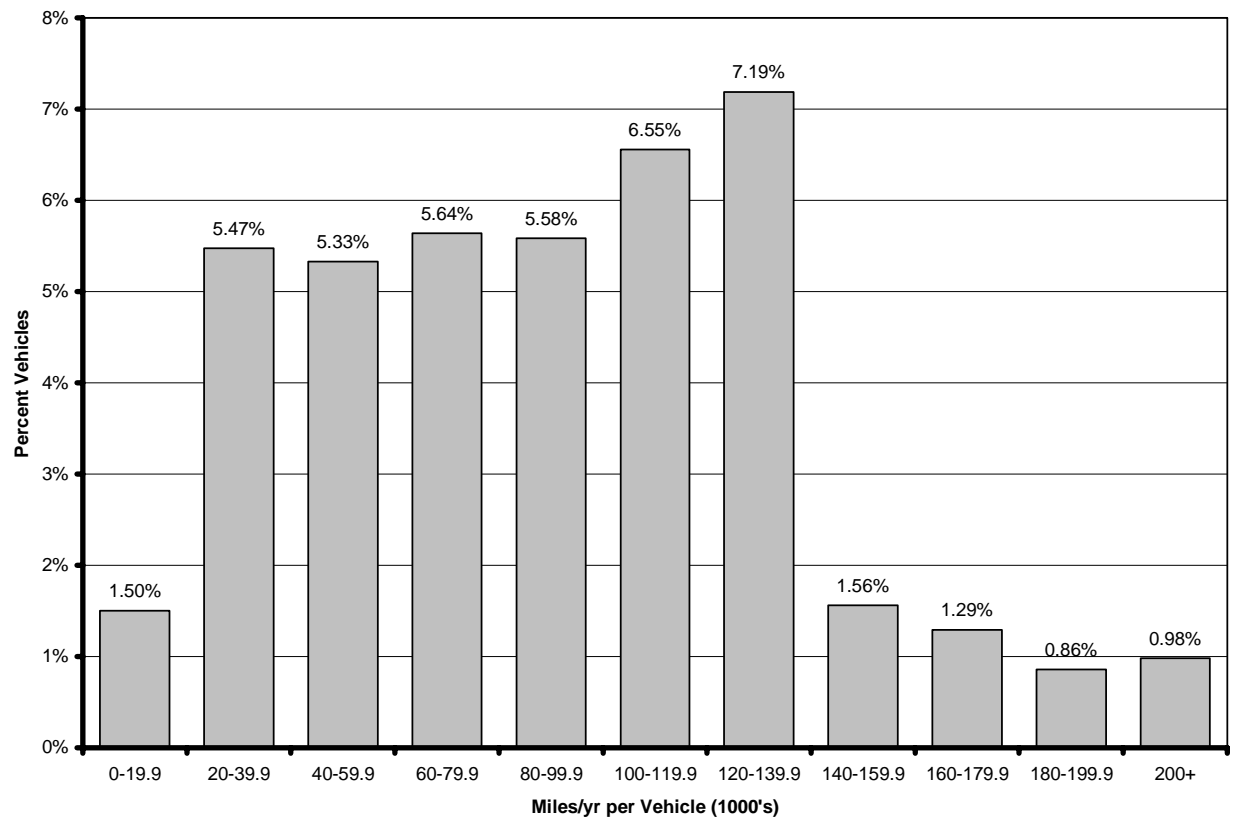

Exhibit 3-26: Type 3 Heavy Vehicle Travel Distribution - Non-Central Refueling

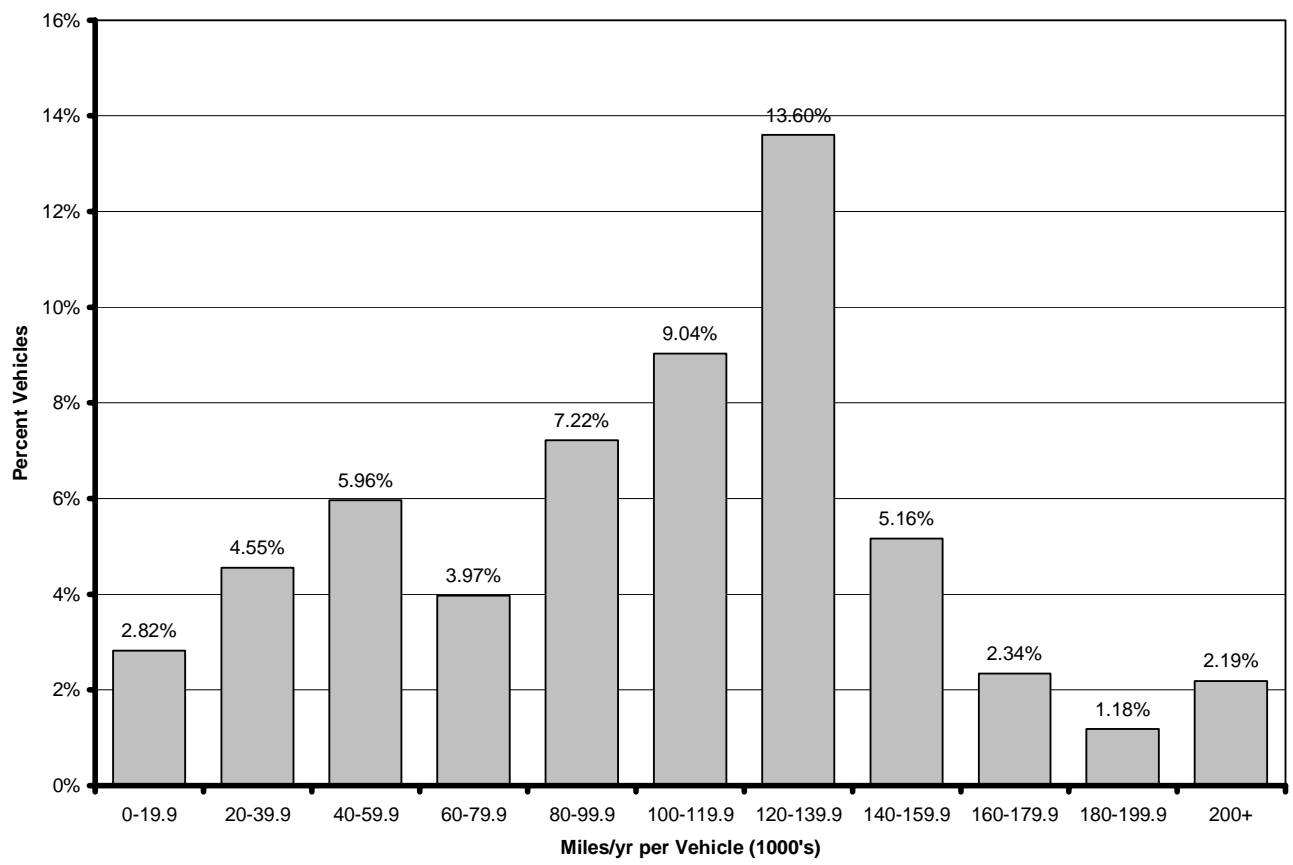


Technologies considered in QM 2003 include aerodynamic improvements, advanced diesel engine components, high efficiency turbochargers, improved lubrication systems, fuel cellpowered auxiliary systems and hybrid power systems in the medium class. The combinations of these technologies are shown in Exhibit 3-27.

Exhibit 3-27: Heavy Vehicle Technologies

\begin{tabular}{|l|l|}
\hline \multicolumn{1}{|c|}{ Class 3-6 } & \multicolumn{1}{|c|}{ Class 7\&8 } \\
\hline $\begin{array}{l}1 \text { Truck aerodynamic improvements } \\
\text { plus turbocharged diesel }\end{array}$ & $\begin{array}{l}\text { Truck aerodynamic improvements + } \\
\text { lubrication \& bearing improvements }\end{array}$ \\
\hline $\begin{array}{l}\text { 2 Improved engine with lower friction, } \\
\text { better injectors and efficient } \\
\text { combustion. }\end{array}$ & $\begin{array}{l}\text { Improved injectors \& more efficient } \\
\text { combustion }\end{array}$ \\
\hline 3 Hybrid Diesel & $\begin{array}{l}\text { Waste heat utilization + fuel cell auxiliary } \\
\text { power systems. }\end{array}$ \\
\hline
\end{tabular}

The incremental vehicle costs and fuel economy ratios of the advanced heavy vehicle technologies are indicated in Exhibit 3-28. The table illustrates the assumption that as a new technology is introduced into the market place and sales shares increase, costs are reduced.

\section{Exhibit 3-28: Heavy Vehicle Incremental Cost and Fuel Efficiency Ratios}

\begin{tabular}{|c|c|c|c|c|}
\hline Vehicle Class - Technology & Time & $\begin{array}{c}\text { Fuel } \\
\text { Efficiency } \\
\text { Ratio }\end{array}$ & Cost & Comments \\
\hline \multicolumn{5}{|l|}{ Class $3-6$} \\
\hline \multirow[t]{2}{*}{ Aerodynamice \& Turbocharded Diesel } & 2004 & 1.12 & 1,800 & \\
\hline & 2030 & 1.12 & 360 & Minimum cost by 2019 \\
\hline \multirow[t]{2}{*}{$\begin{array}{l}\text { Reduced friction, improved injectors \& } \\
\text { Improved Combustion Efficiency }\end{array}$} & 2008 & 1.08 & 2,000 & \\
\hline & 2030 & 1.08 & 400 & Minimum cost by 2023 \\
\hline \multirow[t]{2}{*}{ Hybrid Diesel } & 2010 & 1.40 & 8,000 & \\
\hline & 2030 & 1.40 & 1,600 & Minimum cost by 2025 \\
\hline \multicolumn{5}{|l|}{ Class $7 \& 8$} \\
\hline \multirow[t]{2}{*}{$\begin{array}{l}\text { Aerodynamic \& Lubrication and } \\
\text { Bearing Improvements }\end{array}$} & 2005 & 1.05 & 2,000 & \\
\hline & 2030 & 1.05 & 400 & Minimum cost by 2030 \\
\hline \multirow[t]{2}{*}{$\begin{array}{l}\text { Low Friction Injectors and Improved } \\
\text { Combusion Efficiency }\end{array}$} & 2008 & 1.06 & 1,500 & \\
\hline & 2030 & 1.06 & 330 & Minimum cost by 2030 \\
\hline \multirow[t]{2}{*}{$\begin{array}{l}\text { Waste Heat Recovery and Fuel Cell } \\
\text { Auxiliary Power Unit }\end{array}$} & 2012 & 1.13 & 3,250 & \\
\hline & 2020 & 1.13 & 845 & Minimum cost by 2030 \\
\hline
\end{tabular}


Exhibit 3-29 illustrates energy savings that are estimated due to the adoption of the OTT supported technologies in medium and heavy trucks. The array of technology options and costs results in significant market penetrations. Greater market penetration and savings occur in Class 7 and 8 trucks due to their dominance in the truck fleet, both in terms of vehicle and Vehicle Miles Travelled.
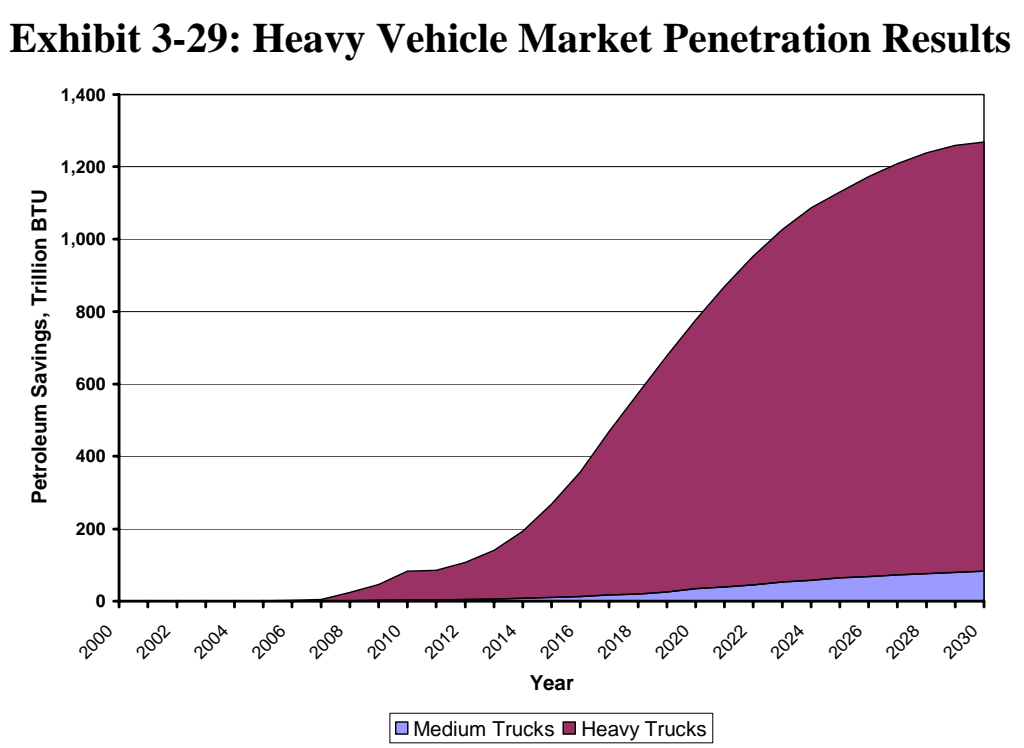

\subsection{Stand-Alone Technologies}

Implicit in the market penetration analysis for light vehicles to this point is the assumption that all of the advanced vehicle technologies being investigated will enter the market and compete not only with conventional light vehicles but also with each other. This reduces the potential sales and resulting vehicle stocks of any one of the advanced vehicle technologies investigated.

In an effort to gauge the effects of this technology competition, the VSCC model was rerun for five separate technologies, as described below in Exhibit 3-30. Tabular comparisons to the OTT Program "Combined Technologies" run are presented in the Exhibits indicated below.

Exhibit 3-30: Stand-Alone Technologies Examined

\begin{tabular}{||c|c|c|}
\hline Exhibit Number & Technology Description & Planning Unit \\
\hline $3-31$ & CNG Dedicated & Vehicle Technologies \\
\hline $3-32$ & Fuel Cell-Gasoline & Vehicle Technologies \\
\hline $3-33$ & Fuel Cell-Gasoline & Vehicle Technologies \\
\hline $3-34$ & Hybrid A (2X) & Vehicle Technologies \\
\hline $3-35$ & Hybrid B (3X) & Vehicle Technologies \\
\hline
\end{tabular}

As expected, the lack of market competition among the technologies that is evidenced in the "Stand-Alone" runs greatly increases the potential energy and petroleum savings, fuel costs and carbon reductions ascribed to each of the technologies, individually. The five separate technologies are shown in Exhibits 3-31 through 3-35. The primary energy displaced, primary oil displaced, energy cost savings, and carbon reductions of each of the OTT technologies and 
for each of the applicable OTT Planning Units taken separately are compared with the same estimated when all technologies are allowed to freely compete with each other. The values presented in Exhibit 3-31 through 3-35 are for light vehicles only (light trucks \& automobiles).

The benefits for all technologies over all planning units are presented in Exhibit 3-36 including all light and heavy vehicles. It is noted that the heavy vehicle parameter values are constant across all stand-alone scenarios presented.

Note that there is a substantial increase in the potential market penetration of any given technology when it is assumed to be competing only with the conventional technology. For instance, in Year 2030, the primary energy saving attributable to stand-alone Hybrid B (3X) is about seventy-two percent $(72 \%)$ greater than the total primary savings when $3 \mathrm{x}$ HEVs are forced to naturally compete with all of the other seven technologies considered.

Exhibit 3-31: Comparison of Stand-Alone Technology Savings with QM (Combined Technology) Savings: Planning Unit: Vehicle Technologies R\&D Technology: Dedicated

\section{CNG Vehicles}

\begin{tabular}{||c|c|c|c|c|c|c|c|c|}
\hline \multirow{2}{*}{ Variable } & \multicolumn{9}{|c|}{ Year } \\
\cline { 2 - 8 } & \multicolumn{2}{|c|}{2005} & \multicolumn{2}{c|}{2010} & \multicolumn{2}{c|}{2020} & \multicolumn{2}{c|}{2030} \\
\cline { 2 - 9 } & $\begin{array}{c}\text { Combined } \\
\text { Estimate } \\
\text { (QM003) }\end{array}$ & $\begin{array}{c}\text { Stand-Alone } \\
\text { Estimate }\end{array}$ & $\begin{array}{c}\text { Combined } \\
\text { Estimate } \\
\text { (QM003) }\end{array}$ & $\begin{array}{c}\text { Stand-Alone } \\
\text { Estimate }\end{array}$ & $\begin{array}{c}\text { Combined } \\
\text { Estimate } \\
\text { (QM003) }\end{array}$ & $\begin{array}{c}\text { Stand-Alone } \\
\text { Estimate }\end{array}$ & $\begin{array}{c}\text { Combined } \\
\text { Estimate } \\
\text { (QM003) }\end{array}$ & $\begin{array}{c}\text { Stand-Alone } \\
\text { Estimate }\end{array}$ \\
\hline $\begin{array}{c}\text { Primary Energy } \\
\text { (quads) }\end{array}$ & 0.000 & 0.000 & 0.000 & 0.000 & 0.000 & 0.000 & 0.000 & 0.000 \\
\hline $\begin{array}{c}\text { Primary Oil Displaced } \\
\text { (quads) }\end{array}$ & 0.001 & 0.002 & 0.077 & 0.237 & 0.376 & 1.206 & 0.611 & 1.904 \\
\hline $\begin{array}{c}\text { Energy Cost Savings } \\
\text { (Billion 1999\$) }\end{array}$ & 0.003 & 0.008 & 0.300 & 0.921 & 1.260 & 4.043 & 5.116 & 15.947 \\
\hline $\begin{array}{c}\text { Carbon Reductions } \\
\text { (mmtons) }\end{array}$ & 0.003 & 0.011 & 0.377 & 1.158 & 1.838 & 5.895 & 2.987 & 9.310 \\
\hline
\end{tabular}


Exhibit 3-32: Comparison of Stand-Alone Technology Savings with QM (Combined Technology) Savings: Planning Unit: Vehicle Technologies R\&D Technology: Fuel Cell Vehicles, Gasoline-Fueled

\begin{tabular}{|c|c|c|c|c|c|c|c|c|}
\hline \multirow{2}{*}{ Variable } & \multicolumn{9}{|c|}{ Year } \\
\cline { 2 - 8 } & \multicolumn{2}{|c|}{2005} & \multicolumn{2}{c|}{2010} & \multicolumn{2}{c|}{2020} & 2030 \\
\cline { 2 - 8 } & $\begin{array}{c}\text { Combined } \\
\text { Estimate } \\
\text { (QM003) }\end{array}$ & $\begin{array}{c}\text { Stand-Alone } \\
\text { Estimate }\end{array}$ & $\begin{array}{c}\text { Combined } \\
\text { Estimate } \\
\text { (QM003) }\end{array}$ & $\begin{array}{c}\text { Stand-Alone } \\
\text { Estimate }\end{array}$ & $\begin{array}{c}\text { Combined } \\
\text { Estimate } \\
\text { (QM003) }\end{array}$ & $\begin{array}{c}\text { Stand-Alone } \\
\text { Estimate }\end{array}$ & $\begin{array}{c}\text { Combined } \\
\text { Estimate } \\
\text { (QM003) }\end{array}$ & $\begin{array}{c}\text { Stand-Alone } \\
\text { Estimate }\end{array}$ \\
\hline $\begin{array}{c}\text { Primary Energy } \\
\text { (quads) }\end{array}$ & 0.000 & 0.000 & 0.002 & 0.005 & 0.368 & 0.838 & 0.954 & 1.958 \\
\hline $\begin{array}{c}\text { Primary Oil Displaced } \\
\text { (quads) }\end{array}$ & 0.000 & 0.000 & 0.002 & 0.005 & 0.382 & 0.838 & 1.206 & 1.958 \\
\hline $\begin{array}{c}\text { Energy Cost Savings } \\
\text { (Billion 1999\$) }\end{array}$ & 0.000 & 0.000 & 0.025 & 0.057 & 3.779 & 8.947 & 15.262 & 31.329 \\
\hline $\begin{array}{c}\text { Carbon Reductions } \\
\text { (mmtons) }\end{array}$ & 0.000 & 0.000 & 0.044 & 0.101 & 7.160 & 16.223 & 21.557 & 37.908 \\
\hline
\end{tabular}

Exhibit 3-33: Comparison of Stand-Alone Technology Savings with QM (Combined Technology) Savings: Planning Unit: Vehicle Technologies R\&D Technology: Fuel Cell Vehicles, Hydrogen-Fueled

\begin{tabular}{|c|c|c|c|c|c|c|c|c|}
\hline \multirow{2}{*}{ Variable } & \multicolumn{7}{|c|}{ Year } \\
\cline { 2 - 8 } & \multicolumn{2}{|c|}{2005} & \multicolumn{2}{c|}{2010} & \multicolumn{2}{c|}{2020} & 2030 \\
\cline { 2 - 9 } & $\begin{array}{c}\text { Combined } \\
\text { Estimate } \\
\text { (QM003) }\end{array}$ & $\begin{array}{c}\text { Stand-Alone } \\
\text { Estimate }\end{array}$ & $\begin{array}{c}\text { Combined } \\
\text { Estimate } \\
\text { (QM003) }\end{array}$ & $\begin{array}{c}\text { Stand-Alone } \\
\text { Estimate }\end{array}$ & $\begin{array}{c}\text { Combined } \\
\text { Estimate } \\
\text { (QM003) }\end{array}$ & $\begin{array}{c}\text { Stand-Alone } \\
\text { Estimate }\end{array}$ & $\begin{array}{c}\text { Combined } \\
\text { Estimate } \\
\text { (QM003) }\end{array}$ & $\begin{array}{c}\text { Stand-Alone } \\
\text { Estimate }\end{array}$ \\
\hline $\begin{array}{c}\text { Primary Energy } \\
\text { (quads) }\end{array}$ & 0.000 & 0.000 & 0.002 & 0.000 & 0.368 & 0.066 & 0.954 & 1.519 \\
\hline $\begin{array}{c}\text { Primary Oil Displaced } \\
\text { (quads) }\end{array}$ & 0.000 & 0.000 & 0.002 & 0.000 & 0.382 & 0.113 & 1.206 & 2.308 \\
\hline $\begin{array}{c}\text { Energy Cost Savings } \\
\text { (Billion 1999\$) }\end{array}$ & 0.000 & 0.000 & 0.025 & 0.000 & 3.779 & 0.213 & 15.262 & 24.303 \\
\hline $\begin{array}{c}\text { Carbon Reductions } \\
\text { (mmtons) }\end{array}$ & 0.000 & 0.000 & 0.044 & 0.000 & 7.160 & 1.395 & 21.557 & 39.094 \\
\hline
\end{tabular}


Exhibit 3-34: Comparison of Stand-Alone Technology Savings with QM (Combined Technology) Savings: Planning Unit: Vehicle Technologies R\&D Technology: Hybrid A-(2X) Vehicles

\begin{tabular}{|c|c|c|c|c|c|c|c|c|}
\hline \multirow{2}{*}{ Variable } & \multicolumn{9}{|c|}{ Year } \\
\cline { 2 - 8 } & \multicolumn{2}{|c|}{2005} & \multicolumn{2}{c|}{2010} & \multicolumn{2}{c|}{2020} & \multicolumn{2}{c|}{2030} \\
\cline { 2 - 8 } & $\begin{array}{c}\text { Combined } \\
\text { Estimate } \\
\text { (QM003) }\end{array}$ & $\begin{array}{c}\text { Stand-Alone } \\
\text { Estimate }\end{array}$ & $\begin{array}{c}\text { Combined } \\
\text { Estimate } \\
\text { (QM003) }\end{array}$ & $\begin{array}{c}\text { Stand-Alone } \\
\text { Estimate }\end{array}$ & $\begin{array}{c}\text { Combined } \\
\text { Estimate } \\
\text { (QM003) }\end{array}$ & $\begin{array}{c}\text { Stand-Alone } \\
\text { Estimate }\end{array}$ & $\begin{array}{c}\text { Combined } \\
\text { Estimate } \\
\text { (QM003) }\end{array}$ & $\begin{array}{c}\text { Stand-Alone } \\
\text { Estimate }\end{array}$ \\
\hline $\begin{array}{c}\text { Primary Energy } \\
\text { (quads) }\end{array}$ & 0.010 & 0.020 & 0.182 & 0.338 & 1.499 & 2.168 & 3.737 & 4.102 \\
\hline $\begin{array}{c}\text { Primary Oil Displaced } \\
\text { (quads) }\end{array}$ & 0.010 & 0.020 & 0.182 & 0.338 & 1.499 & 2.168 & 3.737 & 4.102 \\
\hline $\begin{array}{c}\text { Energy Cost Savings } \\
\text { (Billion 1999\$) }\end{array}$ & 0.105 & 0.217 & 1.991 & 3.696 & 16.005 & 23.151 & 59.788 & 65.634 \\
\hline $\begin{array}{c}\text { Carbon Reductions } \\
\text { (mmtons) }\end{array}$ & 0.190 & 0.395 & 3.525 & 6.544 & 29.020 & 41.977 & 72.343 & 79.417 \\
\hline
\end{tabular}

Exhibit 3-35: Comparison of Stand-Alone Technology Savings with QM (Combined Technology) Savings: Planning Unit: Vehicle Technologies R\&D Technology: Hybrid B (3X) Vehicles

\begin{tabular}{|c|c|c|c|c|c|c|c|c|}
\hline \multirow{2}{*}{ Variable } & \multicolumn{7}{|c|}{ Year } \\
\cline { 2 - 9 } & \multicolumn{2}{|c|}{$\mathbf{2 0 0 5}$} & \multicolumn{2}{|c|}{$\mathbf{2 0 1 0}$} & \multicolumn{2}{c|}{$\mathbf{2 0 2 0}$} & \multicolumn{2}{|c|}{$\mathbf{2 0 3 0}$} \\
\cline { 2 - 9 } & $\begin{array}{c}\text { Combined } \\
\text { Estimate } \\
\text { (QM003) }\end{array}$ & $\begin{array}{c}\text { Stand-Alone } \\
\text { Estimate }\end{array}$ & $\begin{array}{c}\text { Combined } \\
\text { Estimate } \\
\text { (QM003) }\end{array}$ & $\begin{array}{c}\text { Stand-Alone } \\
\text { Estimate }\end{array}$ & $\begin{array}{c}\text { Combined } \\
\text { Estimate } \\
\text { (QM003) }\end{array}$ & $\begin{array}{c}\text { Stand-Alone } \\
\text { Estimate }\end{array}$ & $\begin{array}{c}\text { Combined } \\
\text { Estimate } \\
\text { (QM003) }\end{array}$ & $\begin{array}{c}\text { Stand-Alone } \\
\text { Estimate }\end{array}$ \\
\hline $\begin{array}{c}\text { Primary Energy } \\
\text { (quads) }\end{array}$ & 0.010 & 0.000 & 0.182 & 0.032 & 1.499 & 1.057 & 3.737 & 4.573 \\
\hline $\begin{array}{c}\text { Primary Oil Displaced } \\
\text { (quads) }\end{array}$ & 0.010 & 0.000 & 0.182 & 0.032 & 1.499 & 1.057 & 3.737 & 4.573 \\
\hline $\begin{array}{c}\text { Energy Cost Savings } \\
\text { (Billion 1999\$) }\end{array}$ & 0.105 & 0.000 & 1.991 & 0.349 & 16.005 & 11.283 & 59.788 & 73.173 \\
\hline $\begin{array}{c}\text { Carbon Reductions } \\
\text { (mmtons) }\end{array}$ & 0.190 & 0.000 & 3.525 & 0.617 & 29.020 & 20.459 & 72.343 & 88.539 \\
\hline
\end{tabular}


The individual benefits of the five (5) stand-alone results compared to the Total QM 2003 are shown in Exhibit 3-36. The combined program results in higher benefits than the individual technologies. The hybrid technologies show the best stand-alone performance, realizing about eighty percent $(80 \%)$ of the combined program's primary oil displacement.

Exhibit 3-36: Comparison of Stand-Alone Technology Savings with QM (Combined Technology) Savings: Planning Unit: All OTT Technology: All

\begin{tabular}{|c|c|c|c|c|c|c|}
\hline \multirow{2}{*}{ Variable } & \multicolumn{5}{|c|}{ Year 2030 Comparisons } & \multirow{2}{*}{ Total QM } \\
\cline { 2 - 7 } & \multicolumn{2}{|c|}{ Stand-Alone Technologies (not additive) } \\
\cline { 2 - 7 } & $\begin{array}{c}\text { CNG } \\
\text { Dedicated }\end{array}$ & $\begin{array}{c}\text { Fuel Cell- } \\
\text { Gasoline }\end{array}$ & $\begin{array}{c}\text { Fuel Cell- } \\
\text { Hydrogen }\end{array}$ & Hybrid A & Hybrid B & 2003 \\
\hline Primary Energy (quads) & 4.184 & 6.357 & 5.870 & 8.406 & 8.890 & 10.326 \\
\hline $\begin{array}{c}\text { Primary Oil Displaced } \\
\text { (quads) }\end{array}$ & 6.447 & 6.716 & 7.105 & 8.765 & 9.250 & 11.637 \\
\hline $\begin{array}{c}\text { Energy Cost Savings } \\
\text { (Billion 1999\$) }\end{array}$ & 34.336 & 53.160 & 45.363 & 85.935 & 93.693 & 134.217 \\
\hline $\begin{array}{c}\text { Carbon Reductions } \\
\text { (mmtons) }\end{array}$ & 91.563 & 124.326 & 125.643 & 163.983 & 173.371 & 204.850 \\
\hline
\end{tabular}

note: these numbers include all OTT savings estimates-including heavy vehicles

\subsection{Benefits Estimates}

The results of the analysis to determine the benefits associated with the OTT planning units are presented here and in the appendices. The benefits estimation methodology and assumptions are described. Benefits considered include:

- Petroleum and energy benefits, and

- Economic and environmental benefits.

The Quality Metrics results are presented in their entirety in Appendix A.

\subsection{Petroleum and Other Energy Benefits Analysis}

Annual petroleum displacement and emission reductions are presented in this section. They are calculated by projecting the miles traveled by each model year's conventional vehicles, their petroleum use and their emissions; and then subtracting from these estimates the related projections for advanced technology vehicles. The methodology takes into account vehicle stocks and usage characteristics based on work by Mintz (Ref 10) and Greene and Rathi (Ref. 11). Projections of transportation fuels available from biomass affect the estimated supply of alcohol fuels as discussed below. 


\subsubsection{Biomass Assumptions}

Ethanol fuel use estimates are based on supply projections provided by the Office of Fuels Development (Ref. 12). The technology timeline for the program is summarized as follows.

- 2005 - produce prototypical cellulose enzymes that would cost no more than 9 cents per gallon ethanol

- 2006 - validate new yeasts for converting at least four types of biomass sugars to ethanol

- 2010 - complete pilot plant testing of technology for producing ethanol from residues at $\$ 1.07$ per gallon

- 2015 - develop novel biomass pretreatment and enzyme recycle systems

- 2020 - commercialize advanced bio-energy crop for concurrent production of ethanol and high-value chemicals

- 2030+ - demonstrate conversion efficiency of at least 100 gallons of ethanol per ton of dry biomass

The Biomass Ethanol Program supports research, development, and demonstration (RD\&D) of ethanol production technology. In the near-term, the program emphasis is on collaboration with ethanol production technology firms and ethanol producers to demonstrate near term biomass ethanol technologies, and investigate opportunities for adding cellulosic feedstock to the existing base of corn kernels feedstock. In the mid and long term, the Program

Demand for ethanol from biomass may also be accelerated by efforts of several states to eliminate the use of Methyl Tertiary Butyl Either (MTBE). California, New York and some smaller states have decided to phase out MTBE (a gasoline additive widely used to reduce air pollutant levels) in a few years. Several other states are considering phasing out or restricting the use of MTBE.

Exhibit 4-1: Biofuels Supply Projection (Ref. 12)

Biomass ethanol can play an important role in the nation's greenhouse gas (GHG) mitigation strategy due to its renewable resource characteristics - the carbon released during combustion comes from the carbon withdrawn from the biosphere during feedstock growth. Consequently, the total fuel cycle produces nearzero net carbon dioxide emissions. Recent estimates show that using cellulosic ethanol reduces GHG emissions by more than 80 percent compared with reformulated

\begin{tabular}{|c|c|c|c|}
\hline ITEM & 2010 & 2020 & 2030 \\
\hline $\begin{array}{l}\text { Cellulosic ethanol use, Million barrels } \\
\text { per day (gasoline equivalent) }\end{array}$ & 0.085 & 0.5 & 1.5 \\
\hline Cellulosic ethanol use, Billion Gal./Yr. & 2 & 11.5 & 34.5 \\
\hline $\begin{array}{l}\text { Savings, Million metric tonnes of carbon } \\
\text { equivalent }\end{array}$ & 3.2 & 18.4 & 55.2 \\
\hline $\begin{array}{l}\text { Biomass conversion, gallons of ethanol } \\
\text { per dry ton biomass }\end{array}$ & 84 & 91 & 98 \\
\hline $\begin{array}{l}\text { Residues and bio-energy crops per year, } \\
\text { Million dry tons (MMT) }\end{array}$ & 23.8 & 126 & 352 \\
\hline Residues per year, MMT & 23.8 & 123.4 & 210 \\
\hline Bio-energy crops per year, MMT & 0 & 2.6 & 142 \\
\hline $\begin{array}{l}\text { Annual bio-energy crop yield, dry tons } \\
\text { per acre }\end{array}$ & 5.7 & 6.6 & 7.7 \\
\hline $\begin{array}{l}\text { Land area for bio-energy crops, million } \\
\text { acres }\end{array}$ & 0 & 0.4 & 18.7 \\
\hline
\end{tabular}
gasoline. 
The cellulosic ethanol goals are indicated in Exhibit 4-1. By 2010, 2 billion gallons of ethanol will be supplied for transportation. This is expected to grow to 11.5 billion gallons by 2020 , and expand to 34.5 billion gallons by 2030 .

The sources for this ethanol will initially be agricultural residues, but by 2030 around forty percent (40\%) will be derived from bio-energy crops.

Cost projections are shown in Exhibit 4-2. Through Year 2020 ethanol will be consumed primarily the E10/E5.7 market. Beyond 2020, 14 billion gallons of ethanol will continue to be used each year in the E10/E5.7 market, whereas amounts greater than 14 billion gallons will be used in $\mathrm{E} 85$ or $\mathrm{E} 95$ for dedicated ethanol vehicles.

\section{Exhibit 4-2: Biomass Ethanol Cost and Price projections (1999\$)}

\begin{tabular}{||l|c|c|c||}
\hline \multicolumn{1}{|c|}{ ITEM } & $\mathbf{2 0 1 0}$ & $\mathbf{2 0 2 0}$ & $\mathbf{2 0 3 0}$ \\
\hline Production cost & 1.07 & 0.83 & 0.68 \\
\hline Federal incentive & -0.35 & -0.22 & -0.1 \\
\hline Distribution costs & 0.16 & 0.16 & 0.14 \\
\hline Federal \& state taxes & 0.32 & 0.25 & 0.2 \\
\hline Price/gal ethanol & 1.2 & 1.02 & 0.92 \\
\hline Price/GGE & comp & comp & 1.38 \\
\hline
\end{tabular}




\subsubsection{Fuel Choice for Flex-Fuel Vehicles}

Alternative fuel consumer utility values are compared to values for conventional fuels, when fuel choice estimations are made. Exhibit 4-3 shows the market share that an alternative fuel will achieve given a specified price and availability relative to gasoline. This graph illustrates the relationship between fuel availability and fuel price. For example, at fifty percent (50\%) availability and a zero cost increment, the alternative fuel should be chosen forty-five percent $(45 \%)$ of the time (Point A). If the price increment is decreased twenty percent $(20 \%)$, it is estimated the alternative fuel will be chosen nearly $90 \%$ of the time (Point B). Whereas, if fuel availability is increased to seventy percent $(70 \%)$ only marginal increases in alternative fuel selection occur (to $49 \%$ at Point $\mathrm{C}$ ). The calculations for this graph assume no range penalty for using the alternative fuel.

\section{Exhibit 4-3: Alternative Fuel Market Share as a Function of Fuel Availability and Fuel Price (Ref. 13)}
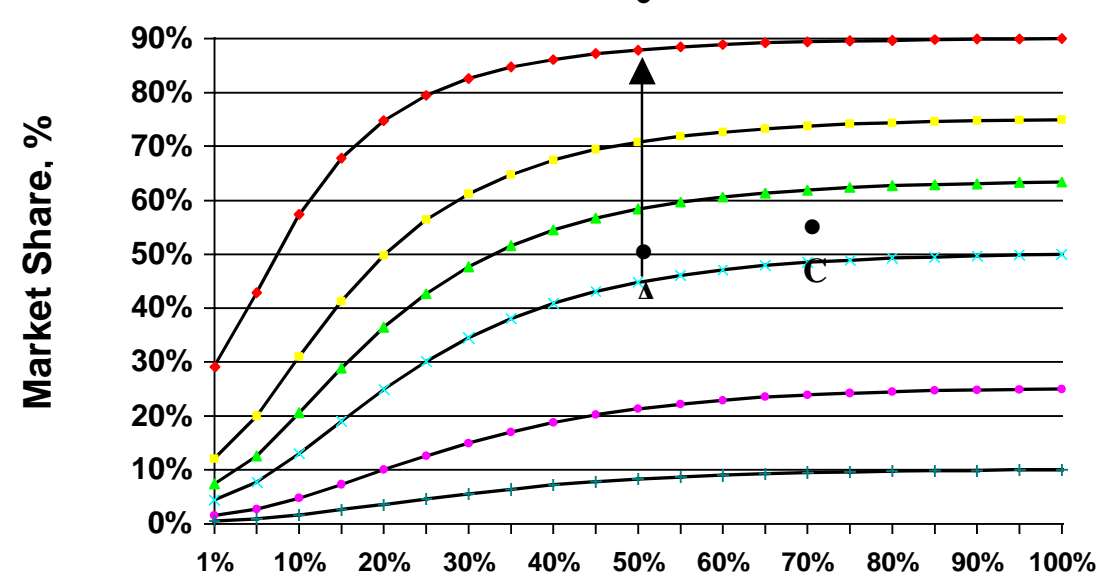

Fuel Price Delta

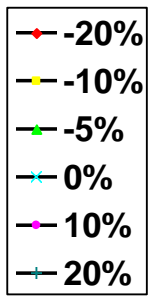

Points A, B, and C are explained ilability

\subsubsection{Estimates of the Value of Reducing Imported Oil}

Many researchers have developed estimates of the magnitude and cause of cost premiums associated with importing oil. The oil import premium exists because the market price of oil does not cover the societal cost incurred by importing. In order to calculate the value of an alternative to imported oil, one must add the market price of oil to the import premium. The "categories" of the oil import premiums, the rationale for including an oil import premium, and the range of estimates for the value of the oil import premium are explained in this section.

\section{Definitions of the Components of an Imported Oil Premium}

Externalities associated with imported oil can be defined as follows: demand costs ("market power" or monopsony effects, plus indirect effects such as inflation and balance of payments), disruption costs (economic losses due to price spikes), direct military costs (expenditures to 
maintain a military presence in oil producing regions), and environmental costs (costs due to oil spills and other environmental problems associated with importing oil). The demand and disruption costs are the most commonly used measure of an oil import premium (Ref. 14).

Demand costs can be broken into a direct and indirect component. The direct component is known as the "market power" or monopsony effects. Monopsony costs occur when the increase in the demand for imported oil causes world oil prices to rise, thus increasing the costs of all imports, not just the incremental demand. Not only is the added cost borne by the demander responsible for the increase, but by all importers equally. The market power premium can be illustrated by a simple example.

Suppose the U.S. were importing 5.5 million barrels of oil a day at a price of $\$ 30$ per barrel. Then the daily import bill would be $\$ 165$ million. If increasing imports to 6.0 million barrels per day causes prices to rise to $\$ 31$ per barrel, the daily import bill becomes $\$ 186$ million. In this situation, the importing country bears an additional cost of $\$ 21$ million per day in order to import an additional 0.5 million barrels per day. The cost to the economy is $\$ 42$ per additional barrel of oil imported. Since the individual oil importers initially pay only $\$ 30$ per barrel, the remainder -$\$ 12$ per barrel -- is a cost not borne by those who decide to import more oil. In this case, the market power premium is $\$ 12$ per barrel.

Indirect costs are the macroeconomic costs of importing oil such as inflation impacts, lowering the level of savings, and terms of trade impacts. Imported oil bills increase the current account deficit in the U.S. balance of trade, leading to an excess supply of U.S. dollars in the foreign exchange market and thus lowering the buying power of U.S. consumers. Higher imported oil costs can lead to "structural" inflation that leads to adverse macroeconomic conditions.

Disruption or "security" costs can also be broken into direct and indirect components. The direct component is similar to the above direct component because it is the monopsony affect that occurs when prices increase due to a disruption. The indirect, or macroeconomic, component of disruption costs are associated with the depressed aggregate demand caused by the disruption and the accompanying higher inflation and unemployment.

The demand and disruption costs are traditional components of the calculation of an oil import premium. Somewhat untraditional and harder to quantify, additional components of the oil import premium are direct military expenditures and environmental costs. The military expenditures are some fraction of the costs to the U.S. to maintain a military presence in the Middle East to ensure continued access to oil. The environmental costs are less straightforward - they primarily include the costs of oil spills and emissions from oil combustion. At this time, we have no estimates of the environmental costs. There are a variety of estimates of military costs based on the amount of military resources dedicated to the Persian Gulf region. Oak Ridge National Laboratory conducted a literature review and assessment of military costs to assure the supply of oil imports to the U.S. The total estimated cost of defending the Middle East Oil supplies is estimated to be about $\$ 32$ billion per year in Reference 15 . This is a difficult value to estimate, since it must be calculated based on allocations of costs to meet various needs. In this respect there is no "real" military cost other than that which is allocated and all allocation schemes are highly subjective. The range of estimates reviewed by Reference 15 is about a factor of ten. 
The military cost of Middle East oil is borne by all and it is therefore reasonable to assign this cost to all petroleum consumed in the country whether from domestic, OPEC, non-OPEC or Middle East sources. Since the total U.S. petroleum demand is about thirty-seven (37) Quads or about 6.4 billion barrels per year, the "effective" cost of the military support of the Middle East allocated over all petroleum is about $\$ 4.78$ per barrel. For purposes of this analysis, a benchmark "military cost" charge of $\$ 5.00$ per barrel (about eleven (11) cents per gallon of gasoline) has been assumed.

\subsubsection{Range of Estimates of Imported Oil Premium}

The literature suggests that there are indirect economic costs and economic security costs associated with imported oil at prices influenced by a cartel. These costs are not captured in the gross domestic product (GDP) estimates from the economic models that are used in our analysis. Therefore, these costs need to be subtracted from any GDP estimate.

Several types of costs are not captured in the standard economic valuations. These are:

- Demand costs that are caused by the oil price increases that will occur when U.S. demand increases. This will have an effect on GDP.

- Disruption costs, which reflect the expected economic costs of sudden shifts in oil price or availability due to possible political unrest in the Middle East. Also, unpredictable oil costs tend to suppress innovations that might otherwise have been implemented, thereby reducing petroleum consumption.

- Other costs which include the military costs of protecting Middle East oil supplies and environmental costs associated with foreign oil production and transport.

Exhibit 4-4 identifies a range of estimates of an oil import premium (the market price of oil plus the oil import premium equals the value of reducing oil imports). They range from $\$ 12$ to more than \$225 depending on what is included in the estimate, the price of oil, and other assumptions. These values do not indicate whether or not the price of imported oil has an impact on its premium.

The suggested cost associated with the use of imported oil, based on a subjective evaluation of the alternative estimates (Exhibit 4-4), and placing greater weight on more recent estimates, is a nominal $\$ 5.25 /$ barrel (1999 $\$$ ). This cost is in addition to the military cost of $\$ 5 /$ barrel discussed previously. 
Exhibit 4-4: Value of Reducing Imported Oil (1999 \$ per Barrel)

\begin{tabular}{|c|c|c|c|c|c|}
\hline \multirow[b]{2}{*}{ Source } & & \multicolumn{3}{|c|}{ Value, $1999 \$$} & \multirow[b]{2}{*}{ Notes } \\
\hline & & $\begin{array}{l}\text { Demand } \\
\text { Costs }\end{array}$ & $\begin{array}{l}\text { Disruption } \\
\text { Costs }\end{array}$ & $\begin{array}{l}\text { Total } \\
\text { Costs }\end{array}$ & \\
\hline Stobaugh and Yergin (1979) & $\begin{array}{l}\text { Low } \\
\text { High }\end{array}$ & $\begin{array}{r}\$ 34 \\
\$ 127\end{array}$ & & $\begin{array}{r}\$ 34 \\
\$ 127\end{array}$ & \\
\hline Stobaugh and Yergin (1980) & $\begin{array}{l}\text { Low } \\
\text { High }\end{array}$ & $\begin{array}{r}\$ 65 \\
\$ 236\end{array}$ & & $\begin{array}{r}\$ 65 \\
\$ 236 \\
\end{array}$ & \\
\hline Lemon (1979) & & $\$ 66$ & $\$ 7$ & $\$ 74$ & \\
\hline Lemon (1980) & & $\$ 104$ & $\$ 26$ & $\$ 130$ & \\
\hline Nordhaus (1980) & $\begin{array}{l}\text { Low } \\
\text { High }\end{array}$ & $\$ 47$ & $\begin{array}{l}\$ 19 \\
\$ 34\end{array}$ & $\begin{array}{l}\$ 19 \\
\$ 81\end{array}$ & \\
\hline Plummer (1981) & $\begin{array}{l}\text { Low } \\
\text { High }\end{array}$ & $\begin{array}{l}\$ 12 \\
\$ 12\end{array}$ & $\begin{array}{r}\$ 6 \\
\$ 40 \\
\end{array}$ & $\begin{array}{l}\$ 19 \\
\$ 52\end{array}$ & \\
\hline Hogan (1981) & $\begin{array}{l}\text { Low } \\
\text { High }\end{array}$ & $\$ 49$ & $\$ 17$ & $\begin{array}{r}\$ 0 \\
\$ 66 \\
\end{array}$ & \\
\hline EMF 6 (1981) & $\begin{array}{l}\text { Low } \\
\text { High }\end{array}$ & $\begin{array}{l}\$ 12 \\
\$ 26\end{array}$ & $\$ 9$ & $\begin{array}{l}\$ 12 \\
\$ 35\end{array}$ & $\begin{array}{l}\text { Based on } 9 \text { different } \\
\text { models }\end{array}$ \\
\hline TOTALS & $\begin{array}{l}\text { Low } \\
\text { Avg. } \\
\text { High }\end{array}$ & $\begin{array}{r}\$ 12 \\
\$ 61 \\
\$ 236\end{array}$ & $\begin{array}{r}\$ 7 \\
\$ 20 \\
\$ 40\end{array}$ & $\begin{array}{r}12 \\
\$ 73 \\
\$ 236\end{array}$ & \\
\hline
\end{tabular}

\subsubsection{Petroleum Reduction Estimates}

Exhibit 4-5 shows the energy and oil that will be displaced as a result of the OTT programs discussed in this report. It can be seen that the total oil displacement that will occur in the year 2030 is about 5.5 million barrels per day, about $27.5 \%$ of the projected total transportation energy use.

The energy use effects of current zero emission vehicle (ZEV) mandates and EPACT requirements are indicated in Exhibit 4-6. Exhibit 4-7 shows that the OTT programs will have the effect of stabilizing the gap between domestic petroleum production and demand. The values used to generate Exhibit 4-7 can be found in tabular form in Appendix A, Table A-8. 
Exhibit 4-5: Energy Displaced

\begin{tabular}{|c|c|c|c|c|c|c|c|c|}
\hline \multirow[t]{2}{*}{ Technology } & \multicolumn{4}{|c|}{$\begin{array}{c}\text { Primary Energy Displaced } \\
\text { MMBDOE }\end{array}$} & \multicolumn{4}{|c|}{$\begin{array}{c}\text { Primary Oil Displaced } \\
\text { MMBDOE }\end{array}$} \\
\hline & Year 2005 & Year 2010 & Year 2020 & Year 2030 & Year 2005 & Year 2010 & Year 2020 & Year 2030 \\
\hline Vehicle Technologies R\&D & 0.013 & 0.240 & 1.706 & 3.388 & 0.017 & 0.249 & 1.750 & 3.583 \\
\hline Hybrid Systems R\&D & 0.005 & 0.086 & 0.708 & 1.765 & 0.005 & 0.086 & 0.708 & 1.765 \\
\hline Fuel Cell R\&D & 0.000 & 0.001 & 0.174 & 0.451 & 0.000 & 0.001 & 0.181 & 0.570 \\
\hline Advanced Combustion R\&D & 0.001 & 0.098 & 0.391 & 0.435 & 0.001 & 0.098 & 0.391 & 0.435 \\
\hline Car CIDI & 0.000 & 0.063 & 0.223 & 0.229 & 0.000 & 0.063 & 0.223 & 0.229 \\
\hline Light Truck CIDI & 0.000 & 0.035 & 0.169 & 0.206 & 0.000 & 0.035 & 0.169 & 0.206 \\
\hline Electric Vehicle R\&D & 0.007 & 0.016 & 0.067 & 0.139 & 0.011 & 0.024 & 0.103 & 0.215 \\
\hline Household EV & 0.000 & 0.001 & 0.042 & 0.105 & 0.000 & 0.002 & 0.064 & 0.163 \\
\hline EPAct ZEV Mandates & 0.007 & 0.014 & 0.025 & 0.034 & 0.011 & 0.022 & 0.039 & 0.052 \\
\hline Heavy Vehicle Systems R\&D & 0.000 & 0.039 & 0.366 & 0.598 & 0.000 & 0.039 & 0.366 & 0.598 \\
\hline Class 3-6 & 0.000 & 0.001 & 0.016 & 0.039 & 0.000 & 0.001 & 0.016 & 0.039 \\
\hline \begin{tabular}{|c|} 
Class $7 \& 8$ \\
\end{tabular} & 0.000 & 0.038 & 0.350 & 0.559 & 0.000 & 0.038 & 0.350 & 0.559 \\
\hline Materials Technologies & 0.000 & 0.003 & 0.044 & 0.111 & 0.000 & 0.003 & 0.047 & 0.130 \\
\hline Propulsion System Materials & 0.000 & 0.000 & 0.000 & 0.000 & 0.000 & 0.000 & 0.000 & 0.000 \\
\hline Light Vehicle Materials & 0.000 & 0.003 & 0.044 & 0.111 & 0.000 & 0.003 & 0.047 & 0.130 \\
\hline Electric Vehicle & 0.000 & 0.000 & 0.004 & 0.010 & 0.000 & 0.000 & 0.006 & 0.016 \\
\hline Hybrid Vehicle & 0.000 & 0.003 & 0.021 & 0.051 & 0.000 & 0.003 & 0.021 & 0.051 \\
\hline Fuel Cell Vehicle & 0.000 & 0.000 & 0.019 & 0.050 & 0.000 & 0.000 & 0.020 & 0.063 \\
\hline Technology Deployment & 0.000 & 0.000 & 0.000 & 0.000 & 0.112 & 0.144 & 0.290 & 0.406 \\
\hline Household CNG & 0.000 & 0.000 & 0.000 & 0.000 & 0.000 & 0.036 & 0.178 & 0.289 \\
\hline EPAct Fleet & 0.000 & 0.000 & 0.000 & 0.000 & 0.112 & 0.108 & 0.112 & 0.118 \\
\hline Fuels Development & 0.008 & 0.080 & 0.460 & 1.379 & 0.008 & 0.080 & 0.460 & 1.379 \\
\hline Blends and Extenders & 0.006 & 0.073 & 0.450 & 0.758 & 0.006 & 0.073 & 0.450 & 0.758 \\
\hline Flex-Fuel & 0.002 & 0.007 & 0.010 & 0.621 & 0.002 & 0.007 & 0.010 & 0.621 \\
\hline Dedicated Conventional & 0.000 & 0.000 & 0.000 & 0.000 & 0.000 & 0.000 & 0.000 & 0.000 \\
\hline Fuel Cell & 0.000 & 0.000 & 0.000 & 0.000 & 0.000 & 0.000 & 0.000 & 0.000 \\
\hline Total & 0.021 & 0.323 & 2.210 & 4.878 & 0.137 & 0.476 & 2.546 & 5.497 \\
\hline Baseline (AEO 01 -Transportation) & 14.17 & 15.54 & 18.06 & 20.83 & 13.73 & 14.99 & 17.37 & 19.99 \\
\hline Percent Reduction & $0.1 \%$ & $2.1 \%$ & $12.2 \%$ & $23.4 \%$ & $1.0 \%$ & $3.2 \%$ & $14.7 \%$ & $27.5 \%$ \\
\hline
\end{tabular}

Exhibit 4-6: ZEV and EPACT Oil Reductions

\begin{tabular}{||l|c|c|c|c|c|}
\hline \multicolumn{1}{|c|}{ Program } & $\mathbf{2 0 0 5}$ & $\mathbf{2 0 1 0}$ & $\mathbf{2 0 1 5}$ & $\mathbf{2 0 2 0}$ & $\mathbf{2 0 3 0}$ \\
\hline $\begin{array}{l}\text { ZEV Mandates } \\
\text { (Trillion BTU) }\end{array}$ & 19.67 & 44.35 & 65.90 & 80.15 & 106.78 \\
\hline $\begin{array}{l}\text { EPACT } \\
\text { (Trillion BTU) }\end{array}$ & 3.78 & 2.68 & 2.70 & 2.88 & 3.20 \\
\hline $\begin{array}{l}\text { Total } \\
\text { Trillion BTU) }\end{array}$ & 23.45 & 47.03 & 68.60 & 83.03 & 109.98 \\
\hline
\end{tabular}


Exhibit 4-7: Transportation Petroleum Use Projection

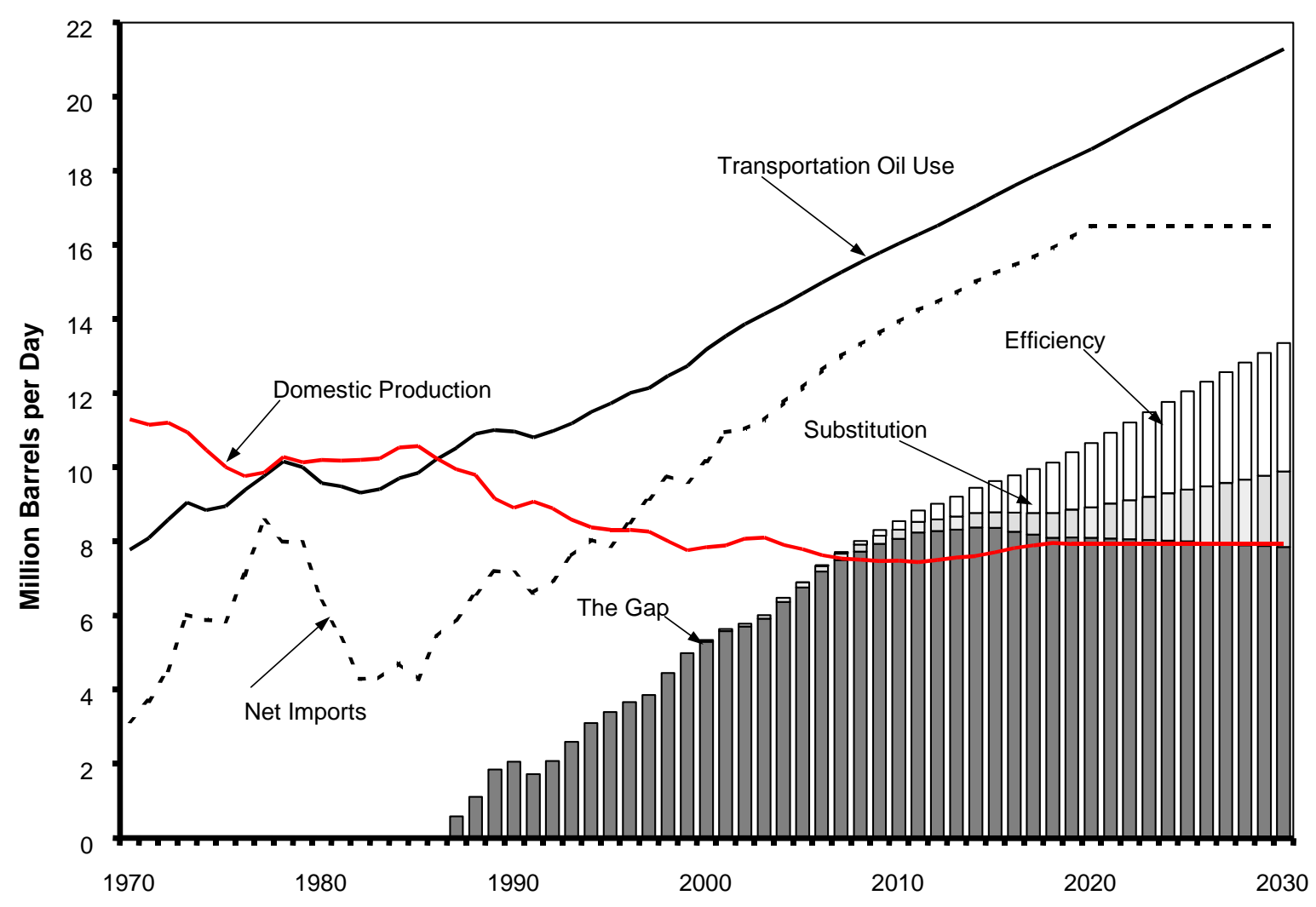

\subsection{Economic and Environmental Benefits Analysis Results}

In this section, economic and environmental benefits analyses are presented. The scope of the OTT Impacts Assessments contains analyses that supplement those required by QM. These include total fuel cycle criteria and carbon pollutant reductions, while QM requires direct carbon, hydrocarbon, $\mathrm{CO}$, and $\mathrm{NO}_{\mathrm{x}}$ reduction benefits only.

Employment impacts developed using the Economic Spreadsheet Model (ESM) are developed first; this is followed by a discussion of the methodology for estimating vehicle infrastructure capital requirements. The next section addresses criteria pollutant emissions reduction values. Finally, estimating reductions in carbon emissions from the commercial utilization of OTTsponsored technologies is discussed.

\subsubsection{Economic Benefit Estimates}

The ESM is a spreadsheet model that estimates employment and GDP impacts of OTT's programs. The spreadsheet takes economic impacts from the Quality Metrics process and applies them to economic multipliers, developed with Department of Commerce data, to estimate employment impacts of OTT technologies. Key inputs to the model are:

1) Incremental vehicle cost of OTT technologies (if any);

2) Money spent on alternative fuels associated with OTT's technologies; and 
3) Money saved from decreased spending on gasoline or diesel.

Exhibit 4-8 shows a summary of job impacts by sector of the economy. The multipliers used to provide these numbers are industry specific at an aggregate level. The multipliers are derived from the Regional Input-Output Modeling System (RIMS II) developed by the Bureau of Economic Analysis (BEA), U.S. Department of Commerce. They are based on an aggregate U.S. industry structure and updated with 1995 regional data. A discussion of how the multipliers were calculated is explained in Appendix B.

The multipliers are used to calculate net jobs and GDP by multiplying them with the spending quantities associated with the advanced technologies. Expenditures considered are:

- Spending on vehicles;

- Decreased spending on oil;

- Fuel cost savings; and

- Increased spending on alternative fuels.

Exhibit 4-8: Employment Impacts by Sector of Economy (Jobs)

\begin{tabular}{|l|r|r|r|r||}
\hline \multicolumn{1}{|c|}{ Industry } & $\mathbf{2 0 0 0}$ & $\mathbf{2 0 1 0}$ & \multicolumn{1}{c|}{$\mathbf{2 0 2 0}$} & \multicolumn{1}{c|}{$\mathbf{2 0 3 0}$} \\
\hline Farm, forestry, and fishery products & 17 & 1,156 & 36,600 & 91,794 \\
\hline Mining & -159 & $-25,564$ & $-146,169$ & $-409,814$ \\
\hline Construction & -11 & $-1,517$ & $-6,406$ & $-19,249$ \\
\hline Durable goods & 255 & 94,102 & 225,929 & 215,369 \\
\hline Nondurable goods & 60 & 16,067 & 66,250 & 120,039 \\
\hline Transportation and public utilities & 33 & 8,493 & 35,732 & 74,048 \\
\hline Wholesale trade & 59 & 18,426 & 55,885 & 81,750 \\
\hline Retail trade & 73 & $-6,183$ & 57,663 & 315,526 \\
\hline Finance, insurance, \& real estate & 12 & $-9,693$ & 7,812 & 119,165 \\
\hline Service & 203 & $-9,900$ & 165,707 & 831,926 \\
\hline Private households & 4 & $-1,351$ & 3,040 & 25,641 \\
\hline Total & 546 & 84,036 & 502,041 & $1,446,195$ \\
\hline
\end{tabular}

Exhibit 4-8 shows that the mining industry loses jobs while most other industries gain jobs. Advanced transportation technologies create jobs, in large part, because they induce spending in areas with larger multipliers than areas where spending would have occurred. The mining industry loses jobs because the reduced spending on oil affects the mining industry more than other industries. Job impacts attributable to the individual technologies fostered by OTT are indicated in Exhibit 4-9. 
Exhibit 4-9: Employment Impacts by Technology (Jobs)

\begin{tabular}{|l|r|r|r|r||}
\hline \multicolumn{1}{|c|}{ Technology } & $\mathbf{2 0 0 0}$ & $\mathbf{2 0 1 0}$ & $\mathbf{2 0 2 0}$ & $\mathbf{2 0 3 0}$ \\
\hline Alternative Fuel Vehicles & 37 & 5,071 & 19,882 & 73,343 \\
\hline Biofuels & 0 & 9,373 & 53,288 & 78,627 \\
\hline Electric Vehicle R\&D & 533 & 14,346 & 33,777 & 102,311 \\
\hline Fuel Cell R\&D & 0 & -158 & 33,231 & 179,211 \\
\hline Heavy Duty R\&D & -24 & 7,456 & 70,911 & 115,868 \\
\hline Hybrid Vehicle R\&D & 0 & 15,334 & 154,101 & 619,922 \\
\hline Light Duty Engine--car & 0 & 21,080 & 71,736 & 124,784 \\
\hline Light Duty Engine--truck & 0 & 10,956 & 53,725 & 99,881 \\
\hline Lightweight Materials R\&D & 0 & 576 & 11,388 & 52,250 \\
\hline Totals & 546 & 84,036 & 502,041 & $1,446,195$ \\
\hline
\end{tabular}

By 2020, hybrid vehicle production has the most significant benefit to job creation. In 2030, virtually all of the OTT-supported technologies are shown to have significant employment benefits, with hybrids continuing to have the most significant effect, followed by fuel cell vehicles, and heavy vehicles.

The increase in GDP is shown in Exhibit 4-10. Like the increase in jobs, the increase in GDP was calculated by applying the multipliers discussed above and in Appendix B. While the impact on GDP appears to be large, compared to the baseline, it represents an effect of less than one percent $(1 \%)$ of the U.S. economy.

Exhibit 4-10: GDP Effects (Millions of \$1999)

\begin{tabular}{|c|c|c|c|c|}
\hline GDP Impact by Industry & 2000 & 2010 & 2020 & 2030 \\
\hline Alternative Fuel Vehicles & $\$ 0$ & $\$ 926$ & $\$ 5,177$ & $-\$ 744$ \\
\hline Biofuels & $-\$ 1$ & $\$ 878$ & $\$ 1,761$ & $\$ 659$ \\
\hline Electric Vehicle R\&D & $-\$ 16$ & $\$ 939$ & $\$ 4,402$ & $\$ 4,001$ \\
\hline Fuel Cell R\&D & $\$ 0$ & $\$ 1,037$ & $\$ 13,052$ & $\$ 1,473$ \\
\hline Heavy Duty R\&D & $\$ 60$ & $\$ 37$ & $-\$ 1,741$ & $-\$ 3,089$ \\
\hline Hybrid Vehicle R\&D & $\$ 0$ & $\$ 11,869$ & $\$ 17,661$ & $\$ 296$ \\
\hline Light Duty Engine--car & $\$ 0$ & $\$ 2,464$ & $\$ 564$ & $-\$ 906$ \\
\hline Light Duty Engine--truck & $\$ 0$ & $\$ 2,801$ & $\$ 2,161$ & $\$ 1,474$ \\
\hline Lightweight Materials R\&D & $\$ 0$ & $\$ 593$ & $\$ 2,450$ & $\$ 694$ \\
\hline Total & $\$ 43$ & $\$ 21,543$ & $\$ 45,487$ & $\$ 3,858$ \\
\hline
\end{tabular}




\subsubsection{Vehicle Infrastructure Capital Requirements}

This section describes the vehicle infrastructure capital requirements to support advanced technology vehicle commercial introduction. The basic methodology, rationale for production volume cost estimates, and capital constraints of auto manufacturers are addressed.

A rough estimate of capital investment necessary to produce advanced light vehicles was made. The methodology consists of three (3) steps:

1. Estimate vehicles sold per technology by year;

2. Estimate production facility costs on a volume basis by technology;

3. Apply the production facility cost factor to vehicle sales that exceed the sales in the previous year for each technology.

Step 1 is based on the vehicle choice model results--the vehicle choice model provides sales estimates by technology per year. Step 2 is from empirical data and is discussed in more detail below. Step 3 is a simple way to estimate the incremental costs. In general, it is anticipated that a minimum of 50,000 to 100,000 vehicle sales per year are required in order for the production of an advanced technology or alternative fuel vehicle to be sustained.

\section{$\underline{\text { Production Facility Costs }}$}

To estimate production facility costs, several estimates to develop new car lines were reviewed. Examples used include (Refs. 16-24):

- General Motors has constructed a new production plant in Lansing, Michigan. The plant's estimated cost is $\$ 560$ million and will produce 150,000 units per year (2002).

- Honda Manufacturing of Alabama vehicle and engine production, and stamping plant cost about $\$ 1$ billion. The plant will produce 120,000 vehicles and six-cylinder engines. Operations include: stamping, welding, painting, plastic injection molding, casting machining, and subassembly (2002).

- Saturn production plant costs of $\$ 4.5$ billion to produce 500,000 vehicles per year.

- Ford Contour costs to retool nine assembly plants for new model costing $\$ 6$ billion to produce 700,000 per year.

- Various estimates of engine and transmission plants indicating costs of about $\$ 300$ million to build facilities with production outputs of 100,000 engines/transmissions per year.

- A Congressional Research Service report estimating changeover costs (for producing more efficient vehicles and engine) of $\$ 1.5$ billion to $\$ 3.0$ billion per car line $(250,000$ to 300,000 vehicles per year).

Based on the above information, the following production infrastructure costs by type of vehicle were estimated: 
- CIDI and SIDI: $\$ 300$ million per 100,000 vehicles. This cost is based primarily on cost to build a new engine plant. It is assumed that these technologies would be options for an existing production line.

- CNG Vehicles: $\$ 700$ million per 100,000 vehicles. This cost is based on engine costs plus supporting fuel systems costs such as different on-board tanks and fuel supply systems. It is assumed that CNG vehicles would be adapted from existing car lines.

- Electric, hybrid, and fuel cell vehicles: $\$ 2$ billion per 100,000 vehicles. This cost is based on new assembly plant, engine, battery, motor, and supporting technology plant costs. It is assumed that these vehicles would be totally new car lines.

Exhibit 4-11 shows capital infrastructure costs associated with producing advanced automotive technologies. It shows that expenditures peak in 2011 at $\$ 2.1$ billion, primarily due to production of hybrid vehicles. This table is reproduced from Appendix A, Table A-33.

It is also interesting to note that the automotive industry has shown progress in reducing product development time. General Motors has reported lead times as low as sixteen months, compared to thirty-three months in 1998. In addition, materials costs have been reduced by $\$ 100$ million, which is reported to represent a forty percent $(40 \%)$ overall reduction in vehicle development cost. 
Exhibit 4-11: Capital Infrastructure Costs (Millions of 1999 Dollars)

\begin{tabular}{|c|c|c|c|c|c|c|c|c|}
\hline Year & $\begin{array}{c}\text { Advanced } \\
\text { Diesel }\end{array}$ & CNG & Electric & $\begin{array}{c}\text { Hybrid } \\
(2 X)\end{array}$ & $\begin{array}{l}\text { Hybrid } \\
(3 X)\end{array}$ & $\begin{array}{c}\text { Hydrogen } \\
\text { Fuel Cell }\end{array}$ & $\begin{array}{l}\text { Gasoline } \\
\text { Fuel Cell }\end{array}$ & Total \\
\hline 2005 & $\$ 24$ & $\$ 6$ & $\$ 0$ & $\$ 870$ & $\$ 0$ & $\$ 0$ & $\$ 0$ & $\$ 900$ \\
\hline 2006 & $\$ 184$ & $\$ 27$ & $\$ 0$ & $\$ 741$ & $\$ 0$ & $\$ 0$ & $\$ 0$ & $\$ 953$ \\
\hline 2007 & $\$ 323$ & $\$ 61$ & $\$ 0$ & $\$ 380$ & $\$ 5$ & $\$ 0$ & $\$ 0$ & $\$ 770$ \\
\hline 2008 & $\$ 162$ & $\$ 61$ & $\$ 5$ & $\$ 352$ & $\$ 44$ & $\$ 0$ & $\$ 0$ & $\$ 625$ \\
\hline 2009 & $\$ 144$ & $\$ 57$ & $\$ 41$ & $\$ 649$ & $\$ 181$ & $\$ 0$ & $\$ 3$ & $\$ 1,075$ \\
\hline 2010 & $\$ 94$ & $\$ 46$ & $\$ 95$ & $\$ 563$ & $\$ 326$ & $\$ 0$ & $\$ 166$ & $\$ 1,290$ \\
\hline 2011 & $\$ 113$ & $\$ 34$ & $\$ 89$ & $\$ 648$ & $\$ 307$ & $\$ 0$ & $\$ 905$ & $\$ 2,096$ \\
\hline 2012 & $\$ 30$ & $\$ 15$ & $\$ 77$ & $\$ 687$ & $\$ 186$ & $\$ 0$ & $\$ 777$ & $\$ 1,771$ \\
\hline 2013 & $\$ 17$ & $\$ 2$ & $\$ 133$ & $\$ 587$ & $\$ 107$ & $\$ 0$ & $\$ 138$ & $\$ 985$ \\
\hline 2014 & $\$ 0$ & $\$ 10$ & $\$ 134$ & $\$ 914$ & $\$ 75$ & $\$ 1$ & $\$ 71$ & $\$ 1,204$ \\
\hline 2015 & $\$ 0$ & $\$ 0$ & $\$ 167$ & $\$ 318$ & $\$ 60$ & $\$ 10$ & $\$ 359$ & $\$ 915$ \\
\hline 2016 & $\$ 0$ & $\$ 12$ & $\$ 63$ & $\$ 10$ & $\$ 216$ & $\$ 40$ & $\$ 0$ & $\$ 341$ \\
\hline 2017 & $\$ 0$ & $\$ 0$ & $\$ 21$ & $\$ 0$ & $\$ 877$ & $\$ 81$ & $\$ 0$ & $\$ 979$ \\
\hline 2018 & $\$ 0$ & $\$ 0$ & $\$ 2$ & $\$ 0$ & $\$ 910$ & $\$ 87$ & $\$ 0$ & $\$ 999$ \\
\hline 2019 & $\$ 0$ & $\$ 0$ & $\$ 0$ & $\$ 27$ & $\$ 615$ & $\$ 81$ & $\$ 0$ & $\$ 723$ \\
\hline 2020 & $\$ 0$ & $\$ 0$ & $\$ 0$ & $\$ 0$ & $\$ 515$ & $\$ 97$ & $\$ 0$ & $\$ 612$ \\
\hline 2021 & $\$ 0$ & $\$ 0$ & $\$ 111$ & $\$ 172$ & $\$ 787$ & $\$ 314$ & $\$ 0$ & $\$ 1,383$ \\
\hline 2022 & $\$ 0$ & $\$ 21$ & $\$ 105$ & $\$ 231$ & $\$ 664$ & $\$ 374$ & $\$ 0$ & $\$ 1,396$ \\
\hline 2023 & $\$ 0$ & $\$ 30$ & $\$ 87$ & $\$ 178$ & $\$ 475$ & $\$ 355$ & $\$ 0$ & $\$ 1,124$ \\
\hline 2024 & $\$ 0$ & $\$ 44$ & $\$ 142$ & $\$ 448$ & $\$ 670$ & $\$ 370$ & $\$ 0$ & $\$ 1,674$ \\
\hline 2025 & $\$ 0$ & $\$ 26$ & $\$ 77$ & $\$ 193$ & $\$ 351$ & $\$ 299$ & $\$ 0$ & $\$ 947$ \\
\hline 2026 & $\$ 0$ & $\$ 33$ & $\$ 98$ & $\$ 194$ & $\$ 233$ & $\$ 259$ & $\$ 0$ & $\$ 817$ \\
\hline 2027 & $\$ 0$ & $\$ 32$ & $\$ 94$ & $\$ 181$ & $\$ 227$ & $\$ 259$ & $\$ 0$ & $\$ 792$ \\
\hline 2028 & $\$ 0$ & $\$ 32$ & $\$ 93$ & $\$ 185$ & $\$ 208$ & $\$ 263$ & $\$ 0$ & $\$ 781$ \\
\hline 2029 & $\$ 0$ & $\$ 31$ & $\$ 92$ & $\$ 184$ & $\$ 208$ & $\$ 263$ & $\$ 0$ & $\$ 777$ \\
\hline 2030 & $\$ 23$ & $\$ 64$ & $\$ 201$ & $\$ 647$ & $\$ 576$ & $\$ 432$ & $\$ 0$ & $\$ 1,942$ \\
\hline
\end{tabular}

\section{Capital Constraints of Auto Manufacturers}

Exhibit 4-12 shows aggregate capital expenditures by the U.S. motor vehicle industry in billions of dollars for 1991 to 1997. The capital requirements analysis indicates that in most years, the capital spending on production facilities would be less than $\$ 2$ billion per year, which is substantially less than what the major domestic manufacturers have been spending on capital infrastructure. However, this may mean that other improvements may be deferred. 


\section{Exhibit 4-12: Aggregate Capital Expenditures}

(Billions of 1999\$)

\begin{tabular}{|c|c|c|c|c|}
\hline YEAR & GM & Ford & Chrysler & $\begin{array}{c}\text { Total } \\
\text { "Big 3" }\end{array}$ \\
\hline 1997 & $\$ 10.6$ & $\$ 8.3$ & $\$ 5.3$ & $\$ 24.2$ \\
\hline 1996 & $\$ 10.4$ & $\$ 8.6$ & $\$ 4.8$ & $\$ 23.8$ \\
\hline 1995 & $\$ 9.5$ & $\$ 9.3$ & $\$ 3.9$ & $\$ 22.7$ \\
\hline 1994 & $\$ 6.1$ & $\$ 9.1$ & $\$ 4.2$ & $\$ 19.4$ \\
\hline 1993 & $\$ 5.9$ & $\$ 7.6$ & $\$ 3.4$ & $\$ 16.8$ \\
\hline 1992 & $\$ 6.1$ & $\$ 6.6$ & $\$ 2.6$ & $\$ 15.3$ \\
\hline 1991 & $\$ 6.9$ & $\$ 6.8$ & $\$ 2.6$ & $\$ 16.4$ \\
\hline
\end{tabular}

\subsubsection{Costs of Various Pollutants}

The criteria pollutant emissions reduction values were calculated using an EPA estimate developed in 1990 which sets the costs of environmental controls at $\$ 380 /$ ton for CO, $\$ 3,840 /$ ton for $\mathrm{HC}$ and \$3,460/ton for $\mathrm{NO}_{\mathrm{x}}$ (Ref. 25). Costs in Reference 25 were modified to reflect 1999, dollars.

Various $\mathrm{CO}_{2}$ control cost estimates are indicated in Exhibit 4-13. Control costs are used instead of damage costs due to the great difficulty of calculating damage costs. These costs represent the "value" of reducing $\mathrm{CO}_{2}$ emissions.

For the QM 2003 evaluations, a low-end value of \$15/metric ton (tonne) of $\mathbf{C O}_{2}$ reduction was utilized. This equates to $\mathbf{\$ 5 5} / \mathbf{m e t r i c}$ ton of carbon reduced. Note that the QM benefit values (carbon reduction) relate to fuel economy/conservation effects only. 
Exhibit 4-13: Range of Costs to Control $\mathrm{CO}_{2}$ Emissions

\begin{tabular}{|c|c|c|c|c|c|}
\hline Study & Year & \multicolumn{2}{|c|}{$\begin{array}{l}\text { Reported Value } \\
\text { (\$/MMTCE) }\end{array}$} & $\begin{array}{l}\text { \$1996 Value } \\
\text { (\$/MMTCE) }\end{array}$ & Notes \\
\hline \multicolumn{6}{|c|}{ Costs of Tree Planting Used as a Reasonable First Approximation } \\
\hline Buchanan (Bonneville Power Adm.) & 1988 & $\begin{array}{l}\text { Low } \\
\text { High }\end{array}$ & $\begin{array}{l}\$ 17.08 \\
\$ 47.44\end{array}$ & $\begin{array}{l}\$ 22 \\
\$ 61\end{array}$ & \\
\hline Dudek and LeBlanc (EDF) & 1990 & $\begin{array}{l}\text { Low } \\
\text { High }\end{array}$ & $\begin{array}{l}\$ 53 \\
\$ 58\end{array}$ & $\begin{array}{l}\$ 63 \\
\$ 69\end{array}$ & \\
\hline Chernick and Caverhill & 1989 & $\begin{array}{l}\text { Low } \\
\text { High }\end{array}$ & $\begin{array}{c}\$ 80 \\
\$ 120\end{array}$ & $\begin{array}{l}\$ 99 \\
\$ 149\end{array}$ & \\
\hline \multicolumn{6}{|l|}{ Carbon Tax Required to Meet Stated Levels } \\
\hline EMF 12 (1990 levels) & 1992 & $\begin{array}{l}\text { Low } \\
\text { High }\end{array}$ & $\begin{array}{c}\$ 15 \\
\$ 150\end{array}$ & $\begin{array}{l}\$ 17 \\
\$ 165\end{array}$ & Summary of 10 models \\
\hline EMF 12 ( $10 \%$ below 1990 levels) & 1992 & $\begin{array}{l}\text { Low } \\
\text { High }\end{array}$ & $\begin{array}{l}\$ 35 \\
\$ 200 \\
\end{array}$ & $\begin{array}{r}\$ 39 \\
\$ 220 \\
\end{array}$ & Summary of 10 models \\
\hline EMF 12 (20\% below 1990 levels) & 1992 & $\begin{array}{l}\text { Low } \\
\text { High }\end{array}$ & $\begin{array}{l}\$ 50 \\
\$ 330\end{array}$ & $\begin{array}{l}\$ 55 \\
\$ 363\end{array}$ & Summary of 10 models \\
\hline AFL-CIO (1990 levels) & 1997 & & $\$ 100$ & $\$ 100$ & Congressional testimony \\
\hline David Montgomery (Charles R. Assoc.) & 1997 & $\begin{array}{l}\text { Low } \\
\text { High }\end{array}$ & $\begin{array}{l}\$ 150 \\
\$ 200\end{array}$ & $\begin{array}{l}\$ 150 \\
\$ 200\end{array}$ & Congressional testimony \\
\hline DOE/EIA (7\% below 1990 levels) & 1998 & & $\$ 348$ & $\$ 348$ & "Carbon price" for 2010 \\
\hline DOE/EIA (3\% below 1990 levels) & 1998 & & $\$ 294$ & $\$ 294$ & "Carbon price" for 2010 \\
\hline DOE/EIA (1990 levels) & 1998 & & $\$ 250$ & $\$ 250$ & "Carbon price" for 2010 \\
\hline DOE/EIA ( $9 \%$ over 1990 levels) & 1998 & & $\$ 163$ & $\$ 163$ & "Carbon price" for 2010 \\
\hline DOE/EIA ( $14 \%$ over 1990 levels) & 1998 & & $\$ 134$ & $\$ 134$ & "Carbon price" for 2010 \\
\hline DOE/EIA (24\% over 1990 levels) & 1998 & & $\$ 67$ & $\$ 67$ & "Carbon price" for 2010 \\
\hline \multicolumn{6}{|c|}{ Cost of Emission Allowances under a Trading System } \\
\hline Clinton Administration (domestic only) & 1998 & & $\$ 200$ & $\$ 196$ & The Oil Daily, 8/4/98 \\
\hline Clinton Administration (global trading) & 1998 & & $\$ 14$ & $\$ 13.72$ & The Oil Daily, 8/4/98 \\
\hline Cecil Roberts(UMWA) & $\begin{array}{l}1998 \\
1998\end{array}$ & & $\begin{array}{l}\$ 100 \\
\$ 200\end{array}$ & $\begin{array}{l}\$ 98 \\
\$ 196\end{array}$ & $\begin{array}{l}\text { Assumes global trading; Jl; etc. } \\
\text { No global trading }\end{array}$ \\
\hline \multicolumn{6}{|c|}{ Optimal Tax (taking into account projected damage) } \\
\hline Peck and Tiesberg & 1992 & & $\begin{array}{c}\$ 8 \\
\$ 210\end{array}$ & $\begin{array}{c}\$ 9 \\
\$ 231\end{array}$ & $\begin{array}{l}\text { Lower value is for } 1990 \\
\text { Higher value is for } 2200\end{array}$ \\
\hline Maddison & 1993 & & $\$ 16.84$ & $\$ 18$ & Tax for 2000 \\
\hline Nordhaus & 1993 & & $\$ 5.24$ & $\$ 6$ & \\
\hline Williams & 1995 & & $\$ 0$ & $\$ 0$ & \\
\hline \multicolumn{6}{|l|}{ Damage Estimates for Marginal Emissions } \\
\hline Fankhauser and Pearce & 1993 & $\begin{array}{l}\text { Low } \\
\text { High }\end{array}$ & $\begin{array}{c}\$ 5 \\
\$ 25\end{array}$ & $\begin{array}{l}\$ 5 \\
\$ 27\end{array}$ & \\
\hline Hope and Maul & 1996 & Low & $\begin{array}{l}\$ 5 \\
\$ 29\end{array}$ & $\begin{array}{l}\$ 5 \\
\$ 29 \\
\end{array}$ & $\begin{array}{l}\text { Mean value of initial scenario } \\
\text { Mean value for scenario } w / \text { highest cost }\end{array}$ \\
\hline Proposed Externality Values & & & & & \\
\hline California & 1990 & & $\$ 29$ & $\$ 35$ & Proposed value for resource planning \\
\hline Massachusetts & 1990 & & $\$ 92$ & $\$ 109$ & Proposed value for resource planning \\
\hline New York & 1990 & & $\$ 5$ & $\$ 6$ & Proposed value for resource planning \\
\hline Nevada & 1990 & & $\$ 61$ & $\$ 73$ & Proposed value for resource planning \\
\hline EPA (Renewable Electricity Generation) & 1992 & $\begin{array}{l}\text { Low } \\
\text { High }\end{array}$ & $\begin{array}{l}\$ 50 \\
\$ 150\end{array}$ & $\begin{array}{c}\$ 55 \\
\$ 165\end{array}$ & Values used for modelling purposes \\
\hline Miscellaneous & & & & & \\
\hline Ledbetter and Ross (ACEEE) & 1990 & & $\$ 176$ & $\$ 209$ & $\begin{array}{l}\text { Based on gas tax needed to raise CAFE } \\
\text { to } 44 \mathrm{mpg}\end{array}$ \\
\hline
\end{tabular}




\subsubsection{Aggregate Environmental Benefits Estimates}

Exhibit 4-14 lists the Carbon Coefficients for the different fuels. These coefficients are used in the Appendix A Table A-21, "Total Carbon Emissions Reductions" to calculate the reduction in carbon emissions each year to 2030 due to the market penetration of the advanced vehicle technologies.

\section{Exhibit 4-14: Carbon Coefficients}

\begin{tabular}{|l|c|}
\hline \multicolumn{1}{|c|}{ Fuel } & Coefficient, MMT/Quad $^{(1)}$ \\
\hline Gasoline (mkt. average) & 19.41 \\
\hline No. 2 Diesel Fuel & 19.95 \\
\hline CNG & 14.47 \\
\hline LPG & 17.16 \\
\hline Ethanol & 0.5823 \\
\hline Electric Utilities (mkt. average) & 22.32 \\
\hline
\end{tabular}

Source: DOE/EIA-0573, Emissions of Greenhouse Gases in the United States, Table 6, P. 15

(1) Million metric tons per quad ${ }^{15}$ BTU)

The OTT Program Analysis Methodology includes estimating reductions in carbon emissions from the commercialization of OTT-sponsored technologies. Exhibit 4-15 details carbon emission reductions estimated by technology. By 2030, the OTT program impact will reduce carbon emissions by more than twenty-four percent (24\%).

Emissions reductions for $\mathrm{NO}_{\mathrm{x}}, \mathrm{CO}$, and $\mathrm{HC}$ also are evaluated. Total emissions reductions and values for $\mathrm{NO}_{\mathrm{x}}, \mathrm{CO}$ and $\mathrm{HC}$ are found in Tables A24 - A29 in Appendix A. 
Exhibit 4-15: Carbon Emissions Reductions

\begin{tabular}{|c|c|c|c|c|}
\hline \multirow[t]{2}{*}{ Technology } & \multicolumn{4}{|c|}{$\begin{array}{c}\text { Carbon Reductions } \\
\text { Million Metric Tons Equivalent } \\
\text { (MMTCE) } \\
\end{array}$} \\
\hline & Year 2005 & Year 2010 & Year 2020 & Year 2030 \\
\hline Vehicle Technologies R\&D & 0.237 & 9.038 & 68.429 & 140.338 \\
\hline Hybrid Systems R\&D & 0.190 & 3.525 & 29.020 & 72.343 \\
\hline Fuel Cell R\&D & 0.000 & 0.044 & 7.160 & 21.557 \\
\hline Advanced Combustion R\&D & 0.026 & 3.694 & 14.742 & 16.415 \\
\hline Car CIDI & 0.018 & 2.387 & 8.382 & 8.644 \\
\hline Light Truck CIDI & 0.008 & 1.306 & 6.360 & 7.771 \\
\hline Electric Vehicle R\&D & 0.006 & 0.119 & 2.009 & 4.720 \\
\hline Household EV & 0.000 & 0.064 & 1.763 & 4.395 \\
\hline EPAct ZEV Mandates & 0.006 & 0.055 & 0.246 & 0.326 \\
\hline Heavy Vehicle Systems R\&D & 0.014 & 1.656 & 15.498 & 25.303 \\
\hline Class 3-6 & 0.000 & 0.052 & 0.677 & 1.647 \\
\hline Class 7\&8 & 0.014 & 1.605 & 14.821 & 23.655 \\
\hline Materials Technologies & 0.006 & 0.114 & 1.802 & 4.900 \\
\hline Propulsion System Materials & 0.000 & 0.000 & 0.000 & 0.000 \\
\hline Light Vehicle Materials & 0.006 & 0.114 & 1.802 & 4.900 \\
\hline Electric Vehicle & 0.000 & 0.006 & 0.170 & 0.424 \\
\hline Hybrid Vehicle & 0.006 & 0.103 & 0.845 & 2.107 \\
\hline $\begin{array}{l}\text { Fuel Cell Vehicle } \\
\end{array}$ & 0.000 & 0.005 & 0.787 & 2.369 \\
\hline Technology Deployment & 1.723 & 2.050 & 3.575 & 4.803 \\
\hline Household CNG & 0.003 & 0.377 & 1.838 & 2.987 \\
\hline EPAct Fleet & 1.720 & 1.673 & 1.737 & 1.816 \\
\hline Fuels Development & 0.318 & 3.185 & 18.269 & 54.809 \\
\hline Blends and Extenders & 0.245 & 2.918 & 17.874 & 30.124 \\
\hline Flex-Fuel & 0.073 & 0.267 & 0.395 & 24.685 \\
\hline Dedicated Conventional & 0.000 & 0.000 & 0.000 & 0.000 \\
\hline Fuel Cell & 0.000 & 0.000 & 0.000 & 0.000 \\
\hline Total & 2.284 & 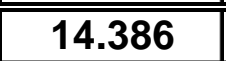 & 92.075 & 204.850 \\
\hline Baseline (AEO 01 - Transportation) & 573.1 & 628.5 & 730.8 & 849.8 \\
\hline Percent Reduction & $0.4 \%$ & $2.3 \%$ & $12.6 \%$ & $24.1 \%$ \\
\hline
\end{tabular}


Additional References used in Section 4-to be added to reference list at the end of the report.

16. "Two OEM Plants Open." Automotive Manufacturing, Volume 110, No. 1, SAE International, January 2002, p.16

17. Fitzgerald, Alison; "GM Says it Reduced Vehicle-Development Costs $40 \%$ in 5 Years", Bloomberg News (www.auto.com/industry/iwirf28_2001628.htm), June 28, 2001

\subsection{Accomplishments and Future Plans}

\subsection{Accomplishments}

Principal changes made in the Quality Metrics calculations compared to the preceding year are summarized below. These modifications contributed to the changes in oil savings and other program benefits:

1. As has been the practice with prior Quality Metrics analyses, the most current EIA AEO publication was used as the source for base case fuel. For the QM 2003 analyses, AEO 2001 was used.

2. A fuel cell vehicle technology using hydrogen was considered in the technology/fuel matrix. In the 2020 to 2030 period gasoline prices are projected to rise from AEO price projections through 2020 to reach $\$ 2.00 /$ gallon. The delivered cost of hydrogen was projected to decline during the same ten year period to $\$ 2.00 /$ gasoline gallon-equivalent.

3. In prior QM analyses, the SIDI technology was considered along with the CIDI. The SIDI has been dropped from consideration.

4. The Heavy Vehicle technologies were changed significantly from prior-year analyses. The current assumptions reflect the overall OTT Office of Heavy Vehicle Technologies program structure that considers all sources of energy consumption and loss of the vehicle.

5. New information sources describing industry investment levels for new body-styles and engines were identified and are included in the discussion of capital requirements.

\subsection{Future Plans}

Analytical improvements planned for future QM and OTT Impacts Assessments include the following:

- Modification of technologies and fuels considered, including consideration of changes in program emphasis in response to initiatives such as Freedom CAR, and/or findings resulting 
from the current study of the long-term future outlook for the North American transportation systems. This work, which is building on the Year 2050 study performed in 2000-2001, is being conducted jointly with Natural Resources Canada-and includes various modelling tasks addressing energy and transportation market issues.

- Completion of modifications to the Heavy Vehicle Market Penetration and related trucksector models, which were initiated as a result of considering a variety of energy conserving, and efficiency-improving technologies.

- More specific consideration of Class $2 b$ trucks in the energy use and market analysis.

- Assessment of the outlook between the present and 2010 for Diesel fuel formulations and price. The EPA rules to reduce diesel particulate emissions will affect refinery energy intensity, as well as overall vehicle efficiency. The target date for achieving the proposed emissions levels is 2007.

- Update of heavy vehicle emissions factors.

Additional assessment needs may be identified as a result of the periodic Analytic Review meetings held by the Office.

\subsection{References}

1. “Annual Energy Outlook 2001, With Projections to 2020," Energy Information Agency, Department of Energy, Washington, DC, Publication DOE/EIA-0383 (2001). (Website address: http://www.eia.doe.gov/bookshelf.html (Library/Archives-Forecasting).

2. Moore, J.S., et al., "Program Analysis Methodology: Office of Transportation Technologies, Quality Metrics 2002," U.S. Department of Energy, Office of Transportation Technologies, Washington, DC. (Web address: http://www.ott.doe.gov/analytical/impact_eval.html).

3. Thompkins, M., et al., "Determinants of Alternative Fuel Vehicle Choices in the Continental United States," $77^{\text {th }}$ Annual Meeting of the Transportation Research Board, Washington, D.C., January 1998.

4. "Assessment of the Costs and Benefits of Flexible and Alternative Fuel Use in the U.S. Transportation Sector: Technical Report Fourteen: Market Potential and Impacts of Alternative Fuel Use in Light-Duty Vehicles: A 2000/2010 Analysis," U.S. Department of Energy, DOE/PO-0042, January 1996.

5. 1997 Vehicle Inventory and Use Survey, EC97TV-US U.S. Bureau of the Census, Washington, DC, 1999.

6. 1997 Return on Investment Survey, American Trucking Association, Arlington, Va., 1997.

7. "Service Report: The Impacts of Increased Diesel Penetration in the Transportation Sector, EIA Office of Integrated Analyses and Forecasting," SR/OIAF/98-02, August 1998. (Web address: http://www.eia.gov/oiaf/servicerpt/preface.html).

8. Personal Communication with Stacy Davis, ORNL, November 2001. 
9. Mintz, M.M. and Saricks, "IMPACTT5A Model: Enhancements and Modifications since December 1994," Center for Transportation Research, Energy Systems Division, Argonne National Laboratory, Argonne, Illinois, September 1998.

10. Greene, D. \& Rathi, "Alternative Motor Fuel Use Model - Model Theory and Design, and Users' Guide,” ORNL/TM-11448, Oak Ridge, Tennessee, March 1990.

11. Personal Communication with Tien Nguyen, USDA Office of Fuels Development, October 2001

12. Greene, David L., "Survey Evidence on the Importance of Fuel Availability to Choice of Alternative Fuels and Vehicles," published with permission of the author, 1997.

13. Kline, D. (NREL), "Long-run Import Dependence and the Import Premium," Stanford University, Energy Modeling Forum 6, 1981. 
14. Hu, P.S. "Estimates of 1996 U.S. Military Expenditures on Defending Oil Supplies from the Middle East," Oak Ridge National Laboratory Technical Memorandum, Oak Ridge, Tennessee, January 1997.

15. "Two OEM Plants Open." Automotive Manufacturing, Volume 110, No. 1, SAE International, January 2002, p.16

16. Fitzgerald, Alison; "GM Says it Reduced Vehicle-Development Costs $40 \%$ in 5 Years", Bloomberg News (www.auto.com/industry/iwirf28_2001628.htm), June 28, 2001.

17. AAMA, “AAMA Motor Vehicles Facts \& Figures '96," American Automobile Manufacturers Association, Detroit, MI, 1997.

18. "Center Accelerates Ford R\&D: Product Teams' Goal--Cut Cycle to 36 Months," Automotive News, February 14, 1994, p.5.

19. “Ford's New World Car Worth \$6 Billion,” PRS Automotive Service, July 14, 1993.

20. "Ford to Refine Engine Plant," Automotive News, March 7, 1994.

21. Gwenell L. Bass, "Cost Scenarios of Shortening the Normal Product Lives of Cars," Congressional Research Service, May 29, 1992.

22. Girsky, S.J., et al., Automotive Industry--Industry Report Paine Webber Inc., April 10, 1995.

23. "GM is Expected to Put Saturn Complex in Tennessee as UAW Board Votes," Wall Street Journal, Eastern Edition, July 29, 1985, p.31.

24. Personal Communication from W. Schroeer, U.S. EPA, September 1990.

25. Davis, Stacy C., et al., Transportation Energy Data Book: Edition 21, Oak Ridge National Laboratory, Oak Ridge, Tennessee, September, 2001.

\subsection{Supporting Information}

\subsection{Glossary}

1. APU - Auxiliary Power Unit: APU's are smaller prime movers typically mounted within a vehicle to provide power to auxiliary equipment. An example would be to power a refrigeration system on a refrigerated truck. APU's are often more efficient than using the main power unit to provide power to auxiliary systems.

2. CIDI - Compression Ignition/Direct Injection: Diesel engines produce combustion via high pressure compression of the air/fuel mixture, rather than with a spark as in conventional automobile engines. Direct Injection (DI) diesel engines inject the fuel directly into the main combustion chamber rather 
than indirectly into a smaller pre-chamber. This tends to be more difficult to control, but yields a higher efficiency than the indirect injection technique. This term applies in this report to advanced direct-injected automotive-size diesel engines.

3. CNG: Compressed Natural Gas: When used as a transportation fuel, natural gas is stored on-board either as a compressed gas or a cryogenic liquid form. Most CNG systems store compressed natural gas at pressures up to 3,000 to 3,500 psig. At 3,000 psig, one gallon of compressed natural gas contains about 27,500 BTU, about $30 \%$ of the energy density of liquefied natural gas.

4. CV - Conventional Vehicle: In this case, this usually applies to a conventional automobile, powered with a spark ignition engine burning gasoline.

5. EE/RE - Office Energy Efficiency and Renewable Energy at DOE

6. EIA - Energy Information Agency

7. EPAct - Environmental Policy Act

8. ESM - Economic Spreadsheet Model

9. ETOH: An acronym abbreviation for ethanol or ethyl alcohol. Ethanol can be used in its "pure" form $(95 \%+$ ethanol) or as blended with various petroleum-based hydrocarbon fuels.

10. FCV-Fuel Cell (Powered) Vehicle: A vehicle obtaining motive power from an on-board fuel cell.

11. FFV - Flex Fuel Vehicle: A vehicle designed to operate within a range of different fuels or fuel mixtures. For instance, one vehicle may be designed to burn pure ethanol or mixtures if ethanol and gasoline within specific limits. Emissions effects often control the permitted ranges of FFV's.

12. FLEX FUEL-see FFV

13. FUEL ECONOMY - All fuel economy values presented in this report are normalized equivalent energy economy values, that is, miles per unit of energy consumed, where the unit of energy is defined as one gallon of standard-grade gasoline containing 125,000 BTU (high heat value). To convert to miles per million BTU, multiply values by 8.0.

14. GREET - Greenhouse Gases, Regulated Emissions, and Energy Use in Transportation Model

15. GPRA - Government Performance Results Act: The basis of the Quality Metrics Program.

16. GVW - Gross Vehicle Weight: This is the maximum total weight (vehicle + passengers + cargo) that is permitted by the manufacturers.

17. HEV - Hybrid Electric Vehicle: A Vehicle that utilizes two or more power systems for motive power-typically a combination internal combustion engine and a battery/motor. These systems may be interconnected in parallel (both providing motive power) or series (the internal combustion engine feeding the batteries and the batteries feeding the electric motor).

18. HDDV -Heavy Duty Diesel Vehicle: A generic term applied to large diesel-powered trucks.

19. HVMP - Heavy Vehicle Market Penetration Model

20. IMPACTT - Integrated Market Penetration and Anticipated Cost of Transportation Technologies Model

21. LV - Light Vehicle: An automobile or light truck under 6500 LB GVW.

22. LNG - Liquefied Natural Gas: Natural gas can be converted into liquid form for on-board storage if it is cooled to approximately $-258^{\circ} \mathrm{F}$. at atmospheric pressure.

23. LPG - Liquid Propane Gas: LP gas is typically a mixture of propane and butane. 
24. MMB/DOE-Millions of Barrels per day of Oil Equivalent: An energy measure expressed in cure oil production rate at 5.8 million BTU per barrel.

25. MMTONS - Million Metric Tons: Commonly used as a measure of carbon emissions generation.

26. NG - Natural Gas: A naturally-occurring mixture of light hydrocarbons (mostly methane with some ethane and higher carbon gases) as well as other trace gases (hydrogen, carbon dioxide, nitrogen). When gathered into pipelines, natural gas is made more uniform by mixing propane and other gases with it.

27. OAAT - Office of Advanced Automotive Technologies

28. OEM - Original Equipment Manufacturer

29. OFD - Office of Fuels Development

30. OTT - Office of Transportation Technologies in the DOE Office of Energy Efficiency and Renewable Energy

31. PNGV - Partnership for a New Generation Vehicle Program

32. QUADS: A measure of energy quantity. One Quad is equal to $10^{15}$ (a million-billion) BTU's. One Quad of petroleum is equal to 181 million barrels of crude petroleum or 8 billion gallons of gasoline. The US consumes about 100 Quads of energy annually.

33. RIMS II - Regional Input-Output Modeling System

34. RFG - Reformulated Gasoline: Gasoline that has been refined in such a way to reduce emissions more than conventional gasoline-typically lower in sulfur and with better control of the volatile subfraction.

35. SIDI - Spark ignition direct injection or stratified charge direct injection

36. VIUS - Vehicle Inventory and Use Survey

37. VMT - Vehicle Miles Traveled: This term usually applies to the sum of the miles traveled by each vehicle within a selected group. It is a measure of overall transportation service.

38. VSCC - Vehicle Size/Consumer Choice Model

39. ZEV - Zero Emissions Vehicle

\subsection{Energy Conversion Factors Used}

All energy values and conversion factors units used in this report are based on the values and conversion factors used in the Transportation Energy Data Book, Version 21 ORNL-6966 which

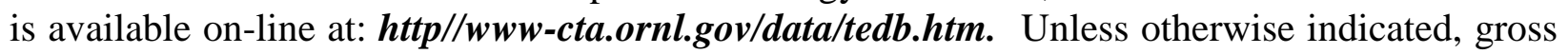
energy values (HHV) have been used throughout. 


\section{Appendix A: Quality Metrics 2003 Results Presentations}

Table 1. QM 2003 Summary Table - Energy savings, oil displaced, energy cost savings and carbon reductions for OTT Planning Units, 2000 - 2030 (3 pages)

Table 2. LDV Attributes - Ratio to Conventional

Table 3. GPRA: Advanced Vehicle Technologies, 2000 - 2030

Table 3a. GPRA: Advanced Automotive Technologies, 2000 - 2030

Table 3b. GPRA: Heavy Vehicle Technologies, 2000 - 2030

Table 3c. GPRA: Hybrid Systems R\&D, 2000 - 2030

Table 3d. GPRA: Fuel Cell R\&D, $2000-2030$

Table 3e. GPRA: Advance Combustion R\&D Automotive, 2000 - 2030

Table 3f. GPRA: Electric Vehicle R\&D, 2000 - 2030

Table 4. GPRA Materials Technologies, 2000 - 2030

Table 5. GPRA Technology Deployment, 2000 - 2030

Table 6. GPRA Fuels Development, 2000 - 2030

Table 7. OTT QM 2001 Planning Unit Estimates, 2000 - 2030

Table 8. The Transportation Petroleum Gap, 2000 - 2030

Table 9. Light Vehicle Market Penetration, 2000 - 2030

Table 10. Conventional and Advance Technology Market Penetration within Light Vehicle Size Class, $2000-2030$

Table 11. Conventional and Advance Technology Market Penetration in the Light Vehicle Sector - Total Stock, 2000 - 2030

Table 12. Annual New Light Vehicle Sales - numbers of vehicles sold, $2000-2030$

Table 13. Percent of Total Light Vehicles in Use, all technologies, 2000 - 2030

Table 14. Number of Light Vehicles in Use by year, all technologies, 2000 - 2030

Table 15. Summation of Gasoline Displaced by Light Vehicles, all technologies, $2000-2030$ (3 pages)

Table 16. Light Truck Class 1 \& 2 Advanced Diesel, all technologies, 2000 - 2030

Table 17. Projected Biofuels Demand - Ethanol, Blends and Extenders, 2000 - 2030

Table 18. EPACT Light Fleet Alternative Fuel Use Estimates - CNG, LPG, Ethanol, Methanol, 2000 - 2030

Table 19. ZEV and EPACT Light Electric Vehicle Fuel Use Estimates, 2000 - 2030

Table 20. Light Vehicle Energy Cost Savings, 2000 - 2030

Table 21. Transportation Energy Prices AEO '99, 2000 - 2030 
Table 22. Total Carbon Emission Reductions - all technologies, 2000 - 2030

Table 23. Value of Carbon Emission Reductions - all technologies, 2000 - 2030

Table 24. Light Vehicle $\mathrm{NO}_{\mathrm{x}}$ Emission Reductions - all technologies, 2000 - 2030

Table 25. Value of Light Vehicle NOx Emission Reductions - all technologies, 2000 - 2030

Table 26. Light Vehicle CO Emission Reductions - all technologies, 2000 - 2030

Table 27. Value of Light Vehicle CO Emission Reductions - all technologies, 2000 - 2030

Table 28. Light Vehicle HC Emission Reductions - all technologies, 2000 - 2030

Table 29. Value of Light Vehicle HC Emission Reductions - all technologies, 2000 - 2030

Table 30. Light Vehicle Purchase Price

Table 31. Total Consumer Investment - billion \$1999

Table 32. Total Incremental Consumer Investment - billion $\$ 1999$

Table 33. Incremental Capital Expenditures for Advanced Vehicle Production - million \$1999

Table 34. New Light Vehicle Fuel Economy

Table 35. Cost \& Efficiency Estimates for Heavy Vehicle Advanced Technologies

Table 36. Heavy Truck Advanced Technology Energy Savings \& Emissions Reduction Summary 


\title{
APPENDIX B: \\ Multipliers for Assessing the Economic Impacts \\ of Investment in Advanced Vehicle Transportation Technologies \\ Based on 1992 Industry Structure and 1995 Regional Data: \\ An Update
}

\author{
Jeffry M. Fang \\ National Renewable Energy Laboratory
}

October 7, 1998

Advanced vehicle transportation technologies involve bio-fuels, alternative fuels, electric and hybrid vehicles, fuel cells, heavy-duty vehicles, light-duty cars, trucks, and lightweight materials research and development. Investment in such technologies would lead to increases in vehicle costs, improved energy efficiency, and increased use of certain alternative fuels. In addition, there are fuel savings, and changes in consumer consumption expenditures. These changes have direct, indirect, and induced economic impacts on output and employment. In order to assess such impacts, output and employment multipliers are needed.

This note documents the multipliers to be used for making such assessments. It is an update of the September 4, 1998 version, entitled "Multipliers for Assessing the Economic Impacts of Investing in Advanced Transportation Technologies." It covers total output and employment multipliers and their composition, the changes from the 1987 industry structure to the 1992 structure, and some qualifications in the application of the multipliers presented. The appendices present information on the treatment of the bio-fuels industry, the equivalence of the three levels of industry details and aggregation, and the comparison of multipliers based on 1995 and 1992 data, with 1987 industry structure.

\section{Total Multipliers for Selected Industries}

Table 1 presents the total output and employment multipliers for the U.S. as a whole for those industries needed for computing the economic impacts of investment in research and development in advanced technologies in the automotive industry. These industries include motor vehicles, oil and gas extraction, electric utilities, gas utilities, households, and a sub-group of several industries that are to be used to approximate the production of bio-fuels such as ethanol and bio-diesel. The subgroup consists of farm products, wet corn milling, ${ }^{2}$ soybean oil mills, chemical preparations, n.e.c. ${ }^{3}$, soap and detergent, and petroleum refining.

${ }^{2}$ In the September 4, 1998 version of this note, the "forest products" industry (\#2 of 38) was used in place 


\section{Table 1: Final Demand Total Output and Employment Multipliers for Selected Industries}

\begin{tabular}{|c|c|c|c|c|}
\hline & & Final demar & Final demand & \\
\hline & & Multiplier: & Multiplier: & \\
\hline Code & Industry & $\begin{array}{l}\text { Output } \\
\qquad \$)\end{array}$ & $\begin{array}{l}\text { Employment } \\
\text { (Jobs/MM\$(1995)) }\end{array}$ & Comment \\
\hline [1] & [2] & [3] & [4] & [5] \\
\hline$\# 1$ of 38 & Farm products & 3.2411 & 48.6 & High \\
\hline$\# 14.1700$ & Wet corn milling ${ }^{*}$ & 2.7837 & 22.7 & Low \\
\hline$\# 14.2500$ & Soybean oil mills & 3.7692 & 35.8 & Medium \\
\hline \#27.0406 & $\begin{array}{l}\text { Chemical preparations, } \\
\text { n.e.c. }\end{array}$ & 3.0139 & 24.1 & High \\
\hline \#29.0201 & Soap \& detergent & 2.8060 & 19.2 & Medium \\
\hline \#31.0101 & Petroleum refining & 2.5168 & 11.7 & Low \\
\hline$\# 4$ of 38 & Oil \& gas extraction & 2.4222 & 16.0 & \\
\hline$\# 20$ of 38 & Motor vehicles & 3.3042 & 25.1 & \\
\hline \#68.0100 & Electric utilities & 2.3254 & 15.6 & \\
\hline \#68.0200 & Gas utilities $^{* *}$ & 2.9904 & 17.6 & \\
\hline$\# 38$ of 38 & Households & 2.1469 & 25.6 & \\
\hline Sources: & Bureau of Economic Ar & ysis, US Dep & Irtment of Commerce & \\
\hline & Regional Input-Output I & odeling Syste & (RIMS II) & \\
\hline & 1992 industry structure, & 995 regional & ata, U.S. total. & \\
\hline Notes: & $*$ This industry replaces & of 38, forest & products, in the $09 / 04$ / & 99 version. \\
\hline & ** Simple average of \#68 & 201 (natura & as transportation) and & \#68.0202 \\
\hline
\end{tabular}

These multipliers are derived from the Regional Input-Output Modeling System (RIMS II) developed by the Bureau of Economic Analysis (BEA), U.S. Department of Commerce. They are based on the 1992 industry structure for the U. S. as a whole and updated with 1995 regional data.

Columns 1 and 2 display the code and the name of the industry used by the BEA. Included are relevant industries from both the 490 detailed 6-digit industries and the 38industry aggregates. The former is represented by the code of the type \#xx.xxxx. The latter is shown with \#xx of 38.

of the "wet corn milling" industry. See Considerations of Bio-Fuels for more details.

${ }^{3}$ The abbreviation "n.e.c." stands for "not elsewhere classified." 
Column 3 shows the output multiplier, measuring the total dollar change in output in all industries that will result from a $\$ 1$ change in output delivered to final demand by the indicated industry. For example, for the motor vehicle industry (\#20 of 38), the output multiplier value for final demand is 3.3042, meaning that for each $\$ 1$ addition to final demand in the motor vehicle industry, the overall direct and indirect impacts on output is $\$ 3.3042$. Although the multipliers are derived in terms of 1995 dollars, there is no need to convert to 1995 dollars as long as the year-dollar designation is clearly displayed and kept in mind.

Column 4 presents the final demand employment multiplier. It measures the total change in the number of jobs in all industries that result from a $\$ 1$ million change in output delivered to the final demand by the indicated industry. Since these multipliers are computed using 1995 data, it is necessary, in applying the multipliers, to convert the estimated or forecast values of delivery to final demand from their expressed values to values with constant 1995 dollars.

Column 5 designates the employment impacts of a subgroup of six industries as high, medium, or low relative to those in the group. These six industries are intended to show the feedstock and the refining aspects of the process of manufacturing bio-fuels. Because industries used in RIMS II do not necessarily represent the actual process in bio-fuel production, there is some uncertainty as to the exact multipliers to apply. The refining process has elements similar to that of chemical preparations, n.e.c., soap and detergent, and petroleum refining. In addition, the feedstock may come from farm production, forestry production, and intermediate stage such as wet corn milling, or soybean oil milling. Because of the uncertainty associated with assigning the correct industry, the alternatives of low, medium, and high employment impacts can be used. To be "conservative" in estimating the employment impacts, one can combine the low feedstock impact with low refining impacts; i.e., combining "wet corn milling" with "petroleum refining." To be optimistic in terms of employment impacts, one could combine "farm products" with "chemical preparation, n.e.c." In the middle, one would combine "soybean oil mills" with "soap and detergent." The relative share of feedstock and refining process can be set at $35 \%$ and $65 \%$, based on the split in the cost of ethanol production. ${ }^{4}$

\section{Composition of Total Employment Multipliers}

Application of the total employment multipliers in Column 4 of Table 1 will yield only the total employment that will be generated by the delivery of $\$ 1$ million (in 1995 dollars) worth of final demand to the particular industry. To obtain the composition of the total employment generated, it is necessary to look into the component multipliers for each of the total employment multipliers included in Table 1. For this purpose, the 38- or 490- industry classifications mentioned above are too complicated and the resulting

\footnotetext{
${ }^{4}$ See Considerations of Bio-Fuels for additional discussion of bio-fuels.
} 
values for many industries are likely to have fairly small numbers. Fortunately, BEA also used a classification with the following 11 industry groups: ${ }^{5}$

$\begin{array}{ll}1 & \text { Farm, forestry, and fishery products } \\ 2 & \text { Mining } \\ 3 & \text { Construction } \\ 4 & \text { Durable goods } \\ 5 & \text { Non-durable goods } \\ 6 & \text { Transportation and public utilities } \\ 7 & \text { Wholesale trade } \\ 8 & \text { Retail trade } \\ 9 & \text { Finance, insurance, and real estate } \\ 10 & \text { Service } \\ 11 & \text { Private households }\end{array}$

In such a scheme, these 11 industry groups cover the entire domestic economy. Table 2 presents the component employment multipliers with such industry groupings. Columns 1 and 2 show the numerical designation and names of industry aggregation. Columns 3 through 13 present the detailed component multipliers for those industries included in Table 1. The column headings correspond to those industries shown in Table 1. For example, Column 3 is for the "farm products" sector in the 38-industry classification (\#1 of 38). Similarly, Col. 8 is for the petroleum refining industry (\#31.0101), one of the 490 detailed component industries.

Each entry in Table 2 represents the additional number of jobs that will occur as a result of \$1 million (in 1995 constant dollars) in final demand delivered to the column industry. The "total" row is a simple sum of the 11 industry groups. The values in this row, when rounded, correspond to the total employment multipliers in Table 1.

Similar to the application of total employment multipliers in Table 1, it is necessary to convert "the final demand delivered" to millions of 1995 dollars when applying the multiplier values in Table 2 .

\section{Composition of the Total Output Multipliers}

Table 3 presents the component output multipliers for the total output multipliers shown in Table 1. The format is essentially the same as Table 2 for total employment multipliers except for the total row. In Table 3, the total row represents the sum of only the first 10 industry groups, excluding the "private households" sector. According to the BEA, private households contribute to aggregate output through their earnings. To

\footnotetext{
${ }^{5}$ For the correspondence among the 11-industry groups, the-38 industry classifications, and the detailed 490 component industries, see Correspondence Among the Three Levels of Industry Aggregation In the RIMS II Model.
} 
Table 2: Composition of Total Employment Multipliers for Selected Industries 1992 Industry Structure, 1995 Regional Data, US Total

\begin{tabular}{|c|c|c|c|c|c|c|c|c|c|c|c|c|}
\hline NDIA* & Industry Aggregation & $\# 1$ of $38 * *$ & $\# 14.1700$ & $\# 14.2500$ & \#27.0406 & $\begin{array}{r}\# 29.020 \\
1\end{array}$ & \#31.0101 & $\# 4$ of 38 & \#20 of 38 & \#68.0100 & \#68.0200 & \#38 of 38 \\
\hline [1] & {$[2]$} & {$[3]$} & {$[4]$} & {$[5]$} & {$[6]$} & [7] & {$[8]$} & [9] & {$[10]$} & {$[11]$} & {$[12]$} & {$[13]$} \\
\hline 1 & Farm, forestry, and fishery products*^ & 29.7902 & 7.8398 & 14.4261 & 1.4283 & 0.6962 & 0.3147 & 0.4139 & 0.6746 & 0.4324 & 0.4567 & 1.1796 \\
\hline 2 & Mining & 0.1591 & 0.1973 & 0.1488 & 0.4173 & 0.1679 & 1.4029 & 4.2481 & 0.1564 & 0.6621 & 1.8334 & 0.1142 \\
\hline 3 & Construction & 0.6967 & 0.6271 & 0.6834 & 0.5485 & 0.4868 & 0.6788 & 0.7978 & 0.5435 & 1.3534 & 1.9089 & 0.5763 \\
\hline 4 & Durable goods & 0.8019 & 0.5425 & 0.7473 & 0.7480 & 0.6404 & 0.4204 & 0.5879 & 5.8802 & 0.6322 & 0.6769 & 0.8235 \\
\hline 5 & Non-durable goods & 1.8274 & 2.2816 & 3.4873 & 6.0292 & 4.8421 & 1.2637 & 0.6499 & 2.0586 & 0.7084 & 0.7460 & 1.6604 \\
\hline 6 & Transportation and public utilities & 1.4635 & 1.4453 & 1.6208 & 2.2196 & 1.3503 & 0.8760 & 0.8073 & 1.4925 & 3.3888 & 2.3319 & 1.2781 \\
\hline 7 & Wholesale trade & 1.6201 & 1.3269 & 2.4486 & 1.2870 & 1.3462 & 0.7872 & 0.5091 & 1.8070 & 0.5536 & 0.6720 & 1.0128 \\
\hline 8 & Retail trade & 2.2497 & 1.4897 & 2.1202 & 2.1375 & 1.8204 & 1.0468 & 1.2884 & 2.5029 & 1.4344 & 1.5539 & 4.0532 \\
\hline 9 & Finance, insurance, $\&$ real estate & 2.0166 & 1.5120 & 2.5733 & 1.6607 & 1.4003 & 0.8865 & 1.7456 & 1.6034 & 1.2450 & 1.3050 & 2.6464 \\
\hline 10 & Service & 7.7636 & 5.3597 & 7.3810 & 7.4513 & 6.3676 & 3.9166 & 4.8437 & 8.1898 & 5.1198 & 5.9948 & 11.9048 \\
\hline 11 & Private households & 0.1757 & 0.1069 & 0.1596 & 0.1588 & 0.1310 & 0.0758 & 0.0966 & 0.1571 & 0.1071 & 0.1123 & 0.3353 \\
\hline & Total & 48.5645 & 22.7288 & 35.7964 & 24.0862 & 19.2492 & 11.6694 & 15.9883 & 25.066 & 15.6372 & 17.5916 & 25.5846 \\
\hline
\end{tabular}

Source: Bureau of Economic Analysis, U.S. Department of Commerce, RIMS II, 1992 industry structure, 1995 regional data, US total.

Notes:

* NDIA - Numerical designation of industry aggregation.

** The column industries are:

\#1 of 38 Farm products \#4 of 38 Oil \& gas extraction

$\# 14.1700 \quad$ Wet corn milling \#20 of 38 Motor vehicles

\#14.2500 Soybean oil mills \#68.0100 Electric utilities

\#27.0406 Chemical preparations, n.e.c. \#68.0200 Gas utilities (Simple average of \#68.0201 (gas transportation) and \#68.0202 (gas distribution))

\#29.0201 Soap \& detergent \#38 of 38 Households

\#31.0101 Petroleum refining

*^ Each entry in this table indicates the number of jobs that will be generated in the row industry for every $\$ 1$ million in 1995 dollars delivered to column industry. 
Table 3: Composition of Total Output Multipliers for Selected Industries 1992 Industry Structure, 1995 Regional Data, US Total

\begin{tabular}{|c|c|c|c|c|c|c|c|c|c|c|c|c|}
\hline $\begin{array}{l}\text { NDIA* } \\
{[1]}\end{array}$ & $\begin{array}{c}\text { Industry Aggregation } \\
\text { [2] }\end{array}$ & $\begin{array}{c}\# 1 \text { of } 38 * * \\
{[3]}\end{array}$ & $\begin{array}{c}\# 14.1700 \\
{[4]}\end{array}$ & $\begin{array}{c}\# 14.2500 \\
{[5]}\end{array}$ & $\begin{array}{c}\# 27.0406 \\
{[6]}\end{array}$ & $\begin{array}{c}\# 29.0201 \\
{[7]}\end{array}$ & $\begin{array}{c}\# 31.0101 \\
{[8]}\end{array}$ & $\begin{array}{r}\# 4 \text { of } 38 \\
{[9]}\end{array}$ & $\begin{array}{c}\# 20 \text { of } 38 \\
{[10]}\end{array}$ & $\begin{array}{c}\# 68.0100 \\
{[11]}\end{array}$ & $\begin{array}{c}\# 68.0200 \\
{[12]}\end{array}$ & $\begin{array}{c}\# 38 \text { of } 38 \\
{[13]}\end{array}$ \\
\hline 1 & Farm, forestry, and fishery products*^ & 1.3530 & 0.4025 & 0.7980 & 0.0655 & 0.0338 & 0.0148 & 0.0192 & 0.0316 & 0.0202 & 0.0214 & 0.0546 \\
\hline 2 & Mining & 0.0398 & 0.0496 & 0.0379 & 0.0864 & 0.0428 & 0.4040 & 1.2272 & 0.0364 & 0.1582 & 0.5278 & 0.0293 \\
\hline 3 & Construction & 0.0491 & 0.0460 & 0.0507 & 0.0403 & 0.0358 & 0.0445 & 0.0562 & 0.0383 & 0.0985 & 0.1328 & 0.0406 \\
\hline 4 & Durable goods & 0.1263 & 0.0836 & 0.1163 & 0.1270 & 0.1023 & 0.0653 & 0.0956 & 1.6353 & 0.0959 & 0.1047 & 0.137 \\
\hline 5 & Non-durable goods & 0.4197 & 1.2411 & 1.4024 & 1.4979 & 1.5967 & 1.1798 & 0.1386 & 0.3552 & 0.1479 & 0.1564 & 0.3263 \\
\hline 6 & Transportation and public utilities & 0.2150 & 0.2320 & 0.2397 & 0.2952 & 0.1984 & 0.2554 & 0.1528 & 0.2140 & 1.1962 & 1.2934 & 0.2077 \\
\hline 7 & Wholesale trade & 0.1661 & 0.1361 & 0.2511 & 0.1320 & 0.1381 & 0.0807 & 0.0522 & 0.1853 & 0.0568 & 0.0690 & 0.1039 \\
\hline 8 & Retail trade & 0.0950 & 0.0629 & 0.0895 & 0.0902 & 0.0768 & 0.0442 & 0.0544 & 0.1056 & 0.0605 & 0.0656 & 0.1711 \\
\hline 9 & Finance, insurance, \& real estate & 0.3670 & 0.2339 & 0.3841 & 0.2716 & 0.2309 & 0.2100 & 0.3692 & 0.2721 & 0.2085 & 0.2863 & 0.4557 \\
\hline 10 & Service & 0.4102 & 0.2959 & 0.3993 & 0.4076 & 0.3505 & 0.2182 & 0.2568 & 0.4304 & 0.2825 & 0.3330 & 0.6208 \\
\hline 11 & Private households & 0.8422 & 0.5125 & 0.7652 & 0.7615 & 0.6278 & 0.3633 & 0.4629 & 0.7531 & 0.5136 & 0.5381 & 1.6075 \\
\hline & Total $^{\wedge \wedge}$ & 3.2412 & 2.7836 & 3.7690 & 3.0137 & 2.8061 & 2.5169 & 2.4222 & 3.3042 & 2.3252 & 2.9902 & 2.1470 \\
\hline
\end{tabular}

Source: Bureau of Economic Analysis, U.S. Department of Commerce, RIMS II, 1992 industry structure, 1995 regional data, US total.

Notes:

* NDIA - Numerical designation of industry aggregation.

** The column industries are:

\#1 of 38 Farm products \#4 of $38 \quad$ Oil \& gas extraction

\#14.1700 Wet corning milling \#20 of 38 Motor vehicles

\#14.2500 Soybean oil mills $\quad$ \#68.0100 Electric utilities

\#27.0406 Chemical preparations, n.e.c. \#68.0200 Gas utilities (Simple average of natural gas transportation (\#68.02010) and natural gas distribution (\#68.0202)).

\#29.0201 Soap \& detergent \#38 of 38 Households

\#31.0101 Petroleum refining

*^ Each entry in this table indicates the additional output that will be generated in the row industry for every $\$ 1$ of final demand delivered to column industry.

$\wedge \wedge$ The "Total" row includes only NDIA 1 through 10. The contributions of private households to aggregate output are represented by their earnings.

To avoid double counting, they are not included in the total output multipliers. 
include such earnings in the total output multiplier again would represent a double counting.

Note that the values in the "total" row in Table 3 are nearly identical to those of Column 4 of Table 1 . The only differences are due to rounding. Each entry in Table 3 represents the dollar change in output that occurs in the row industry for each additional dollar of output delivered to the final demand by the column industry. The multipliers are, in a sense, absolute values and can be applied directly as long as the same year-dollar combination is used.

\section{Converting to 1995 Constant Dollars}

Given that the employment multipliers in Tables 1 and 2 are derived using constant 1995 dollars, the projected output values need to be converted into 1995 dollars before the multipliers can be applied. Table 4 presents the latest data on implicit GDP price deflators from 1992 through 1997, which can be used for this purpose. For example, if the projected output is in terms of 1997 constant dollars, they need to be deflated by 1.0378 .

Table 4. Implicit Gross Domestic Products Price Deflators, 1992-1997

\begin{tabular}{|c|c|c|}
\hline Year & $1992=100$ & $1995=100$ \\
\hline 1992 & 100.00 & 93.01 \\
\hline 1993 & 102.64 & 95.47 \\
\hline 1994 & 105.09 & 98.50 \\
\hline 1995 & 107.51 & 100.00 \\
\hline 1996 & 109.53 & 101.88 \\
\hline 1997 & 111.57 & 103.78 \\
\hline
\end{tabular}

Source: Bureau of Economic Analysis, Department of Commerce, Survey of Current Business, August 1998, Table 3, p. 159.

\section{Changes from the 1987 Industry Structure, 1995 Regional Data Version}

The current version of RIMS II model is based on 1992 industry structure and 1995 regional data. Several changes from the model using 1987 structure and 1995 data can be noted. First, in conjunction with the switch from 1987 industry structure to 1992 structure, the BEA now uses the standard industrial classification (SIC), rather than the input-output classification of industries. Thus, the number of detailed component industries increases from 471 to 490 . For example, the number of industries in the construction sector increases from 5 to 15 . The natural gas utility industry is the one industry covered in this note affected by such change. Instead of just one industry for natural gas (\#68.0200), it is now composed of two industries, natural gas transportation (\#68.0201) and natural gas distribution (\#68.0202). However, for our purpose, they are 
re-combined by using the simple average. Second, the shift of industry structure from the 1987 benchmark to the 1992 benchmark caused a change in the industry used to represent the low employment impacts at the input stage of the bio-fuels production process. "Wet corn milling" (\#14.1700) now replaces "forest product" (\#2 of 38) as the industry with low employment impact. ${ }^{6}$ Third, the magnitude of change in the numeric values of multipliers varies substantially among the industries considered in this note. In terms of total employment multipliers, "wet corning milling" (\#14.1700) showed a large decrease (about 27\%), while oil \& gas extraction and gas utilities increased by approximately $33 \%$ and $29 \%$, respectively (Table 5, Column 5). In contrast, the differences in employment multiplier values for other industries such as forest products, soybean oil mills, and household are relatively small. Further, the pattern of changes in the values of output multipliers is similar to that of the employment multipliers (Compare Col. (8) and Col. (5) of Table 5.)

\section{Qualifications}

When applying the output and employment multipliers to assess the future output and employment impacts from investment in advanced transportation technologies, it is explicitly assumed that the observed past relationship will continue in the future. This assumption derives from the static nature of the input-output analysis, which takes a snap shot of the economy as a whole at a given point of time. However, as can be seen from the comparison between the multipliers from the 1987 structure to the 1992 structure in the previous section, the industry structure does change over time, affecting the values of the multipliers to be applied. Nevertheless, it is still useful to hold the industry structure constant and assess the likely impacts of investing in advanced vehicle transportation technologies.

The multipliers presented in this note are for the total U.S. They should not be used for individual state, economic region, or county. Since the U.S. as a whole represents a much larger enclosed economy than each sub-region, the "leakage" from the system is proportionally much smaller than that of each sub-region. As a result, the US total multipliers are larger than those associated with individual regions. If the focus is on the economic impacts in a specific state or region, multipliers developed specifically for the state or region should be used.

\footnotetext{
6 See Considerations of Bio-Fuels.
} 
References

Bureau of Economic Analysis, Department of Commerce, “ RIMS II Multipliers, 1992 Benchmark, 1995 Regional Data, US Total.” September 16, 1998

Bureau of Economic Analysis, Department of Commerce, " GDP and Other Major NIPA Series, 1929-97.” Survey of Current Business, August 1998. Pp. 147-166

Bureau of Economic Analysis, Department of Commerce, “ RIMS II Multipliers, 1987 Benchmark, 1995 Regional Data, US Total.” June 22, 1998

Bureau of Economic Analysis, Department of Commerce, Regional Multipliers: A User Handbook for the Regional Input-Output Modeling System (RIMS II), third edition. March 1997

Bureau of Economic Analysis, Department of Commerce, “ RIMS II Multipliers, 1987 Benchmark, 1992 Regional Data, US Total.” October 31, 1996 
Table 5: Comparisons of Employment and Output Multipliers Based on 1987 and 1992 Industry structures (1995 Regional Data)

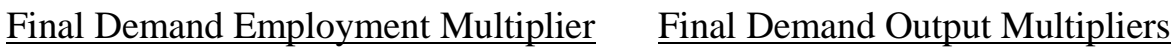

\begin{tabular}{|c|c|c|c|c|}
\hline 1987 & 1992 & & 1987 & 1992 \\
\hline $\begin{array}{l}\text { Structure } \\
\text { bs/MM95\$ }\end{array}$ & $\begin{array}{c}\text { Structure } \\
\text { Jobs/MM95\$ }\end{array}$ & {$[4] /[3]$} & $\begin{array}{c}\text { Structure } \\
\$\end{array}$ & $\begin{array}{c}\text { Structure } \\
\$\end{array}$ \\
\hline
\end{tabular}

\begin{tabular}{|c|c|c|c|c|c|c|c|}
\hline Code & Industry & $\begin{array}{c}\text { Structure } \\
\text { Jobs/MM95\$ }\end{array}$ & $\begin{array}{c}\text { Structure } \\
\text { Jobs/MM95\$ }\end{array}$ & {$[4] /[3]$} & $\begin{array}{c}\text { Structure } \\
\$\end{array}$ & $\begin{array}{c}\text { Structure } \\
\$\end{array}$ & {$[/] /[6]$} \\
\hline$[1]$ & {$[2]$} & {$[3]$} & {$[4]$} & {$[5]$} & {$[6]$} & [7] & [8] \\
\hline \#1 of 38 & Farm products & 52.0 & 48.6 & 0.935 & 3.4530 & 3.2411 & 0.939 \\
\hline \#2 of 38 & Forest products & 28.4 & 28.3 & 0.996 & 2.8553 & 2.8317 & 0.992 \\
\hline \#14.1700 & Wet corn milling & 31 & 22.7 & 0.732 & 3.4637 & 2.7837 & 0.804 \\
\hline$\# 14.2500$ & Soybean oil mills & 35.5 & 35.8 & 1.008 & 3.7935 & 3.7692 & 0.994 \\
\hline \#27.0406 & Chemical preparations, n.e.c. & 21.6 & 24.1 & 1.116 & 2.9132 & 3.0139 & 1.035 \\
\hline \#29.0201 & Soap \& detergent & 17.3 & 19.2 & 1.110 & 2.7296 & 2.8060 & 1.028 \\
\hline \#31.0101 & Petroleum refining & 10.4 & 11.7 & 1.125 & 2.3475 & 2.5168 & 1.072 \\
\hline \#4 of 38 & Oil \& gas extraction & 12.0 & 16.0 & 1.333 & 1.9443 & 2.4222 & 1.246 \\
\hline$\# 20$ of 38 & Motor vehicles & 24.0 & 25.1 & 1.046 & 3.2388 & 3.3042 & 1.020 \\
\hline \#68.0100 & Electric utilities & 14.4 & 15.6 & 1.083 & 2.2404 & 2.3254 & 1.038 \\
\hline \#68.0200 & Gas utilities & 13.6 & 17.6 & 1.294 & 2.6559 & 2.9904 & 1.126 \\
\hline \#38 of 38 & Households & 25.9 & 25.6 & 0.988 & 2.1796 & 2.1469 & 0.985 \\
\hline
\end{tabular}




\section{Considerations of Bio-Fuels}

Bio-fuels include mainly bio-ethanol and bio-diesel. The feedstock for producing ethanol may come from corn, switch grass, short rotation woody crops, and agricultural waste such as corn stover, or municipal waste. On the input side, the raw materials come from the farm and the forestry industries. The treatment and refining processes have elements which are somewhat similar to that of petroleum refining, wet corn milling, the milling of cottonseed oil, soybean oil, and vegetable oils, or the process of producing soap and detergents, and some other chemical preparations. In this appendix, the approach to assign multipliers for approximating the production of bio-fuels is explained, using the industry structure for both 1992 and 1987, and 1995 regional data.

\section{Industry Structure, 1995 Data}

The RIMS II bio-fuel related industries and their associated multipliers are shown in Table A1. These industries are segregated into two groups. The first group includes the first six, from farm products to vegetable oil mills. These industries can be viewed as the input or feedstock side of process. Looking at the employment multiplier, the high value is the farm products industry with 48.6. The low value is the wet corn milling industry with 22.7. In the middle is the soybean oil mills industry with 35.8. These are labeled with "high," "low," and "medium" respectively. The second group includes chemical preparations, n. e. c., soap \& detergent, and petroleum refining. They refer to the refining part of the bio-fuel production process. They are also assigned high, medium, and low ratings based on the magnitude of the employment multiplier.

Table A1. Output and Employment Multipliers for Industries for Bio-fuels (1992 Industry Structure, 1995 Regional Data, U.S.)

\begin{tabular}{|c|l|c|c|l|}
\hline $\begin{array}{c}\text { Industry } \\
\text { Code }\end{array}$ & \multicolumn{1}{|c|}{ Industry } & $\begin{array}{c}\text { Output } \\
\text { Multiplier }\end{array}$ & $\begin{array}{l}\text { Employment } \\
\text { Multiplier }\end{array}$ & Note \\
\hline$\# 1$ of 38 & Farm products & 3.2411 & 48.6 & High \\
\hline$\# 2$ of 38 & Forest products & 2.8311 & 28.3 & \\
\hline 14.1700 & Wet corn milling & 2.7837 & 22.7 & Low \\
\hline 14.2400 & $\begin{array}{l}\text { Cottonseed oil } \\
\text { mills }\end{array}$ & 3.6317 & 39.4 & \\
\hline 14.2500 & Soybean oil mills & 3.7692 & 35.8 & Medium \\
\hline 14.2600 & Vegetable oil mills & 3.6966 & 38.4 & \\
\hline 27.0406 & $\begin{array}{l}\text { Chemical } \\
\text { preparations, n.e.c. }\end{array}$ & 3.0139 & 24.1 & High \\
\hline 29.0201 & Soap \& detergent & 2.8060 & 19.2 & Medium \\
\hline 31.0101 & Petroleum refining & 2.5165 & 11.7 & Low \\
\hline
\end{tabular}

Since it is not clear which industry grouping in RIMS II correspond most closely to the bio-fuels industry in terms of their economic impacts, it is necessary to approximate it by 
combining the two stages of production process. To be conservative on the employment impact, the wet corn milling industry can be combined with petroleum refining. On the optimistic side, the farm products industry can be combined with chemical preparation, n.e.c. On the average side, soybean oil mills is paired with soap and detergent industry.

\section{Industry Structure, 1995 Data}

Table A2 presents the same type of information as Table A1, except that it is based on 1987 industry structure. The change in the underlying industry structure yielded one major change. The low employment impact industry on the feedstock side now is forest products (\#2 of 38), instead of wet corn milling.

Table A2. Output and Employment Multipliers for Industries for Bio-fuels (1987 Industry Structure, 1995 Data)

\begin{tabular}{|c|l|c|c|l|}
\hline $\begin{array}{c}\text { Industry } \\
\text { Code }\end{array}$ & \multicolumn{1}{|c|}{ Industry } & $\begin{array}{c}\text { Output } \\
\text { Multiplier }\end{array}$ & $\begin{array}{l}\text { Employment } \\
\text { Multiplier }\end{array}$ & Note \\
\hline$\# 1$ of 38 & Farm products & 3.4530 & 52.0 & High \\
\hline$\# 2$ of 38 & Forest products & 2.8553 & 28.4 & Low \\
\hline 14.1700 & Wet corn milling & 3.4637 & 31.0 & \\
\hline 14.2400 & $\begin{array}{l}\text { Cottonseed oil } \\
\text { mills }\end{array}$ & 3.9528 & 45.9 & \\
\hline 14.2500 & Soybean oil mills & 3.7935 & 35.5 & Medium \\
\hline 14.2600 & Vegetable oil mills & 3.6073 & 36.8 & \\
\hline 27.0406 & $\begin{array}{l}\text { Chemical } \\
\text { preparations, n.e.c. }\end{array}$ & 2.9132 & 21.6 & High \\
\hline 29.0201 & Soap \& detergent & 2.7296 & 17.3 & Medium \\
\hline 31.0101 & Petroleum refining & 2.3475 & 10.4 & Low \\
\hline & & & & \\
\hline
\end{tabular}

\section{Allocation Factor}

What is the division between the feedstock side and the refining side of the bio-fuels production process? Since feedstock is approximately $35 \%$ of the cost of ethanol production, a $35 \%$ and $65 \%$ division is used for this purpose. In application, it is recommended that that these relative shares be applied to the total value of production first to derive the respective production values due to feedstock and due to the refining process. These separate production values are then multiplied with their respective multipliers to generate the output and employment impacts at each stage. They are then summed to derive total output and employment impacts. 


\section{Correspondence Among the Three Levels of Industry Aggregation In the RIMS II Model}

\begin{tabular}{|l|l|l|l|}
\hline $\begin{array}{l}\text { Numerical } \\
\text { designation } \\
\text { of industry } \\
\text { aggregation }\end{array}$ & Industry Aggregation & $\begin{array}{l}\text { Numerical } \\
\text { designation of } \\
\text { component detailed } \\
\text { industries }\end{array}$ & $\begin{array}{l}\text { Numerical } \\
\text { designation of } \\
\text { component 38 } \\
\text { Industry } \\
\text { aggregations }\end{array}$ \\
\hline 1 & Farm \& forestry products & $1.0100-4.0002$ & $1-2$ \\
\hline 2 & Mining & $5.000-10.000$ & $3-5$ \\
\hline 3 & Construction & $11.0101-12.0300$ & 6 \\
\hline 4 & Durable goods & $13.0100-13.0700$, & $14-23$ \\
& & $20.0100-23.0700$, & \\
\hline 5 & Non-durable goods & $\begin{array}{l}14.0100-64.1200 \\
24.0100-19.0306\end{array}$ & $7-13$ \\
\hline 6 & Transportation \& Public & $65.0100-68.0305$ & $24-26$ \\
\hline 7 & Utilities & $78.0100-78.0200$ & \\
\hline 8 & Wholesale trade & 69.0100 & 27 \\
\hline 9 & Retail trade & 69.0200 & 28 \\
\hline 10 & Finance, insurance, \& real & $70.0100-71.0202$ & $29-31$ \\
\hline 11 & Sertate & $72.0101-77.0900$ & $32-37$ \\
\hline
\end{tabular}




\section{Comparison of Multipliers Based on 1992 and 1995 Data, 1987 Industry Structure}

In the main text of this note, RIMS II employment and output multipliers based on 1992 industry structure and 1995 data were presented and compared with those based on 1987 structure and 1995 data. An earlier version of BEA's RIMS II results was based on1987 industry structure and 1992 data. Thus, it is also possible to compare the two sets of multipliers to see if they change to any extent when data from different years are applied to the same industry structure. Tables $\mathrm{C} 1$ and $\mathrm{C} 2$ present such comparison, respectively, for the output multipliers and for the employment multipliers.

- In general, the changes are fairly minor for the output multipliers. For those industries included in this analysis, the difference is less than 1\% (Table $\mathrm{C} 1$ ).

- For the employment multipliers, the changes are largest for sectors such as farm products $(19 \%)$, soybean oil mills $(14 \%)$, and forest products $(7 \%)$. Otherwise the difference are less than 3\% (See Table C2).

- The apparent reason for such differences is that there were much larger changes in the earnings/employment ratio in the farm products, forest products, and soybean oil mills industries than in the other industries. Computations show that from 1992 to 1995 , the ratio of earnings/employment decreased by $16 \%$ for the farm products industry, by $12 \%$ for the soybean oil mills industry, and by $6 \%$ for the forest products industry. In contrast, the other industries covered in this note have changes that are within + or $-3 \%$.

In this comparison, the forest products industry (\#2 of 38) is used, instead of the wet corn milling industry (\#14.1700) that is used in the main text. As explained in Appendix A, when multipliers from the 1987 structure with 1995 data are considered, the forest products industry is the one with the lowest employment impacts in the input side of the bio-fuel production process. 
Table C1: Comparisons of Output Multipliers

Based on 1992 and 1995 Data, and 1987 Industry Structure

Final Demand Output Multiplier

Code

[1]

\#1 of 38 Farm products

\#2 of 38 Forest products

\#14.2500 Soybean oil mills

\#27.0406 Chemical preparations, n.e.c.

\#29.0201 Soap \& detergent

\#31.0101 Petroleum refining

\#4 of 38 Oil \& gas extraction

\#20 of 38 Motor vehicles

\#68.0100 Electric utilities

\#68.0200 Gas utilities

\#38 of 38 Households
1995 Data

(\$)

[3]

3.4530

2.8553

3.7935

2.9132

2.7296

2.3475

1.9443

3.2388

2.2404

2.6559

2.1796
1992 Data

(\$)

[4]
$[3] /[4]$

[5]

$3.4467 \quad 1.0018$

$2.8507 \quad 1.0016$

$3.7882 \quad 1.0014$

$2.9083 \quad 1.0017$

$2.7256 \quad 1.0015$

$2.3452 \quad 1.0010$

$1.9420 \quad 1.0012$

$3.2335 \quad 1.0016$

$2.2370 \quad 1.0015$

$2.6527 \quad 1.0012$

$2.1682 \quad 1.0053$ 
Table C2: Comparisons of Employment Multipliers Based on 1992 and 1995 Data, and 1987 Industry Structure

\begin{tabular}{|c|c|c|c|c|c|}
\hline \multirow[b]{3}{*}{ Code } & \multirow[b]{3}{*}{ Industry } & \multicolumn{3}{|c|}{ Final Demand Employment Multiplier } & \multirow[b]{3}{*}[3]{$/[5]$} \\
\hline & & 1995 Data & 1992 Data & 1992 Data & \\
\hline & & Jobs/MM95\$ & Jobs/MM92\$ & $\begin{array}{c}\text { Jobs/MM95\$ } \\
{[4] / 1.0751}\end{array}$ & \\
\hline$[1]$ & {$[2]$} & {$[3]$} & {$[4]$} & {$[5]$} & {$[6]$} \\
\hline \#1 of 38 & Farm products & 52.0 & 46.9 & 43.6 & 1.1920 \\
\hline \#2 of 38 & Forest products & 28.4 & 28.5 & 26.5 & 1.0713 \\
\hline$\# 14.2500$ & Soybean oil mills & 35.5 & 33.4 & 31.1 & 1.1427 \\
\hline \#27.0406 & Chemical preparations, n.e.c. & 21.6 & 23.7 & 22.0 & 0.9798 \\
\hline \#29.0201 & Soap \& detergent & 17.3 & 19.0 & 17.7 & 0.9789 \\
\hline \#31.0101 & Petroleum refining & 10.4 & 11.3 & 10.5 & 0.9895 \\
\hline \#4 of 38 & Oil \& gas extraction & 12.0 & 13.0 & 12.1 & 0.9924 \\
\hline$\# 20$ of 38 & Motor vehicles & 24.0 & 26.0 & 24.2 & 0.9924 \\
\hline \#68.0100 & Electric utilities & 14.4 & 15.8 & 14.7 & 0.9798 \\
\hline \#68.0200 & Gas utilities & 13.6 & 15.0 & 14.0 & 0.9748 \\
\hline \#38 of 38 & Households & 25.9 & 27.2 & 25.3 & 1.0237 \\
\hline
\end{tabular}

